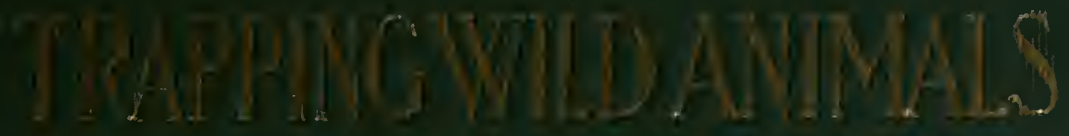

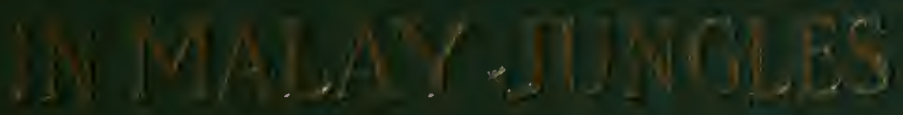

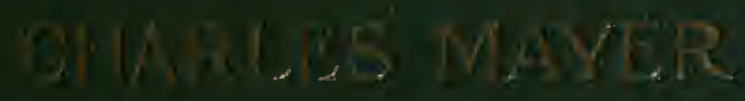

ia 
LIBRARY UNIVERSITY OF CALIF ORNIS SAN DIEGO 
Digitized by the Internet Archive in 2007 with funding from Microsoft Corporation 




\section{TRAPPING WILD ANIMALS IN MALAY JUNGLES}






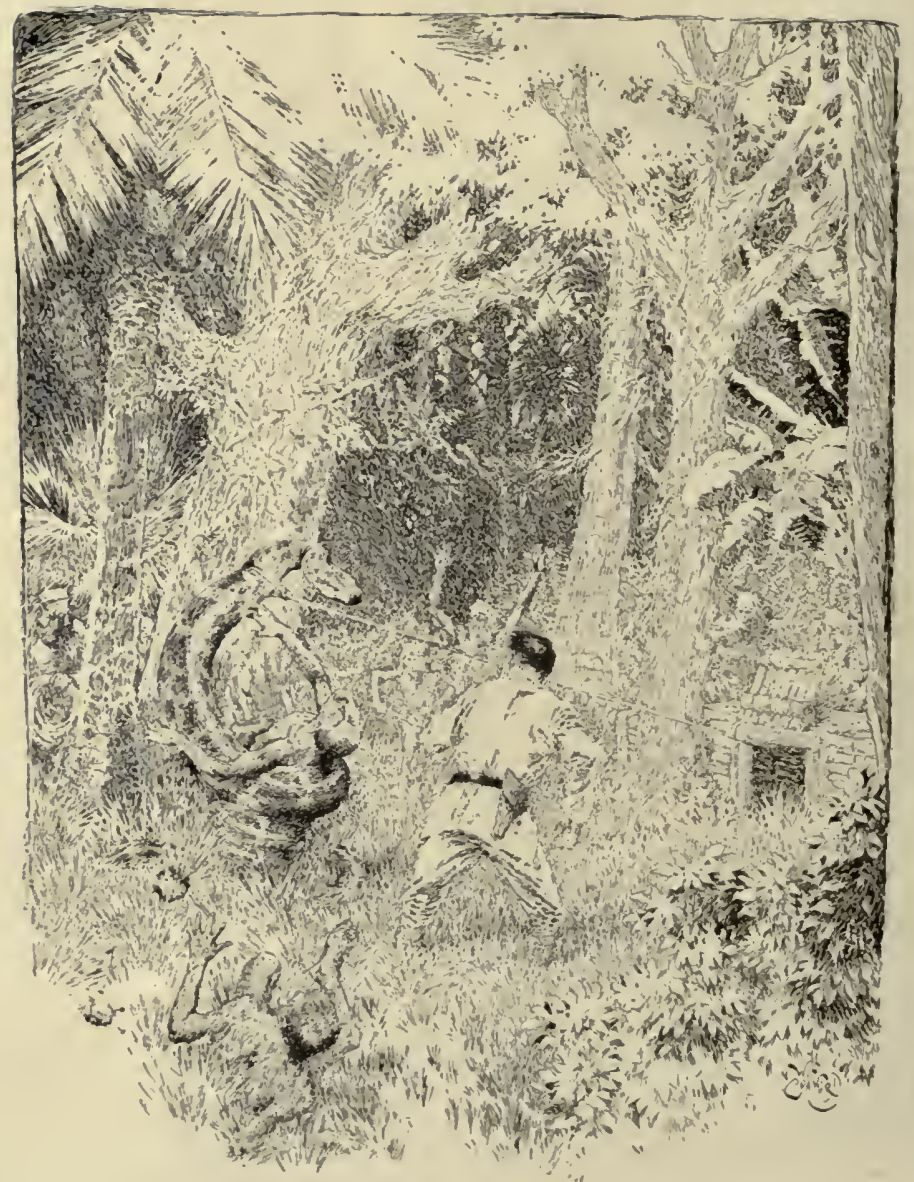

"The native screamed and the snake constricted suddenly. breaking nearly every bone in the man's body and crushing the life out of him." 


\title{
Trapping Wild Animals in Malay Jungles
}

\author{
BY \\ CHARLES MAYER
}

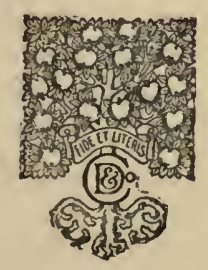

NEW YORK

DUFFIELD AND COMPANY

I92I 
Copyright, 1920, by Asia Publishing Company

Copyright, 1921, by

DUfField and CompanY

Printed in U. S. A. 


\section{To \\ MY SISTER DORA}





\section{CONTENTS}

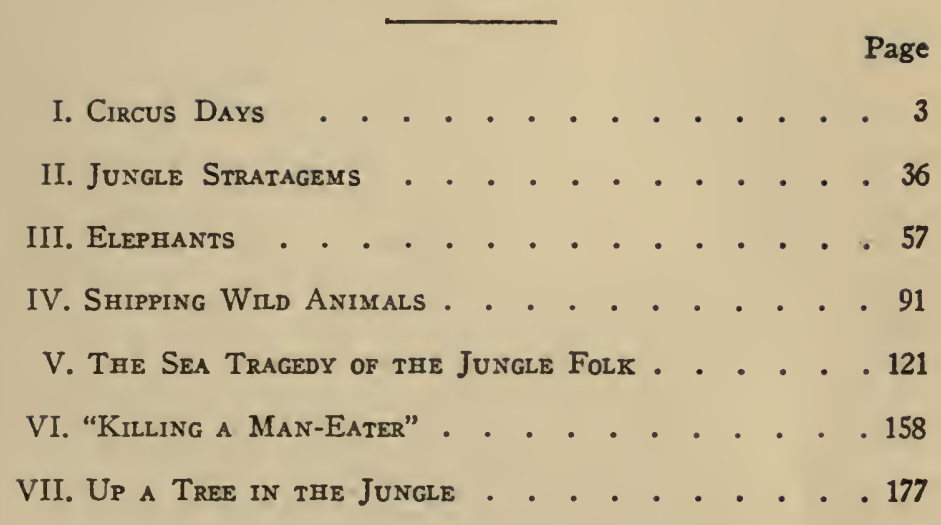




\section{ILLUSTRATIONS}

"The native screamed and the snake constricted suddenly, breaking nearly every bone in the man's body and crushing the life out of him." . . . . . . . Frontispiece

"I looked up just as a black leopard sprang at us. Ali's spear whizzed by my head, hitting the animal in the side. I fired, catching him in mid-air squarely in the chest with an explosive bullet." . . . . . . . . . Facing Page

"Since the monkey cannot pull his hand out of the bottle while it is doubled up and he hasn't sense enough to let go, he sticks there until the hunter comes along." . Facing Page

"I climbed to the platform and looked down into the trap. There were sixty elephants." . . . Facing Page

"I felt myself spinning so rapidly that the elephant, my men and the stall were all a blur; and I came up against the wall with a thud. Fortunately, there was a gutter running along the wall, and I dropped into it just as the elephant lunged forward at me." . . . . . . . Facing Page

"We began to prod the rhinoceros. . . . . He put his head against the wall and rooted; the wall toppled over and he lurched out of the pit and into the cage." Facing Page 115

"A huge paw shot out and grabbed my ankle. I was jerked off the ground, and, as I fell, my hands caught the limb of a tree. . . . The brute pulled. I felt myself growing dizzy. .... Then Omar grabbed a club and pounded the Orang's arm." . . . . . . . . . Facing Page 142

"Then three of us armed with krises took positions so that we should be above the seladang when he charged, and we lowered the sack. He snorted and drew back." 

TRAPPING WILD ANIMALS

IN MALAY JUNGLES 


\title{
Trapping Wild Animals in Malay Jungles
}

\author{
I \\ CIRCUS DAYS
}

$\mathbf{I}^{\mathrm{T}}$ was the lure of the circus-the tug that every boy feels when a show comes to town-that started me on my career as a collector of wild animals. I use the word collector rather than hunter, because hunting gives the idea of killing and, in my business, a dead animal is no animal at all. In fact, the mere hunting of the animals was simply the beginning of my work, and the task of capturing them uninjured was far more thrilling than standing at a distance and pulling a trigger. And then, when animals were safely in the net or. stockade, came the job of taking them back through the jungle to the port where they could be sold. It was often a case of continuous performance until I stood on the dock and saw the boats steam away with the cages aboard. And I wasn't too sure of the success of my expedition even then, because the animals I had yanked from the jungle might die before they reached their destination.

I was nearly seventeen when Sells Brothers' Circus came to Binghamton, New York, where I was 
living with my parents. That day I joined some other boys in playing hookey from school, and we earned our passes by carrying water for the animals. It wasn't my first circus, but it was the first time that I had ever worked around the animals and I was fascinated. I didn't miss the big show, but all the rest of the day I was in the menagerie, listening to the yarns of the keepers and doing as much of their work as they would allow. That night, when the circus left town, I stowed away in a wagon.

The next morning, in Elmira, I showed up at the menagerie bright and early. The men laughed when they saw me. I had expected them to be surprised and I was afraid that they might send me away, but I found out later that it was quite an ordinary thing for boys to run away from home and join the circus. And the men didn't mind because the boys were always glad to do their work for them. I worked hard and, in return, the men saw that I had something to eat. That night I stowed away again in the wagon.

In Buffalo I was told to see the boss-the head property-man-and I went, trembling for fear he was going to send me back home. Instead, he told me that I might have the job of property-boy, which would give me $\$ 25$ a month, my meals and a place to sleep-if I could find one. There were no sleeping accommodations for the canvas and property crews; we rolled up in the most comfortable places 
we could find, and we were always so dead tired that we didn't care much where we slept.

Since those early days in the circus, I've been around the world many times, and I've seen all sorts of men, living and working in all sorts of conditions, but I've never found a harder life than that of property-boy, unless, perhaps, it's that of a Malay prisoner. Sometimes I wonder how I stood it and why I liked it. But I did stand it and, what is more, I loved it so much that I persuaded the boss to keep me on when we went into winter quarters.

The moment we arrived at a town, the head canvas-man rode to the lot on which we were to show and laid it out; that is, he measured it and decided on the location of the tents. The men with him drove small stakes to indicate where the tentpegs were to be placed. In the meantime, the property gang unloaded the show. Then we drove the four-foot stakes for the dressing-tent into whatever kind of ground the lot happened to have. A man can work up a good appetite by swinging a fourteenpound hammer for an hour or so before breakfast, but before we started we had also many other things to do. The dressing-tent had to be spread and hoisted; then the properties were sorted and placed in their position for the performers to get ready for the parade. Meanwhile the canvas-gang was getting the "big-top" up. Then, when the parade started, we went to the "big-top" and arranged the properties there, made the rings, adjusted the guys, 
ropes and wires for the aerial acts and laid out all the paraphernalia for the ground acts. While we were doing these things, the canvas-men were stringing the seats. Then we had breakfast.

When the parade returned, there were cages to be placed in the menagerie tent and the parade properties to be prepared for shipping. By the time that work was finished, the crowds had arrived for the show and we stood by to handle the tackle of the various acts. At night, after the show had started, we began taking down the smaller tents and stowing the properties just as fast as they came from the "big top." Then, when the show was loaded, we took one last look over the lot to be sure that nothing had been left behind.

No, we didn't care much where we slept-just any spot where we dropped was good enough.

My greatest interest was in the animals, especially the elephants. In my spare minutes-they were mighty few and far between-I talked with the keepers and learned from them many things about the care of animals. When we went into winter quarters at Columbus, Ohio, the head animalman agreed to let me stay as a keeper.

The next season I went with the Adam Forepaugh show; then with the Frank Robbins show. I learned the circus business from the ground up and I was rapidly promoted. In I883, I joined $R$. W. Fryer's show as head property-man and transportation master. It was a responsible position, 
which required every bit of the knowledge I had gained in the few preceding years. I had charge of all the circus property and I was boss of a large crew of men. The job kept me on the jump day and night. The canvas and property crews were made up of the toughest characters I have ever struck in my life-a man had to be tough in those days. They were hard to handle, but they were good workers and I got along all right with them.

They were always just a little bit tougher than any local talent we came up against on the tour, even though a circus used to attract the worst men for miles around. At Albuquerque one night, four "bad men" came to see the show. When they came up, Fitzgerald, who was one of the partners, was taking tickets at the entrance. He tried to get tickets from them, but they pulled out guns. One of them said: "These are our tickets." Fitzgerald let them in and passed the word along to the crew. The men took seats and, when the show started, they let loose with their guns, shooting through the tents and letting a few bullets fly into the ring. Sometimes a bullet would strike near a performer, raising a puff of dust and scaring him half to death. The "bad men" were sitting with their legs dangling down between the seats. Some of the crew took seats near them, just as if they were part of the audience, and a dozen property-men sneaked under the tent. When the signal was given, they grabbed the dangling legs and pulled. Then the 
circus-men in the seats jumped up and, without letting the audience know what was happening, they snatched the guns. Down went the "bad men" between the seats. It all happened so quickly and so quietly that the audience didn't realize what had become of them. The canvas-men "toe-staked" them; that is, they hit them over the heads with the toestakes that are driven into the ground to keep the seat-stringers from sliding. A toe-stake is of just the proper size and weight to use in a fight, and it is the circus-man's idea of a good weapon. The crew buried the four men while the show was on. I thought there would be trouble before we could get out of town, but the men weren't even missed.

The Fryer outfit had a Pennsylvania Dutchman called Charley. $\mathrm{He}$ was one of the strongest men I have ever seen. One night, when the stake-wagon, drawn by eight horses, was stuck in the mire, he lifted the rear end of the wagon on his back while the horses pulled it out. I think that if Charley had got a good swing at a man and used his full strength, he could have killed him with one blow. One day, in Christchurch, New Zealand, while Fitzgerald was taking tickets, a larrikin-a toughcame along and said: "Ticket?-I'll spit in your eye." Fitzgerald knocked him down and called for Charley, who was working at the ticket-wagon. Charley took the larrikin in his arms just as easily as if he had been a baby, and carried him out into the street. There he dropped him and said: "If I 
have to do this again, I'll hit you." The larrikin didn't come back.

Charley's work at the ticket-wagon was to keep the crowd moving. In front of the ticket-window there was always stretched down a big sheet of canvas covered with sawdust. When a man put down his money for a ticket, the fellow in the wagon passed him out a ticket for the cheapest seat and charged him the highest price-unless the man showed that he knew exactly what seat he wanted; in that case, the ticket-seller shoved his change out so that one or two coins slid off the counter into the sawdust. If the man tried to stop and hunt in the sawdust for his money, Charley pushed him along to make room for the others who wanted to buy tickets. After the crowd had passed into the tent, Charley and his pal would take up the canvas and sort out the money from the sawdust.

I wasn't in on that "flam" system, but I had another way of making money. As head propertyman, I stood near the entrance to the "big-top" and, when people weren't satisfied with their seats, they came to me. I sold them the privilege of taking better seats. The sum acquired in this way was known as "cross-over money" and it was supposed to be turned over to the company. One day one of the partners objected to this arrangement. He decided that he would take the "cross-over money" himself and have me collect tickets at the main entrance. The other partner in the show would not 
agree to this scheme. "If Mayer takes the "crossover money"," he said, "we get half of it, at least; but, if you take it, we don't get any."

That settled the matter, and, considering times and ways, I've always thought that it was a good tribute to my honesty. It was a crude business and every man was out for himself. To break even, a man had to be just as hard as the next one, and to come out ahead, he had to be a bit harder. I liked the game, but I always had the feeling that it wasn't the thing I wanted most. I was interested chiefly in the animals, but, as head property-man, I had little time to be near them.

My desire to learn all there was to know about animals was the main reason why I cultivated the acquaintance and friendship of Gaylord. He was an expert animal-man-probably the best informed in the business-and had been P. T. Barnum's confidential agent for years. He had traveled the world over, time and again.

It was Gaylord who negotiated with the Siamese officials for one of the famous white elephants of Siam. Barnum had his heart set on having one of them for his show and he sent Gaylord out with instructions to go the limit. The stumbling-block in the transaction was that the Siamese believe the spirits of the ancestors of the royal family are transferred to the white elephants. The animals live in the royal palace and are cared for with all the ceremony given to any members of the reigning 
family. Of course, Barnum's plan was just as unthinkable to them as if he had offered to exhibit the king in his side-show. There was a hot exchange of cablegrams between Barnum in New York and Gaylord in Siam. Finally Barnum offered the government $\$ 250,000$ for the privilege of borrowing one of the elephants for just one year. $\mathrm{He}$ agreed to support a retinue of priests and attendants and to pay all transportation charges. The government would not even consider the proposition so Gaylord gave up in disgust and cabled that the deal was off. But Barnum was not discouraged. When Gaylord returned to this country, he found that the old man was advertising a white elephant from the royal palace of Siam. Barnum had simply used a whitewash brush on an ordinary elephant, with the result that he had a whiter elephant than the Siamese ever dreamed of seeing. The animal was so covered with velvet robes and surrounded by attendants that the audience could not detect the fraud; the general effect was good and the trick brought in a lot of money.

Gaylord was quite deaf when I knew him, and so was Fryer. Sometimes at rehearsal in the morning Fryer would come along and say to Gaylord: "Let's go up on the top seat-I want to tell you something privately." Then they would climb up to the top seats and exchange confidences-shouting at each other so loud that you could hear them all over the lot. 
The Fryer show opened in Kansas City and then worked right out to the coast. After a month in San Francisco, we jumped to Hawaii. We showed a month at Honolulu and the King rarely missed a performance. We had a royal box fitted up for him, and he had as good a time as any of the youngsters. From Honolulu we went to Auckland, New Zealand, where we found a twenty-day quarantine on all animals. We managed to get along by giving performances in the Theatre Royal-just the acts that required no animals. After that we went to Australia and showed at all the large towns; then we shipped to Java. Next we visited the Malay Peninsula, where later I was to spend many years in collecting animals.

During these long voyages, I spent much of the time with Gaylord, listening to his stories of experiences with animals. I had many questions to ask and Gaylord, whose fund of information was inexhaustible, always answered them and told me more besides.

A few days after we arrived at Singapore, he said: "Do you want to come with me while I buy some animals?" Naturally, I jumped at the chance. We went to the house of Mahommed Ariff, the Malay dealer who held a monopoly on the animal trade. He was squatted in the center of his courtyard, surrounded by cages containing the animals brought in from the jungle by his native agents. He was a wicked old devil and a man had only to glance 
at him to be convinced of the fact. His forebears, Gaylord told me as we were going to his house, were pirates, and he was the chief of a clique of Samgings (the native gangsters), composed of natives who would commit any crime he ordered. It was by using such methods that he held his monopoly of the animal business; the natives were afraid of him, and no European or native had dared to interfere with his trade. His head was shaven and his lips and chin were stained crimson from chewing betel-nut. He had little bullet eyes, set in a fat face. My impression of Mahommed Ariff was that he would be a bad man to have as an enemy, but it naturally didn't enter my head that he was to become a sworn enemy of mine a few years later. He greeted us cordially, for he had done business many times with Gaylord, and we sat down with him to talk animals. His religion was "to do all Europeans," but he could not help being honest with us. If any man knew the value of animals, it was Gaylord, and old Mahommed Ariff was well aware of the fact. That day we bought a tiger, several monkeys and a pair of leopards.

Several times during our stay in Singapore, I went to see Mahommed Ariff. He spoke a little English and he was usually willing to talk with me, hoping, perhaps, that we would buy more animals. From him I learned something of the work of collecting as it was done on the Malay Archipelago, 
but I had no idea, at that time, of entering the business.

The show moved to Penang; thence to Bangkok, Hongkong and Shanghai; then to Japan. It was in Tokyo that Gaylord had one of his bright ideas. He organized, in conjunction with the circus, a Japanese village, and, when we worked back over our route, via Singapore and Australia, we carried forty Japanese with us. Twelve of them were performers and the remainder were artisans. We had miniature Japanese houses, in which the artisans worked at their trades, such as fan-making, wood-carving and embroidering. Also we carried a big stock of cheap Japanese goods, which were sold as the products of our traveling factory. The Japanese village was a great success and brought a lot of money into the show.

In September, I886, we struck Buenos Aires, where the show had to buck the Carlos Brothersthe big South American outfit-and bad weather. During the long tour we had overcome many obstacles, but that combination was too much. Fryer, Gaylord and Fitzgerald decided to disband, and most of the properties and animals were sold to the Carlos Brothers.

By hard work and careful saving, I had managed to accumulate over $\$ 8,000$; so I was happy to head northward. I returned to New York by way of London and in December I met Fitzgerald. A short time afterward we were in St. Louis, where 
we bought the Walter L. Main show, which consisted of nothing more than a tent and some seats. We had no animals but we hired performers and started out on the road.

For one week we had luck and took in money; then came nine days of rain. The tent absorbed tons of water, and we had no way of drying it and preventing mildew. It was so heavy that the canvas-man could scarcely handle it.

At Springfield I went out to the lot and found Fitzgerald there; he just stood there, looking at the wet canvas spread out on the ground with the rain beating down on it. The canvas-men had given up - the tent was too heavy to hoist. That was the end of my only adventure as a circus-owner.

The big shows carried an extra tent to meet emergencies, but we couldn't have one, of course. The rain had beaten us to a finish. Even if we could have raised our tent, we should have had no audience, and we weren't well enough supplied with money to follow Bailey's idea of giving a performance if there were only two persons there to see it. Our "Greatest Show in the World" was sunk in an Illinois mud-puddle.

In later years I have stood sponsor for many of the shows and small circuses that visited Singapore. One I well remember belonged to an old friend, A. Bert Wilison of Sydney, Australia, who had been with the advance at the time I was with R. W. Fryer's Circus. He came with his show from Cal- 
cutta in pawn, that is to say, he paid as much as he had and the steamship company took a lien on his show or chattels, and if the agent at the port of disembarkment was satisfied, he could put up his tent and show, the steamship agent taking the receipts with interest until the freight and passage money was collected. I happened to be in Singapore at the time and was told a circus had just arrived from Calcutta_-Bert Wilison's African Circus and Equine Paradox." I was wondering who's it could be, as I had never heard of my old friend's rise to proprietor of a show.

I made up my mind to see him, if not for business then as an old showman, never dreaming I was to meet an old friend. The surprise and pleasure was mutual at our meeting, after an absence of nearly fourteen years. The last time we were together was in Buenos Ayres. As I was dressed in an old suit of khaki, I looked to him as if I were stranded. "Well, Charley," he said, "I'm broke, too, but I'll manage to fix you somehow and get you out of here. You come with me, old boy, we'll share what's left of the old show."

I thanked him and said that I was not as badly off as I appeared, but had been in the animal business for a number of years, was settled and pretty well known in Singapore, and if I could be of assistance to him, it was his for the asking.

"Well, Mayer, to tell the truth, I'm in hock with the steamship people. I have not enough to pay 
for the hauling of my stuff or feed for the horses, let alone to put my wife and child at a decent hotel."

I assured him I would see him through. There were tears in his eyes as he grasped my hand. I went with him to the agent of the British India Company and arranged for the payment of his passage and freight, in fact took care of everything for him. It made me feel good to be again in touch with the old show business; once in it, one never forgets its glamor. I arranged for the lot and feed for the horses, but the performers paid their own hotel expenses. We had still to look for the labor, so I hired coolies, and by night had the top up. At the same time there was a stranded balloonist whom I was befriending, an American named Price, who went broke in India. He had his balloon, which wanted but a little repairing, so I made arrangements with Wilison for Price to join the show and give ascensions and parachute jumps for an attraction.

Well, the show opened and made good. The balloon ascension was something new and it went big, especially when the balloon was anchored and would take people up. Wilison played Singapore two weeks, paid all his debts and was on his feet. I advised him to play Bankok, and, if possible, get a guarantee from Prince Damvony to show inside the palace, which he did with success. The only thing that marred the career of the show was when Price went up in the balloon and took a parachute 
jump, he drifted down into the King's household, that is, the women's pavilion, and caused an awful uproar among the inmates. He had to do a lot of explaining to convince the officials that it was no fault of his, that it was unavoidable, as the wind carried him there. I leave my readers to imagine, if they can, the fright and feeling of the women on seeing a man, a European, dressed in tights, dropping amongst them from the skies. It was weeks before the scare wore off, and it was spoken of for years after. The last I heard of Wilison was in Japan, when he intended to go from there to Hawaii and then to Australia.

As the steamer having the Wilison show aboard left the docks, the old fascination of show life seemed to grip me. It brought back wonderful memories of the good old days when one-ring circuses were the real thing. I look back on those days with regret, days when I was the head or Boss Property Man, for next to the Proprietor the Boss Property Man was king of the dressingtents, and woe to the performer who slighted him. When the Show would make its first start on the road, the Boss Property Man would place the performers' trunks in position. Pay day, the performer who neglected to give his fifty cents or dollar to the Boss Property Man, would find his trunk badly damaged, broken open or no trunk at all on arrival at the next town. It was a custom that few ventured to neglect, for otherwise they 
might suffer the loss of their wardrobe or part of it, and probably their trunk, and ran the risk of being fired by the management for failure to be ready for their act.

One case in particular I remember when I was with the R. W. Fryer's Shows as Boss Property Man and transportation master. While the Show was still in Sydney, N. S. W., and a week before ending our eight weeks' stay, I told one of the performers, the bearer of a brother act, that is the man that holds the other man on his shoulders and catches him as he jumps or turns somersaults, to get a new trunk as he had an old tin-covered one that had the edges all worn and broken, and every time any of my men handled it they were sure to have their hands or clothes cut and torn. He promised to get one in Melbourne. We played Melbourne eight weeks and went from there to Ballarat, Victoria. He still failed to get a new trunk, and when the Show appeared in Ballarat, his trunk was amongst the missing, dropped or fallen off the train en route during the night. He was fired, and a day or so after got notice from the Government Railroad to come and get some of his belongings that had been picked up along the line. He got a new trunk.

Another character with the same Show was the Musical Clown, named Shilleto, a really good fellow, but seldom sober. I honestly believe that if he were sober he could not do his act. He was a 
natural born musician. He could pldy any instrument and play it well.

On arriving at any town, as a joke we would pick some one who had a local reputation as a ne'er-do-well and explain to him Shilleto's weakness, flattery and whiskey, telling him to go up to Shilleto and say, "I beg your pardon, but are you not Shilleto, the great Musical Clown, now with Fryer's American Show. I have seen you a number of times in different parts of Europe but never expected to have the pleasure of seeing you in Australia. You are the greatest I ever saw. Will you allow me to shake hands with you." Shilleto never had been in Europe, although it was his boast that he had traveled all over that continent with shows.

That would settle it. Shilleto's chest would swell up and that person was his guest for days, introduced as his friend, from Europe, often giving him a title. Shilleto never seemed to get wise to the fact that in every town he would meet with some one who had seen him in Europe and with the same story.

It was on one of the visits to New York that the late J. A. Bailey of Barnum and Bailey, sent me a telegram from Chicago to meet him two days later in New York, and, after mutual greetings, asked me how long it would take me to get to India. I told him I intended to stop two weeks in New York and probably three or four weeks in 
London. "Now, Mayer," he said, "I want you to get to India as soon as possible. Can you start tomorrow?" Tomorrow being a Saturday, I told him no, and then asked why the hurry. What was there in India that was wanted. He then told me that he had reliable information of a huge elephant, one standing fourteen to fourteen and a half feet high, in Bombay. I laughed, saying, "Mr. Bailey, your informant must be mistaken, there are no elephants in Bombay outside of government elephants, and I am sure none of them equal or come near that size." I assured him that I was fairly posted on the size of elephants in captivity throughout India, and reminded him of my standing order from him to secure if possible any elephant of twelve feet or over.

Now the elephant Jumbo was an African elephant and stood eleven feet two inches, and he was thought to be the tallest elephant in captivity, and when Mr. Bailey told me of an Asiatic elephant fourteen to fourteen and a half feet in height, I could not help smiling. "Mr. Bailey," I said, "why not cable to the American Consul at Bombay and have him secure it for you while your representative is on his way." No, he wanted me to start at once, as he said the Ringling Brothers and several others had heard of it and were sending men out, so he wanted me to beat them to it if possible. Money was no object as long as I was able to secure it, and as he was absolutely in earnest, I 
told him I could start the following Wednesday, July third. He asked me to see what connections I could make, to secure my passage for the following Wednesday and find out the shortest possible time I could make Bombay.

Can my readers form an idea what an Asiatic elephant fourteen to fourteen and a half feet high, and probably weighing from seven to eight tons, would mean to a circus like the Barnum and Bailey Show? What a drawing power it would be! It would mean a million or more. No keener or more wonderful manager than Mr. Bailey lived, but, like many others, was often misled by wonderful tales of strange things. Immense amounts of money were spent in searching for and trying to secure freaks and abnormal animals that never existed outside the minds of the showmen's informants.

As I said, money was no object. Get it! That was all there was to it. "Go get it!" sounds easy, eh?

After looking up the sailings from London to Bombay, I saw that one of the P. \& O. steamers leaving London on the fourth day of July was due in Bombay on the twenty-eighth day of that month, and told Mr. Bailey that if I left New York on the third of July, with luck, I would be in Bombay on the twenty-eighth.

"Can you make it, Mayer? By gosh, that's good time, but how are you going to do it? You have got to go to London first." 
I said that was true. I would leave New York on the third and catch the steamer leaving London on the fourth of July at Brindisi, at the tail end of Italy, as it was due there on the fourteenth.

I left New York on the steamer New York on the third, arrived in London on the tenth, stayed two days in London, traveled overland through France, Switzerland and Italy, and on the evening of the fourteenth walked up the gangplank of the P. \& O. boat and the twenty-eighth day of July, after transhipping at Aden, stepped ashore in Bombay.

Well, there was no such elephant; nobody had ever heard of any that size, let alone seen one neair it, either in Bombay or throughout India, and I went through India looking for it. The largest I ever saw belonged to the Maharajah of Mysore. He was, as nearly as I could judge, about twelve feet, but a bad one and old, always heavily chained, and out of the question for show purposes.

After I left Singapore, I had been thinking constantly of becoming a dealer in animals. The more I considered the idea, the more it appealed to me. I was becoming tired of circus life, especially since my work did not bring me into contact with the animals. On my return to New York I found Gaylord and told him about my plans. He encouraged me and introduced me to many men I was glad to know, such as Donald Burns, who was a dealer and had a store in Roosevelt Street. 
At Donald Burns's place I talked my venture over with many showmen. They were all interested and wished to encourage me, but they were frankly doubtful of my success because they knew of old Mahommed Ariff's monopoly. Burns offered to help me dispose of the animals, but I was not elated at that prospect, for Burns did not attend very strictly to business. It was a well-known story in the circus world that he had neglected the opportunity of handling the first hippopotamus brought to this country. A sea captain had offered to sell it to him for $\$ 3,000$, but Burns refused to take ithe simply wasn't interested. A few days later it was sold to Barnum for \$10,000.

Strangely enough, it was Burns's easygoing way of managing his affairs that gave me my opportunity of going to Singapore. I had been in New York, making my plans and saving my money, but I didn't feel that I had enough to start out on the venture. One day I was in Burns's store when he was away, and a sailor came in, hiding two monkeys under his coat. He had smuggled them into the country and wanted to sell them. The monkeys were black with coal-dust, but one of them, I noticed, had pink eyes. That fact interested me and I bargained for them, buying the pair for fifteen dollars. When the sailor left, I found a cake of soap and gave them a bath. The monkey with the pink eyes turned out to be pure white. Those were the days when Jim Corbett was a great favorite, and he had recently 
become known as "Pompadour Jim." My white monkey had a perfect pompadour on his head. Soon one of the newspapers printed a story connecting Corbett and the monkey. A few days later I sold the monkey for $\$ I, 500$, and I then had enough money to start for Singapore.

It was in April, I887, that I left New York on the steamer Glenderrie. I outfitted in London while we lay over there, taking cargo aboard, and, because I was none too sure what material I should need, I confined my outfit to clothes and guns. On the advice of several animal-men, I bought a Winchester 5O-IIO express rifle that fired explosive bullets. The bullets contained a detonator and enough dynamite to stop any animal in his tracks. My revolvers were a Colt .45 and a Smith and Wesson $\cdot 38$. The passage took seven weeks and during that time I became well acquainted with Captain Angus, who commanded the boat.

When I reached Singapore, I began at once to learn the Malay language, which is spoken with some variations of dialect throughout the Archipelago.

I called on Mahommed Ariff every day and learned as much as possible about the ways and means by which he carried on his business. Eventually I proposed to him that he let me act as his agent in interviewing the captains of some of the boats that called at the port. He agreed to my plan because there were many captains who would 
no longer do business with him-he had cheated them once too often-and he saw in me a means of resuming trade. We had no written agreement and no understanding as to my commission, but I was content to start work on that basis because it meant experience.

It was customary for the members of the crew of a boat to buy animals, splitting the risk between them, and sell them when they reached European or American ports. Soon after I had reached the agreement with Mahommed Ariff, a German boat came into port and I went out to interview the captain. I found that he had had previous dealings with the Malay and that he had sworn never to buy another animal from him. Finally, he agreed to make some purchases, but he took care to draw up a paper in which he said that he was buying on my representation.

I reported the deal to Mahommed Ariff, but when I went the next morning to deliver the animals, I found that he had sent them to the boat during the night and had collected the money for them. He refused to give me my commission because, he said, the captain was an old customer of his. The boat was about to sail and there was no time to get the captain ashore and settle the dispute. However, I had the written statement signed by him, that the animals had been bought from me, and I surprised Mahommed Ariff by suing him. He was a surprised Malay when I produced the paper in court, and he 
paid the commission and costs. The result of the suit was that I gained a number of friends and established a reputation.

For the time being, all deals with Mahommed Ariff were off, of course, and so I had to look elsewhere for business. I induced a Malay hadji, who had made a pilgrimage to Mecca, to take me to his home at Palembang, in the island of Sumatra. He was a buyer of animals from the people of his district and, as he did much of his selling through Mahommed Ariff, he hesitated at taking me with him. But I pointed out the advisability of having a European agent-all white men were considered Europeans. The vision of securing more business, without being robbed constantly by Mahommed Ariff, brought him around to my proposition, and we went together to the Dutch General in Singapore. I told the Consul General my plans, and, after I had presented references from the bank, he gave me a passport and a personal letter to the Dutch Resident at Palembang. Then the old hadji and I started off for Sumatra.

This was really my start in the business of animal collecting. At Singapore I had seen enough to know that the work I wanted to do was not simply to sell the animals at a port, but to capture them in the jungle. My main object in going to Sumatra was to live with the natives and learn their methods and language, so that, being at the source of the supply of animals, I could capture and sell 
with practically no interference from Mahommed Ariff. I was in constant communication with Gaylord, who encouraged me in my idea of becoming a collector; also I put myself in touch with the Australian Zoological Society.

The district in which the hadji lived had a population of about 100,000 , made up of Dutch, Malays and Chinese. Back of the settlement lay the jungle; a dense virgin forest of trees that were bound together by a woven mass of creepers and vines. The trunks, rising straight and smooth for fifty or sixty feet, burst into foliage that formed a thick, green canopy, through which the sun rarely filtered. On the ground, the vines, palm ferns, tall grasses and rattan made a wall that only parangs, the native knives, cutting foot by foot, could penetrate. The heat of the open spaces in the tropics is blistering, but that of the jungle is damp and stifling; moisture accumulates, and the light breezes that blow overhead have no chance of moving the air below, which is filled with the smell of rotting vegetation. Especially in the morning, before the sun has a chance to bake the water out, it is a drenching business to go into the jungle.

Notwithstanding the climate, the sight of such country made me anxious to begin work, and I lost no time in reporting to the Dutch Resident. The Dutch are strict in their colonial government, and, for the most part, they have good reason to be strict. One white man who does not understand the natives 
and who has no consideration for them may start trouble that will end in an uprising. The trouble generally comes from a lack of regard for the native's feeling for his women. Though the Malays live a fairly loose life, they resent having a white man take their women and they generally vent their displeasure in murder. That, of course, means a government investigation, with ill-feeling rising on both sides. To the Dutch Resident I explained my purpose in wishing to live in the Malay quarter with the hadji, and he gave me permission, warning me that it would be revoked at the least sign of trouble.

Thereupon, with the hadji leading, I took my belongings to his house and setiled down to become acquainted with the people. They regarded me curiously, but when the hadji introduced me by saying "E-tu-truan banyar bye. Dare be-tole (This man is very good. He is true)," they accepted me without question. The word of a man who has made a pilgrimage to Mecca is not to be doubted and my dispute with Mahommed Ariff was told and retold until it became a wonderfully exaggerated legend with me as the hero. They disliked Ariff because he was forever swindling them when they captured animals.

It is not difficult to win the friendship of the natives, if you know how to treat them. If they like you, they become doglike in their devotion; they will do anything you tell them to do and believe 
whatever you say as though it were gospel. I studied them closely, learning their language and customs and carefully avoiding anything that might bring me into disfavor. Day after day, I went with them into the jungle, picking up bits of junglecraft. Gradually I learned to see the things that they saw in the walls of green about us, and to interpret the sounds-the hum of insects, the call of birds, the chattering of monkeys and the cries of other animals-and I spent hours with them, squatting in their houses, busy with the rudiments of the Malay language.

Once during the eighteen months I spent with the hadji, I was haled before the Resident for an investigation, but the natives stuck by me valiantly and I was exonerated. The trouble started one evening when I was sitting on the hadji's veranda. There came a scream from one of the houses, and a native emerged, howling and swinging a knife, slashing at every one within reach-men, women and children. He was running amok, a victim of the strange homicidal mania fairly common among the Malays. When a man runs amok, he suddenly begins to kill and he does not care whom-his own family or people he has never seen before. The hadji yelled to me to shoot. I pulled out my revolver and fired, hitting the man in the left arm. He stopped for a moment; the other natives seized him and stabbed him to death. At the investigation, the hadji explained to the Resident that I was not 
responsible for the man's death and that I had acted on his suggestion, to save the lives of the natives. As the man had slashed about eight people before I shot, the Resident ended his investigation by thanking me and renewing my permission to live in the Malay quarter. I returned to the hadji's house more popular with the natives than ever before.

A native came running to the hadji's house one day with the news that he had seen a big snake. He said that it was at least fifty feet long and as big as a tree. Knowing the Malay habit of exaggerating, I put it down as about twenty feet long; but I gathered a crew of natives and we built a crate from the limbs of trees and bamboo, binding it together with green rattan. According to the native's tale, the snake had just swallowed a pig, and so, knowing that where he had first been seen, he would remain, sleeping and digesting his meal, we postponed the capture until the next morning.

A python always kills his food by coiling around it and crushing it to death; then he swallows it whole, slobbering so that it will pass his throat. During the digestive process, he generally becomes torpid and, without putting up much fight, submits to capture.

Before we went out for the snake, I told each man what he was to do, explaining carefully how I intended to get the snake into the crate. When I was sure that they understood, we started into the 
jungle, led by the native who made the discovery. I was surprised to find the largest snake I had ever seen. It looked at least thirty feet long and about eighteen inches in diameter. For a moment we stood there gasping.

The python was sleeping peacefully, digesting the pig. I called to the men and put them to work at staking the crate to the ground and securing it so that the snake could not lash it around. The crate was about eight feet long, six feet wide and two and one-half feet deep; just large enough to hold him and just small enough so that, once inside, he would not be able to get leverage and break it. Again I explained what each man was to do. Then I passed a rope through the crate, tying one end to a tree and preparing a running noose to be slipped around the snake's head when we were ready to draw him forward. Two more ropes were laid out, running from his tail. These we wrapped around trees on each side of the tail, and I stationed men at the ends, showing them how they were to pay out the rope as the snake was drawn toward the crate, keeping it taut enough to prevent him from lashing.

The python slept soundly through all these preparations. When we were ready, I gathered the men about me and cautioned them against becoming excited. I warned all those who had not been given work to do to stand back out of the way and not to approach unless we needed them. 
With bamboo poles we prodded the snake at the head and tail, standing by with the nooses, ready to slip them on when he stirred sufficiently. Before he realized what was happening, we had the headnoose over him. The instant he felt the rope tighten he was awake!

The natives holding the tail-ropes became excited and succeeded in getting only one of them in place. The python suddenly leaped forward, and, though he did not loosen the rope, whipped it out of the hands of the men and knocked several of them flat; then he caught one man, who had not been able to get out of the way, and wrapped the lower part of his body around him while five or six feet of his tail still lashed about with the rope. I yelled to the others to pull on the tail-rope, but the confusion was so great that they did not hear me. I went for the snake's neck, which is the most tender part of him, hoping to sink my fingers in on the nerve center and disable him for a moment until the men collected their senses and pulled the rope. By jumping forward, the snake had loosened the head-rope sufficiently to turn on me and sink his fangs into my forearm. I sprang back.

The man who was caught in the snake's coils screamed, and tried to beat off the tail as it was drawing in about him. Then the snake constricted suddenly, breaking nearly every bone in the man's body and crushing the life out of him instantly. Blood spouted from his mouth and ears, and he was 
thrown limply about as the snake lashed the air.

I yelled to the men to pull the head-rope taut. Fortunately, the tail-rope had not become loose, and we caught it just as the snake tried to lurch forward again. We allowed him to move forward slowly, drawing his head toward the crate and, at the same time, holding his tail until we had him stretched out. By prodding his tail with sticks, we forced him to uncoil and to release the body of the native.

The head-noose had been slipped farther down than I wanted, and was giving his head too much play. Assuring the men that he could do no more harm, I took three of them with me and we grabbed the snake's neck. He tossed us about, and we had several minutes of exciting work before we got the head into the open end of the crate. When the rope was secured, we fastened another rope about the middle of him.

The snake lashed furiously, knocking several of the natives down. Stationing a crew of men at the tail-rope to slacken it as we moved forward, I took the others to the crate and set them at pulling on the middle rope. As we dragged the python forward, he coiled in the crate; then, when he was half in, we secured the middle rope and head-rope to trees, passed the tail-rope through the crate and dragged the tail in. There was great rejoicing when we closed the end of the crate and prepared to haul it back to Palembang. We had captured a 
prize specimen. Cross of Liverpool, to whom I sold him, told me that he measured thirty-two feet. I have never seen his equal in length and girth. But, huge as he was, he coiled up comfortably in his small quarters, promptly fell asleep and went on digesting his pig. 


\section{II \\ JUNGLE STRATAGEMS}

THE entire population of Palembang came to marvel at the size of the python, and, before I realized it, I had acquired a wonderful and widespread reputation as a collector. I was soon besieged by requests to go out and capture all kinds of enormous animals-most of them imaginary, of course, for a Malay can imagine anything. Once he starts with "Sahya fikir (I think)," you may expect to hear many wonderful tales if you have time to stop and listen to him.

To Malays nothing seems impossible, and it is difficult to hold them down to actual facts. They will hedge about with "I think" and "bârang-kâli (perhaps)" until you give up in disgust; and then they will offer to bring their brothers or other relatives, who will repeat the performance. Sometimes I used to spend hours in wondering how their minds worked, and I came to the conclusion that they talk merely with a desire to please. They want to tell anything you want to hear, regardless of whether it is true or not. It is exasperating and occasionally funny. For instance, several years after I left Sumatra, I was traveling through the jungle, looking for elephants. At one village I talked with the 


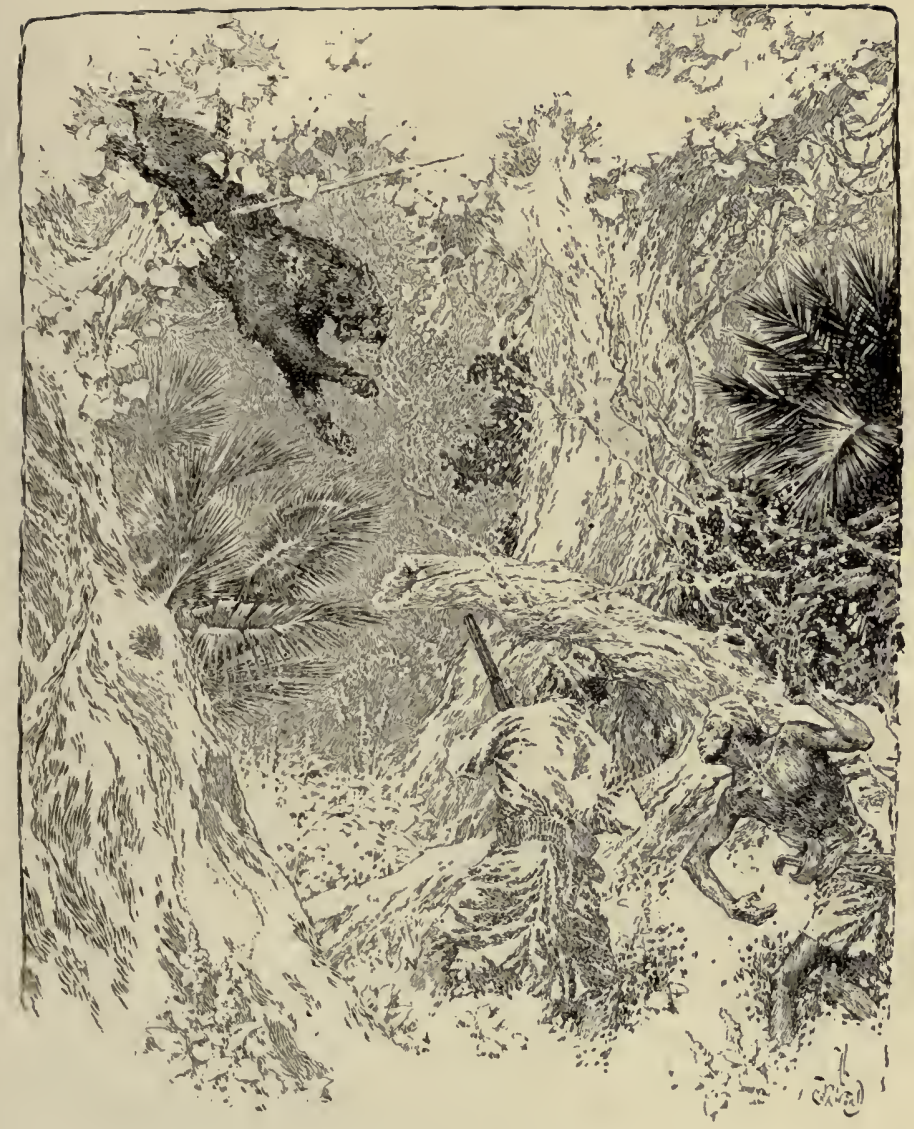

"[ looked up just as a black leopard sprang at us. Ali's spear whizzed by my head, hitting the animal in the side. I fired, catching him in mid-air squarely in the chest with an explosive bullet." 

Malay headman, who represented the government in that locality, and the conversation turned to large elephants. Jumbo, who was eleven feet two inches, had died, and I had it in my mind that I should like to find an animal big enough to take his place. "Have you ever seen a twelve-foot elephant?" I asked the headman. And as quick as a flash, he answered, "How many do you want?" $\mathrm{He}$ could not understand why I rolled back on the floor and laughed until my jaws ached. The headman was a true Malay.

I found it best, in trying to get information from a Malay, to ask my question and then, before he had a chance to speak, say: "Jângan fîkir-jawâb ya tîdak. Sahya bûlih fîkir. (Don't think-answer yes or no. I'll do the thinking)." Then he would generally admit immediately that he didn't know, but he would always offer to bring his brother or some other person that he thought might know. It is a trait that makes business relations between the whites and the natives difficult, and is to a large degree responsible for the fact that much of the business in the Archipelago is done through the Chinese. The Chinese have sufficient patience and understanding to deal with the Malays, and they know how to make them work.

There are two distinct classes of Malay: the Orang Ulu, living in the jungle, and the Orang Laut, living on the coast. Through their association with the Chinese merchants, some of the latter 
develop into clever dealers, but for the most part they are content to spend their lives in loafing. They work when they need money, but they need so little of it that they can afford to idle along through life. When the supply of food runs low, they put out in their boats at daybreak and return at sundown with fish. These are sorted and left to dry, afterward sorted again, according to their market value, and sold to the Chinese, who ship them in palm-leaf baskets to Singapore. Then the Malays have finished their work for another month or so. Often the merchant advances money for future delivery, and the Malays find themselves obliged to work for long periods to keep from being punished for debt. That is a favorite method of making them work. They consider themselves gentlemen and despise the Chinese as pig-eating heathens. If they must submit to working for the Chinese merchants, they have the satisfaction of watching the coolies do most of the hard labor while they spend their days at games.

The day's routine while I stayed in Palembang with the old hadji was simple and pleasant. I lived with him and his first wife-he had three others. We rose early and went for a swim in the river, and then, squatting on the floor and eating with our fingers, we breakfasted on fish and rice. After breakfast, the hadji and I would stretch out on our mats and smoke and talk until my servant came to prepare my lunch. A Malay eats but two meals 
a day-always rice and fish-but I found that two weren't enough for me. After lunch I slept through the heat of the day, with the thermometer climbing up to about $125^{\circ}$. Then, when evening came, Palembang stirred into life.

The Malays liked games and they were continually after me to show them some new kind of kindergarten pastime. It made no difference whether it was tag or diving into buckets of treacle after money; if it was a game, they liked it. Some of them knew how to play chess and they gave whole days and nights to it. They are especially fond of gambling, and they repeatedly lose all their money and borrow from the kind merchant, with the result that, to make good their debts, they spend weeks in fishing.

Occasionally I went to the Dutch quarter to seek a few hours of companionship with white people, but I got little satisfaction out of these visits because I could speak better Malay than Dutch, and at Palambang there were few people who knew English. The white people could not understand why I preferred living with the natives, and some of them looked down on me for it. However, that fact did not trouble me, because I knew what I wanted and I was on the way to getting it. With the hadji I learned the Malay language rapidly, and before long I knew the natives far better than the average white man who goes to work in the Archipelago. For the most part, the whites make no 
effort to understand them and are thus largely responsible for the troubles that arise. In recent years, the attitude of the colonial governments has changed for the better and there have been fewer disturbances.

The natives came to have confidence in me, especially after the capture of the python, and accepted me as a friend. Often during the evening, when the hadji and I sat talking on the veranda, thirty or forty natives would squat near us, listening to the conversation. If the hadji or I cracked a joke, they would laugh uproariously-not that they understood what had been said, but simply because they wanted to do the proper thing.

The hadji's nephew, Ali, became my devoted servant. He was about twenty years old and far more intelligent than the average; also he was brave and resourceful-qualities that made him my most valuable aid until he was killed during one of our expeditions several years later.

When I went to Singapore with the python, I took Ali with me, and for weeks after, he entertained the natives of Palembang-and me-with his stories of what he had seen and done. It was an excellent example of the feats that Malay imagination can perform.

In Singapore I found an agent of Cross, of Liverpool, of whom I have spoken, and sold the snake to him for $\$ 300$ (Mexican), which was considered a banner price. I was glad to have the opportunity 
of making myself known to the agent, because I foresaw future commissions. He, like many others, was tired of doing business with Mahommed Ariff, who took every possible advantage of his customers, and he was pleased to find a white man in the field of collecting.

We re-crated the python and shipped him off to Liverpool, after feeding him twelve ducks each day for five days. With that stomachful, he could last out the entire voyage and arrive in England with a good appetite.

It was difficult to get the Malays from the coast to go up into the jungle. They fear it and have superstitions about the hantu that live there. Most of the men refused point-blank when I asked them to accompany me, and others thought of various things they had to do at Palembang. Ali was willing, however, and he developed into an expert jungle-man. Boatmen from the coast poled us up the rivers, but they returned to the coast immediately because they were unwilling to remain away from their families.

It was after my return to Palembang that $I$ became acquainted with the inland of Sumatra and with the Orang Ulu, who are quite different from their brothers on the coast. They are more industrious and have not lost their simplicity and honesty by coming into contact with Chinese business methods. They received us kindly and I had no difficulty in making friends with them. During the 
next year I spent much of my time inland, in hunting and fishing, and I discovered that Sumatra was not the field for collecting that I had expected it to be. But it served my purposes of learning the language and becoming acquainted with the people quite as well as any other part of the Archipelago would have done; and I was too busy studying jungle-craft from the Orang Ulu to think of leaving. Ali, who was always with me, was an invaluable aid. He was a first-rate spear-thrower, but he wanted to be a good shot. He took great pride in my 50-I Io express gun, which he carried behind me. He had a trait peculiar in Malays-he was always busy. And he spent a great deal of his energy in cleaning and polishing the gun, hoping for the great reward of being allowed to shoot it. Eventually he became a good marksman. The other servant who accompanied me on my trips into the jungle was a Chinese coolie. He had been my rickshaw boy and I promoted him to the position of cook and store-keeper. Ali was intensely jealous of him but they worked well together.

Though the natives made a sport of spear-throwing, they had given over that method of hunting. They were armed with guns that I honestly believe dated back to Revolutionary times-old, muzzleloading flintlocks. Where they got them I have never been able to discover. They were fascinated by my 50-IIO, of course, and, when Ali cleaned it, they squatted about him, wide-eyed. Whenever I 
saw a native about to shoot his old muzzle-loader, I yelled to him to wait until I got well behind, because the thing sometimes exploded. It was a wonder to me that it didn't always explode. Except when he was after small game, a native loaded his gun nearly to the end of the muzzle with powder before putting in the wads and a huge slug of metal. When he pulled the trigger, he closed his eyes and flinched because the recoil always knocked him flat. But he expected that and cheerfully picked himself up from the ground with the question, "Did I hit it ?" And often he did hit it-if the barrel did not explode. I have seen some of the natives with ordinary iron pipe fitted on their guns to replace the barrels that had not been able to stand the strain.

I learned in the jungle that the hunter must always be on the lookout for the unexpected. At first it was difficult for me to distinguish between all the sights and sounds and to interpret each of them, but I soon learned under the tuition of the natives. One great danger came from the leopards, both spotted and black, who lie along the limbs of trees and spring without warning. A tiger slinks away when disturbed in the daytime, but a leopard almost always stands his ground and springs as one passes beneath him. And he can do more biting and scratching in one minute than a tiger can in three or four minutes.

Ali's alertness saved me one day from a terrible 
mauling, if not from death. We were breaking through the jungle on our way to some traps; Ali shouted and pushed me to one side, shoving my gun into my hands. I looked up, setting my gun, just as a black leopard sprang. Ali's spear whizzed by my head, I fired, catching the animal in mid-air squarely in the chest with an explosive bullet. Ali's spear hit him in the side. I took it as a good lesson in carefulness. It was well enough to be on the alert for the animal I was trailing, but it was'also important to be on the alert for the animal that might be trailing me.

A favorite native method of hunting is with birdlime, which is a mucilage made from the gum of a tree. In catching tigers or leopards, the hunter spreads out the birdlime where they will pass and carefully covers it with leaves. Immediately after a cat animal has put his foot in the stuff, he becomes so enraged and helpless that he is easily captured. It is very much like putting butter on a house cat's paws to keep him busy until he becomes accustomed to a new home. The tiger or leopard that steps in birdlime doesn't step gracefully out of it and run away; he tries to bite the stuff from his feet and then he gets it on his face. When he tries to rub it off, he plasters it over his eyes. Finally, when he is thoroughly covered with it, he is so helpless that without much danger he can be put into a cage; and there he spends weeks in working patiently to remove the gum from his fur. Birds and monkeys 
are captured in birdlime smeared on the limbs of trees; they stay in it until some one goes up and pulls them out.

Another way of capturing small monkeys is by means of a sweetened rag in a bottle. The bottle is covered with green rattan and tied to a tree. The monkey puts his hand through the neck and grabs the rag. He cannot pull his hand out while it is doubled up with the rag in it, and he hasn't sense enough to let go. There he sticks, fighting with the bottle, until the hunter comes along and, by pressing the nerves in his elbow, forces him to open his hand and leave the rag for the next monkey.

We snared and trapped many small animals and occasionally built pit-traps for tapirs. The natives sometimes used pits for marsh elephants, but I have never seen elephants captured in them without being injured. They are so heavy that they hurt themselves in falling.

The marsh elephants in Sumatra are not worth the trouble of capturing, since they are weaker, shorter lived and less intelligent than the other breeds. They bring a low price, and consequently only the babies, which can be handled and transported easily, ever reach the market. The usual procedure among the natives is to shoot the mother and take the baby. It is little like the real game of elephant hunting as I found it later in Trengganu and Siam.

Dynamiting for fish is a great sport among the 
Malays. It is done, of course, with the maximum chatter and excitement. The natives line the banks of the stream while the dynamite is dropped; then they rush off, some in boats and some of them swimming, to collect the fish that come to the surface.

Drugging fish is another method of capturing them wholesale without much trouble or work. For this purpose the natives use a mixture of lime and the sap from the roots of a tuba tree. They first warn the villages down-stream so that the people will not drink any of the water; then they pour out the white liquid. It spreads over the stream, making the fish mâbok (drunk), as the Malays say. They rise to the surface and are gathered into boats.

Except for such annoyances as insects and leeches, which fastened on my skin as I walked through the jungle, those days in Sumatra were delightful. We hunted, fished and played games; there was nothing to worry about and little work to do. I was accepted by the natives as one of them. I wore a sârong over my trousers, and I shouldn't have worn the trousers if my skin had not been so sensitive to the insects. And, of course, I had shoes-the great barrier between castes. The Malays of the coast towns sometimes, but not often, wear shoes, and even then it is more a matter of showing-off than of being comfortable. I did everything possible to minimize the differences between us because I wanted to know them as they were, not as they thought I wanted them to be. They 


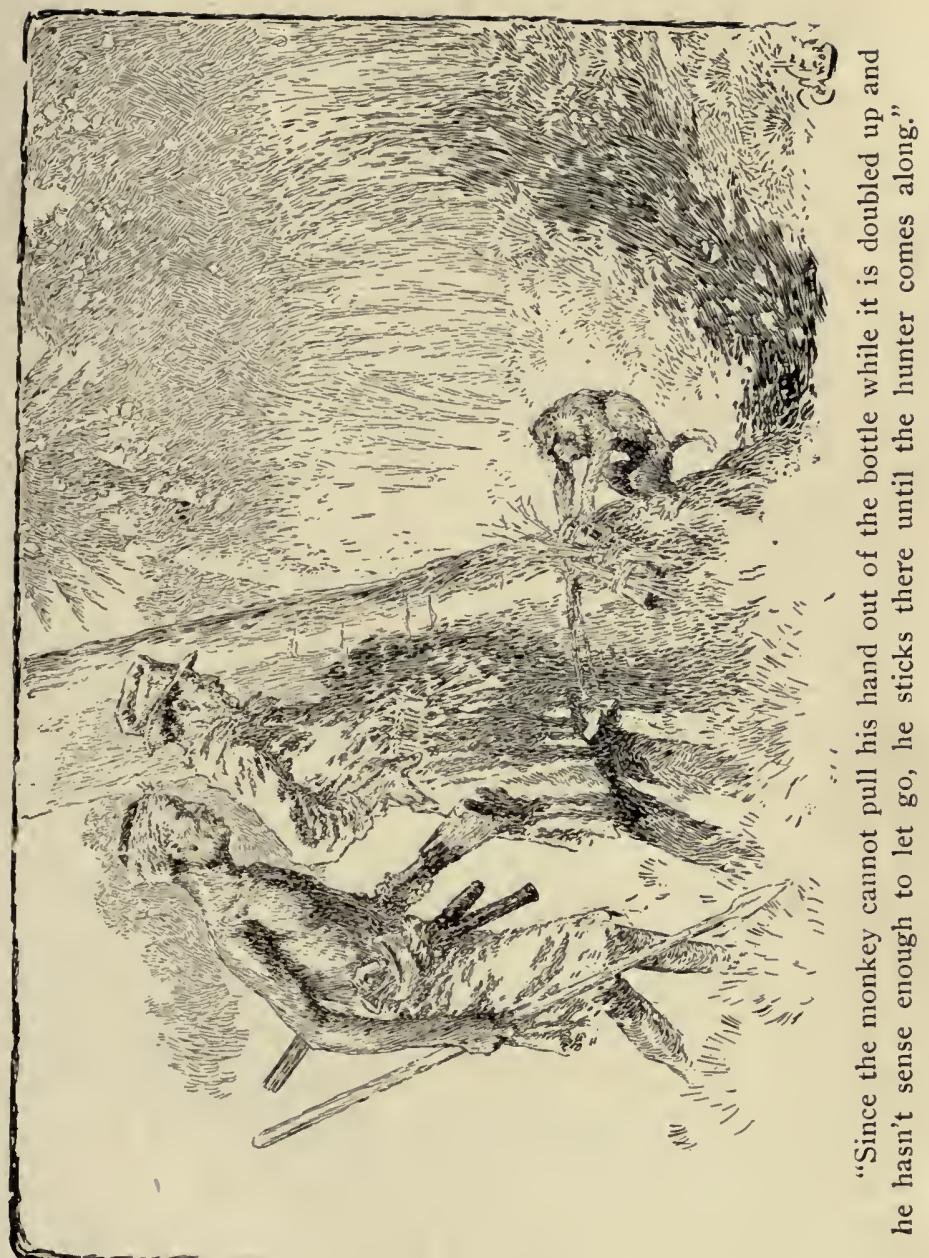



rapidly lost their self-consciousness and treated me. simply as a companion who knew more than they knew - and who had a wonderful gun and a kit of medicine.

In jungle countries white men are always supposed to possess great knowledge of medicines and curing, and I was often called upon to act as doctor. At first the Malays showed some hesitancy at accepting the ôrang pitch ûbat (the white man's medicine), but gradually they became less shy. During my circus days I had acquired a knowledge of first-aid work, and in the jungle I became quite proficient in patching people up. They believed that most ailments could be cured by their own doctors, who heal by magic, but they were glad to have me prescribe for them when magic failed to work.

The Malay doctor is supposed to be favored by a spirit, and a batu bintang (star stone) is given to him while he sleeps. In other words, he is made and not born a doctor. His bâtu bintang is just one of the charms with which he effects cures. He has a bâtu that is a petrified part of a Sembilan fish. Water in which this has been soaked is given to the patient to drink or is rubbed on the part affected. Other charms are the batu lintar (thunderbolt), which is rubbed wherever pain is felt; another bâtu, also a thunderbolt, which is a piece of crystal; a bâtu that is part of the backbone of some animal; one that is another piece of crystal; and, finally, 
the pelican stone. This last is the most highly prized of all. It secures the magic presence and coöperation of a spirit that dwells in the pelican. When the doctor is seeking to enter the spirit world in search of the soul of the sick person, this spirit ensures to him a swift passage there and back. The crystal stone is indispensable in discovering where the wandering soul of the sick person is in hiding and for detecting the spirit who is causing the sickness. And the backbone bâtu cures dysentery, indigestion and consumption.

In practicing medicine for the benefit of the natives, I worked out one theory in regard to leprosy, which is a fairly common ailment in the Archipelago. I asked myself why, since a snake sheds its skin, a man who is afflicted with disease should not be able to do the same thing.

In Singapore there was a rich Chinese leper, known as Ong Si Chou, who asked me repeatedly why I did not bring him some new remedy for his disease. Since he had a large household of servants who took care of him, and his own carriages and rickshaws when he traveled, he was allowed to live untroubled by the authorities; but he was very unhappy, because he had tried all the remedies of the native doctors and was steadily growing worse. At last I told him that I had something that might help. He asked me what it was but I would not tell him. When he insisted, I answered, "Snakes." "Uh-la!" he exclaimed, waving his arms in the 
air. Then I explained my theory. The ability of a snake to shed his skin might be transferred to a human being if he ate snakes; and if so, the person would be able to shed his leprosy. Ong Si Chou did not care for the idea at all, but I told him it was worth trying and I argued that a snake is much cleaner than an eel. At last he consented, and I furnished him with a number of small pythons, with the instructions that they were to be killed and cleaned immediately before they were eaten. He was to eat them raw with his rice.

I left Singapore soon after that, and, when I returned, I found that Ong Si Chou had died. People thought it was a great joke on me because my patient had not survived the treatment, but I am far from. being convinced that the cure will not work-or, at least, help to throw off leprosy. Ong $\mathrm{Si}$ Chou was in the last stages of the disease, and his case was not a fair test.

After living eighteen months with the Malays in Sumatra, I decided that I was well enough equipped to leave and begin the work of collecting wherever I could find the animals I wanted. I went to Singapore and found that Ariff had been maligning me to his heart's content. I called upon him to see what he had to say for himself and he prophesied dismal failure for all my plans. However, I engaged passage on a coast steamer going northward, and stopped off at Kelantan, Patani and Singgora, in Lower Siam. At those places I gathered all the 
information I could about animals and made myself known to dealers. I wanted to make trips to the interior, but to do so I needed a special permit from Bangkok. Instead, I made agreements with all the dealers that they were to send their animals to me, and arranged with the captains and chinchus of the coast-boats for the transportation of the crates. By offering to pay the freight and give them a fair share of the profit, I cut off a large part of Ariff's business.

On my return to Singapore, I found a letter from the director of the Melbourne Zoölogical Society, suggesting that I come to Australia with a consignment of animals. A few weeks later I arrived at Melbourne with a black leopard, twentyfive small monkeys, two small orang-outangs, a pair of civet cats and numerous other animals. Mr. La Souef, the director, and his son, who had just been appointed director of the zoölogical gardens at Perth, met me at the dock. His son bought the entire consignment. The result of this visit was my appointment as agent of the Australian zoölogical gardens. In return for giving them first call on any animals that came into my hands, I was given a retaining fee. The most important part of the agreement was that the animals were to be shipped f. o. b. Singapore and that I was thus released from all the risks of transportation.

It happened too often that animals died aboard ship, after weeks had been spent in capturing them 
and bringing them to port, and this loss was invariably borne by the dealer. Since the agreement with the Australian zoölogical gardens was exactly what I wanted, I returned to Singapore elated. Ariff was crestfallen when he heard the news, and he became more crestfallen when I called on him and told him about the commission I had received from various societies in Australia. I did not want to have him as an enemy, and I foresaw that there would be war between us unless we came to some sort of terms. Consequently, I told him that I wanted to work with him, and that we could do a great deal of business together if he would treat me fairly. He considered the matter for a time, and then, when he saw that I was getting much higher prices for animals than he, he decided that I was right.

One of my Australian commissions was to secure for the New Gardens, at Perth, a pair of tigersmale and female and unrelated. I sent the word out among animal dealers, and, shortly after, I received a cable from a Calcutta dealer named Rutledge, asking me to come at once. I took the next boat to Calcutta and found that there were two tigers up-country near Hazaribagh, a mica mining district about three hundred miles northwest of Calcutta, off the line of the railroad.

I was warned that it was a dangerous country to go through and that the people were thieves. It was suggested to me that I hire a native of the 
locality to protect me. He would do all the stealing he could, they told me, but he would prevent the others from stealing.

The trip was made with a retinue of servants, cooks, bearers and runners, each with his own little task. It was my first experience with the caste system, and I was amazed at the number of people I had to take with me. We traveled by the main road for two hundred miles; then by a branch road to a place called Pachamba. The remainder of the trip was made by ox-teams and bearers, along the line of the government rest-houses erected for the use of officials visiting the country.

We stopped at a rest-house about three miles from the village, and I sent the boy on ahead to buy food for us and to get information about the tigers. Then we engaged one of the local natives to act as guide and guard. I was exhausted by the trip and soon after supper I went to sleep.

A few hours after dark, I was awakened by the most unearthly yell I have ever heard. I jumped up and called the boy I had brought from Calcutta. He was trembling with fright and he said that he didn't know what the noise meant. Remembering all the tales I had heard about the people of this district, I ordered the boy to bar the doors and windows and to lay out my guns. I was well armed with automatics and revolvers and I prepared for a battle. Presently there came another yell, answered on all sides of us. With my guns loaded and ready, I sat 
there waiting. Every few minutes the yell was repeated, and it seemed to be getting closer and closer. At last, however, in spite of it, I fell asleep, exhausted.

I was awakened in the morning by the cook bringing my breakfast and the jingling of the ankle bells of a mail-runner, who was passing the house on his fifteen-mile run. After I had finished eating, the cook returned with the native who had been hired to guard us. The native salaamed and spoke to the boy, who acted as interpreter.

"What is he saying?" I asked the boy.

"He says that he is the head watchman and he wants to know if you slept well with him watching over you." The yells that had kept me up most of the night were the "All's well" of the watchmen. Much to the amazement of the cook and the guard who had come to inquire after my night's rest, I burst out laughing. I laughed so hard that I sat down on the floor and put my head against my knees -I howled.

The guard was given a few rupees and told to keep his watchmen farther away from the house the next night. To this day, when I think of myself sitting up all night, dead tired and fighting off mosquitoes, while my guards became imaginary thieves about to attack me, I laugh.

The headman of the village arrived with several natives and I went with them to inspect the tigerstwo beautifully marked animals. I closed the bar- 
gain immediately and made arrangements to recage the tigers and haul them by ox-teams to Calcutta.

At Perth the directors of the New Gardens were so pleased with the tigers that they sent me a good bonus for my trouble in securing them. And my story about the thieves of Hazaribagh was the joke of the year.

There came a dearth of good animals at Singapore, and so I determined to go into the state of Trengganu to see what luck I should have at collecting. Trengganu was at that time an independent state and had never been thoroughly explored. The Sultan who ruled over it was unwilling to have white men in the country because he feared that his state might become a protectorate of one of the larger powers. He was wise enough to realize that if a white man entered and committed some such indiscretion as interfering with one of the native women, the white man would be found with a kris stuck into him. And the result would probably be that the white man's government would send soldiers to depose the Sultan and take over the government. He wanted nothing more than to be left alone with his country, and so he made it a law that foreigners were not allowed.

At Singapore one heard many tales of the wealth of animals in Trengganu, but it was generally conceded that it was impossible for a white man to 
enter the country. For my part, though I had no idea how to win the Sultan to my way of thinking, I decided that it would be at least as easy as getting a permit to go into Lower Siam. That would have required interviewing $\mathrm{H}$. $\mathrm{H}$. Prince Damerong, brother of the King of Siam and Minister of the Interior, which was no easy matter for so obscure a person as I.

Meanwhile the rumor reached us that an immense herd of elephants was crossing from the State of Pahang into Trengganu, and I made up my mind to act instantly. A roaming herd of elephants is so serious a menace to rice-crops that I thought the Sultan might not object to having the assistance of a foreigner in capturing them. In any event, the chance was worth taking.

With the German captain of a small coaststeamer that called at Trengganu every three weeks, I made arrangements to drop me there. Heprotested that it was a senseless undertaking; that I wouldn't be allowed to land; that, if I was allowed to land, the Sultan would refuse to see me; that, if the Sultan granted me an interview, he would surely refuse to let me go inland; and that, if he allowed me to go inland, I would be killed by the natives. All the way up the coast, I listened to his arguments, and, when he asked me if I had changed my mind, I answered, "You just put me down on the beach, blow your whistle and go along." 
Weeks later, when he returned and asked about me, the natives replied, "Sir, the master is in the jungle catching elephants."

I was on the biggest and most exciting elephant hunt of my life. 


\section{ELEPHANTS}

I WAITED on the beach at Trengganu for a few minutes, until the German steamer was well out of the way; then I sent my Chinese boy into the village to engage living quarters. He returned presently with the information that a Chinese trader had offered to put me up. Ali and I followed him up the street of the village, with a group of inquisitive natives at our heels.

Soon after I had finished my first meal at the trader's house, a tunku (petty prince) appeared with his followers. The meeting was solemn and formal, and he went through the ritual of inquiring after my health, though I could see that inquisitiveness was gnawing at him. At last he asked bluntly what my object was in coming to Trengganu.

"I have come to see the Sultan on important business."

He told me that it would be impossible for me to see the Sultan and offered to deliver my message. I waved him aside and told him that I must see the Sultan personally.

"Impossible," he replied, and departed in the direction of the palace. The palace was a halffinished, two-story brick dwelling. The Sultan had 
never been able to gather enough money to have the building completed; but, at that, it was the most imposing house in Trengganu.

An hour later, I started out with Ali and the Chinese boy for the palace, to pay my respects to the Sultan and make another request for an interview. At the gate I was met by a tunku, who told me that the Sultan would not receive me. I returned to the trader's house and slept through the hot afternoon. When evening came, I went again to the palace and met with the same reception.

Twice a day for the entire week I called at the palace. I appeared to be making no headway, but I had been associated with the Malays long enough to know that the Sultan could not bear the strain much longer. Also, I knew that if I gave a tunku the least inkling of my purpose, all my hopes of hunting in Trengganu would be wrecked.

The Sultan gave in at last; he sent word to the gate that he would receive me, and I was ushered into the "reception room" of the palace. The Sultan, a middle-aged, scholarly-looking man, was waiting for me, with his retinue squatted around him. I gave him my card.

"What is it?" he asked.

"My name," I replied, bowing.

"What country are you from?"

"America."

He looked surprised and asked if I was English, French or Dutch; he thought that all white men 
must be of one of those races and that America was probably a colony.

Fortunately, I had some maps with me. I spread them on the floor and held a class in geography, with the Sultan and his retinue bending over me, listening intently. The Sultan was as enthusiastic on the subject of America as if he had discovered the country. I told him about our president and how he is elected, about the states and governors and the legislatures and Congress.

At last he lost interest in America and asked why I had come to Trengganu. I told him I had come to trap animals and I wanted his permission. He shook his head and replied that there were no animals in Trengganu.

"If you will send your messengers out," I answered, "you will find that an immense herd of elephants is crossing from Pahang into your country."

"How do you know?"

"I heard." It was a Malay answer, and I could see that he was interested. A roaming herd of elephants is dangerous; it spoils rice crops, terrorizes the natives-and most important of all-reduces the Sultan's income.

He ordered coffee and Malay cakes and plunged into thought. The coffee was muddy and bitter, but I drank it joyfully because I knew the Sultan, being worried, would probably see the wisdom of allowing me to enter his country and capture the 
elephants. Also I suggested that he would receive a bonus on each animal I captured. He nodded and asked me to come to the palace the next day.

Each day for three weeks I called on him and spent hours in telling him of my travels. And he told me something of the worries of being a Sultan. He was afraid that one of the big powers would establish a protectorate over Trengganu, depose him and reduce his people to slavery. He knew very little of foreigners, but he had come to the conclusion that the best thing to do was to keep them out. What did I think was the best plan? We held long conferences, in which I enlightened him on the ways of white men. The subject of elephant hunting scarcely came into the conversations, but I knew that he had sent messengers out to see if there was any truth in my story about the herd crossing from Pahang. I was slowly winning his confidence; everything depended upon the truth of that rumor I had picked up in Singapore.

Exactly three weeks after our first meeting, he greeted me with the words: "Thân châkap bêtul (Sir, you spoke the truth)."

"I always speak the truth," I answered, as if I were annoyed. The messengers had returned with the news that the herd had been seen near the Pahang River.

He asked what I proposed to do, and I drew a diagram of the trap I wanted to build. He asked if it would not be a better plan to shoot the big 
elephants and capture the young. I put stress on the royalty payments he would receive, and thus I won him to my way of thinking.

He assigned his nephew Omar-a tunku - to the duty of assisting me, and gave him full power to force as much labor as we might need. A few days later, Omar and I, accompanied by the Sultan, sailed down the coast to the Pahang. It was a wide, deep river, infested with crocodiles; settlements dotted the banks. At each of these we stopped and called on the headmen to conscript labor.

Since the men had to supply their own food and travel in their own boats, the cost of the expedition was reduced to nothing. We arranged that the men might be replaced by others from their villages, because they were loath to remain long away from their families.

Five days after leaving the capital, we arrived at the place where the herd had been located. We disembarked. There followed two weeks of hunting before we found the spoor that told us we had reached the elephants.

It was dense jungle; undergrowth, creepers and vines bound the trees together. The lack of sunlight and the dense atmosphere made progress slow. Sometimes the task of driving elephants on foot through such country seemed hopeless, but I kept the men at work, hacking out trails with parangs-their big knives. The insects were 
frightful, and we were all covered with bites. I developed fever and went about so "groggy" that I was not at all sure of myself; but huge doses of quinine and the excitement of tracking so large a herd kept me going.

The scouts reported that the herd numbered about one hundred. I assigned fifty men to surround the elephants and keep them moving in a circle within a definite area while we built the stockade.

The work of making the trap was prodigious. Trees, twenty to twenty-five feet in length and a foot and a half in diameter, were cut down and dragged through the jungle for half a mile or more to the spot I had selected. These were planted five feet in the ground and braced by three smaller trees, so that they could stand the enormous pressure of elephants trying to lunge through them. The trap was round-about seventy-five feet in diameter-with two wings, each one hundred feet long, converging to the entrance. After planting and bracing all the posts, we bound them together with heavy ropes made of twisted rattan, and then covered them with vines and leaves. For all this work the natives had no tools except their parangs. It was amazing to see the rapidity with which they cut down the big trees and slashed trails through the jungle. Omar and I were with them constantly, keeping up their enthusiasm and excitement. 
In building the trap we took great care not to disturb the jungle through which the elephants were to be driven. Like all jungle animals, elephants can see at night, and there is always the danger of a stampede unless precautions are taken against arousing suspicion. The jungle leading up to the wings was untouched; and the wings and the trap could scarcely be distinguished from the dense growth that surrounded them. In the runway and in the trap the jungle was still standing without injury.

When the stockade was completed, an old Siamese priest offered to perform the ceremony that would bring the blessing of the deity of the jungle upon the drive. A white cock was found and fastened in the center of the trap. The priest selected a hundred men and stationed them near the entrance with fruits and branches of trees; then, with two natives, he withdrew into the jungle. Presently we heard them shouting. They came through the undergrowth, chanting and striking the trees with their spears and parangs. The priest rushed through the runway into the trap and seized the cock. With his knife he severed its head. Then, while the natives joined in a chorus of shouts, he ran about the trap, sprinkling the blood. Instead of coming out through the gate, he crawled between the posts. The ceremony ended, and the natives were ready to begin the hunt.

Word came from the men who were watching 
that the herd was four miles away. I gathered the natives around me, explained all the details of the drive and assigned men to the various tasks. Then we started in a body to get behind the herd. Every five hundred yards, I stationed a man in a tree to steer the drive.

Driving elephants at night is a slow, trying, dangerous job. It means fighting every foot of the way through dense jungle and keeping up a continual hubbub of tom-toms and shouts. The elephants wish to avoid the noise and they move slowly away from it, crashing through the trees and vines. The men who are directly behind have the easiest time, for they can follow the trails broken by the elephants; those on the side must cut trails with their parangs. No lights can be used, and care must be taken to avoid the little elephants, which roam about, investigating the noise. If they see a man and give the danger-signal, the entire herd stampedes.

When we arrived behind the herd, I spread the men out in a $U$ formation, warning them to make no noise until the signal was given. With Ali standing near me with my express rifle, I waited until darkness came; then I gave the signal and started forward. Ali, Omar, the priest, my Chinese boy and a few others followed along behind me, shouting. The noise was taken up on each side of us, and presently we heard the elephants moving forward, throwing their great hulks against the jungle growths. The night was black, and we stumbled 
on, guided only by the calls of the men in the trees. Insects swarmed about us, biting until we were frantic. Sometimes the noise on either the left or the right suddenly increased, and we knew that the herd had veered in that direction and that the men were frightening them off.

Dawn came, and we found that we had driven them a mile and a half. It had been exhausting work. I posted guards to watch the herd, and we slept until late in the afternoon. Our bodies were covered with welts from insect bites and the sting of nettles and were torn and scratched by the sharp vines; and I was throbbing with the fever. When darkness came again, it seemed to me that the enterprise was all a wild nightmare.

Early the next day the stampede hit us without warning. A small elephant, straying from the herd, saw some of the men on the right; he ran back, trumpeting the danger. Then the bellowing herd came down upon us.

Ali shoved my rifle into my hands and I jumped behind a tree. The Siamese priest stumbled and fell. Before I could shoot, a big bull elephant stepped on him and tore him in two, throwing the upper portion of his body over my head. I was spattered with blood. Elephants, bellowing furiously, rushed past us; men screamed and scrambled for places of safety. The immense animals loomed up in the darkness for a second and then disappeared. In their excitement some collided with trees. 
There was no need to shoot; it would have been like holding up a fan to fend off a cyclone. I hugged my tree, keeping my gun in position. I was discouraged; our efforts had been wasted and the herd was scattered. That would be a fine story to take back to the Sultan.

When the elephants had passed, I called to the men. We lighted torches and searched for the injured. Three had been killed and twelve hurt, and I was thankful there weren't more casualties. We buried the dead. Ali brought up my medical kit and helped me dress the wounds.

After a few hours' sleep, I found that I wasn't quite so discouraged, and so I called the men together and lectured them on the necessity of being careful. They showed no signs of mutiny, and so we started off again in search of the herd. It was not difficult to find them, for they cut a swath in the jungle to the point where they stopped, five miles from the scene of the stampede.

Again I posted guides in the trees and spread out the drivers. Every man was alert, and, when night ended, we were considerably nearer the trap. In the minds of the elephants there seemed to be no connection between the noise that was driving them and the men they had seen the night before, and they went ahead peaceably.

Leaving scouts to watch the herd, I gathered the men together and praised them. Success rekindled the enthusiasm that had been damped by the 
stampede, and, when we threw ourselves down to snatch a few hours' sleep, we were convinced that the drive would proceed without trouble. The scouts reported that the herd was slightly depleted, but, even so, it was the largest herd that any of us had ever seen, much less driven.

At nightfall, each day, the men were again in position, waiting for my signal; and, three nights later, we approached the stockade. The men went wild with delight. And above the uproar, I could hear the calls of the guides in the trees, telling us our distance from the trap.

The big beasts jammed in the runway between the wings, heaving and struggling, and forcing those ahead of them into the trap. The walls of the wings groaned as they threw their bodies against the posts. The elephants bellowed, and the natives kept up a continual pandemonium. I mounted the platform and looked down; I could see nothing but a tossing flood of black that poured slowly from the runway into the trap.

When the last elephant was inside, the ropes that held the gate were cut. The gate crashed down; bars were run through the sockets; the elephants were trapped.

On my platform I shouted as loudly as any of the Malays. Torches were lighted and the men began dancing. I slipped to the ground and warned them against climbing up on the walls of the stockade, for I was fearful that the sight of men might en- 
rage the elephants. If the beasts suddenly took it into their heads to charge the wall in a body, some of the posts might give way. I could hear them milling around inside the trap, bellowing and tearing up the jungle in an effort to find a way out. Through the remainder of the night the natives danced, ate and drank. Then, when dawn was beginning to light up the sky, I climbed to the platform again and looked down into the trap. There were sixty elephants!

The men, armed with long, spiked poles, mounted to the running platform on the top of the posts, and the celebration was renewed. I stood there, breathless, wondering how many of them, in their excitement, would fall off the platform into the trap. But none did fall, and they fended off the charges of the elephants by sticking them in the heads and bodies with their spikes.

Omar immediately sent a messenger to the Sultan with the good news, and the word passed from village to village. Natives poured in to inspect the catch, and the messenger returned with the news that the Sultan was on his way. It was a historic occasion in Trengganu. The Sultan had never been in the interior of his own country before, and never had there been such an elephant hunt in the state. Omar busied himself with the details of the royal reception while I cared for the catch.

We cut holes in the rattan webbing between the posts and enticed the small elephants to come out. 


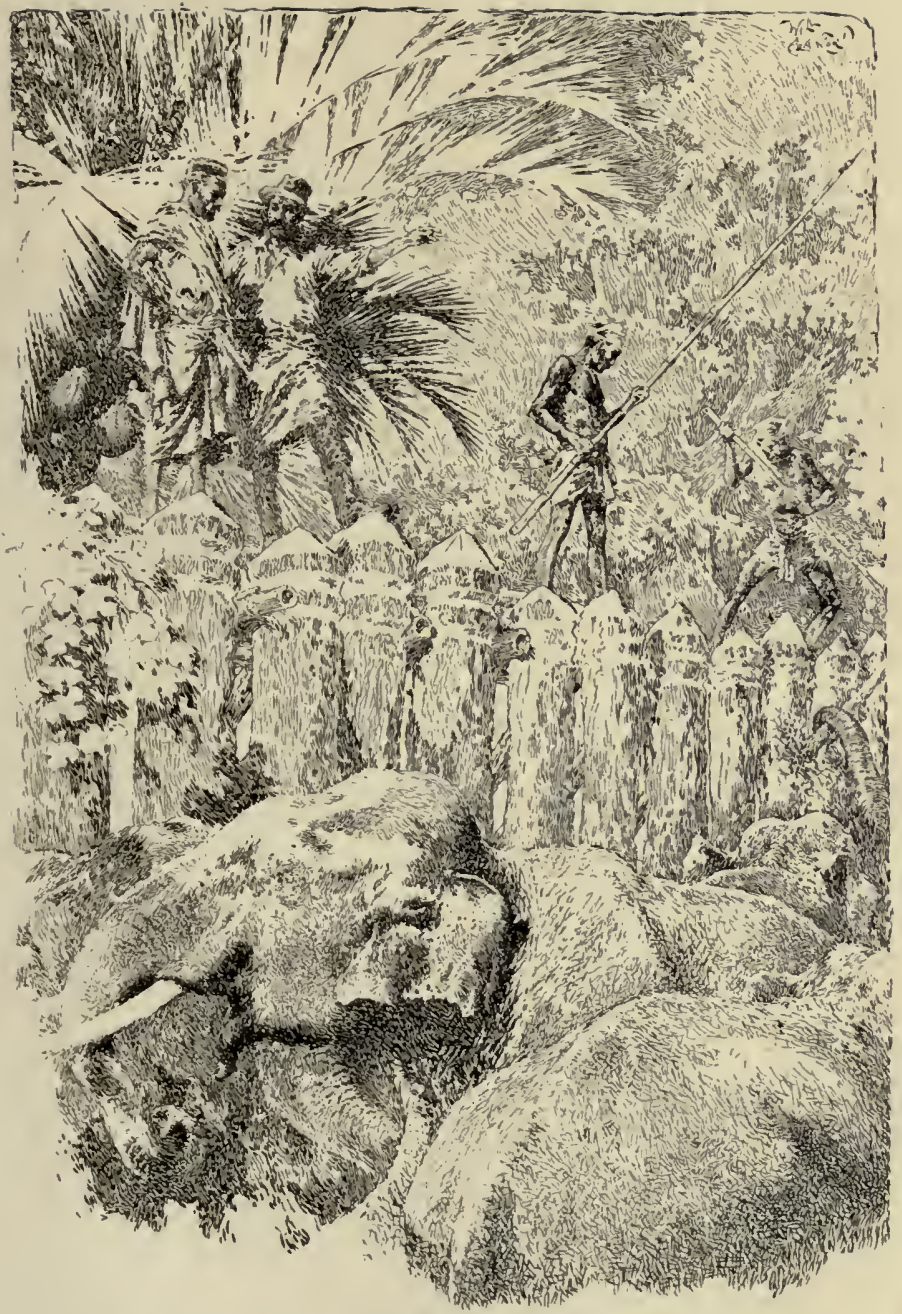

"I climbed to the platform and looked down into the trap.

There were sixty elephants." 

There were several babies in the lot, and they soon became playful and affectionate. Baby elephants are just three feet high at birth and weigh about two hundred pounds. They grow an inch each month. We made pets of them and amused ourselves with weaning them. We did this by taking a pail of warm milk and dipping the babies' trunks into it, then doubling the trunks up and putting them into their owners' mouths, and finally squirting milk in with a squirt gun. The babies soon learned to imitate this procedure. They were mischievous little animals, full of fun and inquisitiveness. Hour after hour, I played with them and laughed until I ached.

The Sultan arrived with his retinue, and we gave him a ceremonial greeting. Deputations from all the villages were present, and Omar requisitioned food for a great feast. The Sultan had little to say about the elephants until I took him up on the platform where he could count them for himself. For a minute he looked at them, wide-eyed; then he repeated, "Sir, you spoke the truth."

"I always speak the truth," I replied, and I could see by his expression that he believed me. He was convinced that I was honest. I knew that I had his protection for any expeditions I might undertake in Trengganu. His friendship had been difficult to win, but it was worth the trouble-quite aside from the value of the elephants. Trengganu was virgin country, filled with animals that my custo- 
mers wanted to buy, and I had the exclusive privilege-so far as foreigners were concerned-of hunting there. And, since the Sultan received a bonus on the animals captured, he provided me with labor.

The Sultan remained several days and we spent much of our time in talking over the problems of government. These conversations ended by my becoming a sort of foreign adviser in all dealings with European countries. Later, before Trengganu was made a British protectorate, he awarded me some valuable tin concessions. The new arrangement under the British government was made satisfactorily; he received a suitable pension and he passed happily into a purely honorary position in his state, relieved of all the complexities of political administration. When I last saw him, he was living in indolent comfort, surrounded by his wives-and his two-story brick palace was at last completed.

It took more than a week after the departure of the Sultan of Trengganu for the natives to get their fill of celebration. While they feasted and danced, I made my plans for the stocks in which the sixty elephants were to be broken.

The breaking of elephants, especially so large a herd, is a long, tedious job. I was thankful that I had Prince Omar with me to keep the natives working. The hunter, who kills and skins his animals, has a simple life compared with the collector, who must not only take the animals alive and uninjured, 
but convey them through miles of jungle country to a port. Months of hard labor were before us, and the success of the expedition was by no means assured, even though we had our elephants safe in the stockade. It was to be a great test in managing the natives.

There is only one thing that a Malay values, and that is his kris-his knife. To lose this cherished possession means to lose honor. There is a saying to the effect that money will buy everything but a lucky kris. Their disregard of money makes all dealings with Malays extremely difficult, and their dislike for work has completely blocked more than one project. To my mind, the Malays are the laziest people in the world.

When work is an exciting or amusing game, such as the hunt, they will go on for days without signs of fatigue. They seem to keep alive by some fanatic energy. But when work is just plain labor, they will say "Wait," or "I must think." Or a Malay may say candidly: "Sir, I have just had plenty to eat. I am content." Many times I have had a Malay tell me, when I asked him to do some work, that he had enough rice and fish for the day and that he might die during the night. It is an unanswerable argument. Tomorrow's food can be found when tomorrow comes.

The Malay's food is simple and his clothes are few. With no more effort than dropping a few seeds and covering them with earth, he can grow 
most of the food he needs, aside from his rice and fish. One catch of fish will supply his family for weeks and give him a surplus to sell to the Chinesc traders. With the money he can buy some cloth and a little powder. Six or seven good-sized chickens cost one Mexican dollar; eggs cost one Mexican cent; yams, one or two cents each; pineapples, two or three cents. Why worry about the tomorrow that may never come? Why should a Malay gentleman, who believes in Allah and whose stomach is full, do the labor that can be done by heathen, pigeating Chinese?

"Will you row me across the river?" I asked a Malay one day.

"Tûan, I have eaten and I have had plenty," he responded. "You may take my boat and row yourself across the river. Tomorrow, if Allah grants me life and if I need the boat, I will swim over for it."

That Malay trait of living for the moment has led many a European to murder, and more than once it made me feel like running amok. It is maddening. Getting work out of Malays is a fine art, a science to be learned only after years of patient arguing and cajoling. And yet, with all their laziness, they are lovable people. In most cases they are brave and willing to do anything for a person they like.

Under the circumstances, sick with fever and worn out by the drive through the jungle, I was en- 
titled to some doubt as to what the next few months would bring. The Sultan had left strict orders that I was to be provided with all the labor I needed, and Omar was there to assist me. However, I waited with anxiety to see what the attitude of the natives would be after they had finished celebrating, and I was encouraged to find that I had earned the name Tûan Gâjah-Sir Elephant. They were deeply impressed by the power of the white man who had engineered a great drive of sixty elephants and who owned the exceedingly marvelous gun that his man, Ali, displayed with such proud ostentation.

Inasmuch as they were receiving no money for their work, they had some right to object, but I humored them with promises of celebrations and games. The white man's camp became a popular place in Trengganu. Wonderful tales of what was done there spread through the country, and the men who had been to the camp could command an audience in their home compounds when they returned. The elephant drive was a historic event in the country, and henceforth we had little trouble with labor.

The work of breaking wild elephants must be carried on with painstaking exactness, for one elephant can create havoc in a few seconds if the men lose control. The first task is the building of the stocks where the elephants are to be held while they become acustomed to men; then comes the work of driving into the ground, about four feet apart, two 
rows of heavy stakes, leading from the trap to the stocks. Also, next the trap, a small enclosure, four or five feet wide by fifteen long, is built at the end of the passageway formed by the stakes. The piles of the trap are removed from the entrance to this enclosure and bars are substituted. Since the elephants were given practically no food during the time they were kept in the trap, they were half starved when the breaking commenced. In their weakened condition they were much less dangerous to handle, and, too, they could then be fed in such a way as to impress upon them the fact that good behavior brings good treatment.

The young elephants required no breaking, and so they were lured from the trap with food. They roamed about the camp, playing and watching operations.

As soon as the tuskers were taken from the trap, they were killed for their ivory. The tusks were worth almost as much as I could get for the live animals, and tusks are far easier to handle than animals that have to be broken and fed. Also, as the animal dealers say, the elephant might "eat and die." I did the killing with my express rifle. The explosive bullets produced instant death. Another way of killing an elephant is to strangle him by running two ropes around his neck and having elephants pull him in opposite directions.

As soon as all the equipment for breaking was ready, I instructed the natives in their work. With 
a select crew of men, I rehearsed all the details of what we were going to do and how we were going to do it. Finally, I ordered food placed in the enclosure and the bars drawn. The nearest elephant saw the food, sniffed, flapped his ears and walked in. Breaking commenced.

As soon as the elephant enters the small enclosure, the bars behind him are slipped. He eats the food so eagerly that he does not realize quite what is happening and the men put the knee- and foothobbles on him. These allow him about one quarter of his normal step. Rattan ropes are fastened to his feet and drawn out through the bars; his trunk is secured so that he can do no damage with it.

There is a great deal of misunderstanding about what an elephant can do with his trunk. It is a sensitive organ and he never uses it for heavy labor, but he can strike a terrific blow with it. I have seen many a man's ribs and arms broken when he neglected to take the proper precautions. In approaching a dangerous elephant, a man should come up sideways, with the nearer arm folded to protect the ribs. Then, if the elephant strikes, he should try to catch the blow on the upper part of the arm, where there is the most flesh to protect the bone. Such a blow never knocks a man flat; it sends him spinning like a top until he tumbles over.

The elephant uses both his trunk and his lungs in calling, and he has a large variety of sounds and combinations of sound with which to express him- 
self. When rushing an enemy, he trumpets shrilly; when enraged by wounds, he grumbles hoarsely from his throat; he expresses fear by a shrill, brassy trumpet and a roar; and pleasure by a continued low squeaking through the trunk. When apprehensive of danger or when attempting to intimidate an enemy, he raps the end of his trunk smartly on the ground and trumpets. The peculiar noise sounds like that produced by the rolling up of a sheet of tin.

In a moment of danger, the elephant coils his trunk to protect it from injury. When he is engaged in heavy work, such as piling lumber, he may use his trunk to balance the load he is carrying on his tusks, but never to bear part of the burden. If an unharnessed elephant must pull a rope, he holds it in his mouth, taking good care to keep his trunk out of the way. It has happened many times that an elephant-keeper-not a trainer, for a trainer knows better-has used a hook a little too freely on an elephant's trunk. If he doesn't get killed, he picks himself up several yards from where he was standing. A trainer is invariably pleased at such an occurrence, because it shows that the keeper was abusing the elephant and has merely received his deserts. The elephant is a good, faithful animal, and he does not attack his keeper without excuse, except when he is in what is called the "must" period, which I shall describe later.

When the elephant is secured by hobbles, footropes and trunk-ropes, the bars leading from the 
enclosure are removed. The foot-ropes have been fastened to the stakes and are loosened as the elephant walks out. The men holding the ropes attached to the fore feet wind them around the two stakes ahead, and those holding the ropes attached to the hind feet wind them about the first stakes. In this way the animal is drawn forward, step by step, toward the stocks, while natives prod him from behind with poles. If he tries to bolt, he simply falls over. It is a difficult, trying job, because the elephant is still vicious.

The stocks are built in covered stalls, so that each elephant is separate from the others. Two large uprights are driven into the ground in the shape of a V; the elephant's head is drawn between them, and they are pulled together at the top so that he is held securely behind the ears. At the corners are uprights, with poles to fence him in, running between them. These poles, located a trifle below his belly, support two cross-bars, one just behind his fore legs, and the other in front of his back legs. In this position it is impossible for the elephant to lie down or to move; he can wiggle his legs and wave his trunk, but that is all.

The elephant remains in the stocks for about two weeks. During that time he is fed and petted by a keeper appointed for that particular job. The keeper irawls over his back and rubs him behind the ears and gives him water, fruit and bamboo shoots. The elephant learns not to be afraid when a man is 
near him, and he gradually becomes more docile. During these two weeks he is fed very lightly because he must be kept in a weakened condition.

After two or three weeks, according to the disposition of the elephant, ropes are again attached to his feet, and he is led out of the stocks. This time he wears only the knee-hobbles, which allow him more play. Eight or ten men hold each of the ropes; his keeper sits on his head with a prod; another crew hold the rope attached to his trunk; and six or eight men follow with rattan whips. The men with the whips beat him continually. At first, in the excitement, he does not mind the whipping; then he finds the pain unbearable. The men on the trunkropes lead him about from right to left, while the men on the foot-ropes stand ready to trip him if he tries to bolt. At last he gives a bellow of pain and the whipping stops.

This one bellow marks a surprising change in the animal. His spirit is broken and he acknowledges that man is his master. The fact that he is instantly fed and petted helps him to make up his mind, of course, and to forget about the old, wild ways of the jungle. Thereafter, a keeper who does not deliberately make him angry can handle him easily. His schooling is brief and he learns readily to turn, kneel, back and pull. In return he is given plenty of food and is tied to a tree instead of being put in the stocks.

It occasionally happened that an elephant refused 
to bellow. In that case, I had the men lead him out to be shot, for I knew I should be wasting time in trying to break him.

The opinion is generally held by those who have had the best opportunities of observing the elephant, that the popular estimate of its intelligence is a greatly exaggerated one; that instead of being the exceptionally wise animal it is believed to be, its sagacity is of a very mediocre description. Of the truth of this opinion no one who has lived amongst elephants can entertain a doubt.

The elephant's size and staid appearance, its gentleness, and the ease with which it performs various services with its trunk, have probably given rise to the exalted idea of its intellect. Amongst those not intimately acquainted with it, and it being but little known outside of its native countries, what is known of it justly make it a general favorite and leads to tales of intelligence being not only accepted without investigation, but welcomed with pleasure.

One of the strongest features in the domesticated elephant's character, is its obedience. It is also readily taught, but its reasoning faculties are far below those of a dog, and possibly other animals, and in matters beyond the range of its daily experience, it evinces no special discernment; while quick at comprehtilding anything taught to it, it is decidedly wanting in originality.

Let us consider whether the elephant displays more intelligence in its wild state than other ani- 
mals. Though possessed of a proboscis, which is capable of guarding it against such dangers, it readily falls into a pit dug for catching it, only covered with a few sticks and leaves. Its fellows make no effort to assist the fallen one, as they might easily do by kicking in the earth around the pit, but they flee in terror.

It commonly happens that a young elephant falls into a pit near which the mother will remain until the hunter comes, without doing anything to assist it, not even feeding it by throwing in a few branches. This, no doubt, is more difficult of belief to most people than if they were told that the mother supplied it with grass, brought water in her trunk, or filled up the pit with trees and effected the young one's release.

Whole herds of elephants are driven into ill concealed enclosures which no other wild animal could be got to enter, and single ones are caught by their legs being tied together by men under cover of a couple of tame elephants. Elephants which happen to effect their escape are caught again without trouble. Even experience does not bring wisdom.

These facts are certainly against the conclusion that the elephant is an extraordinarily shrewd animal, much less one possessed of the power of reasoning in the abstract, with which he is commonly credited. I do not think I traduce the elephant, when I say it is in many things a stupid animal, and I can assert with confidence that all the stories I have 
heard of it, except those relating to feats of strength or docility performed under its trainer's or keeper's direction, are beyond its intellectual power and are but pleasant fiction.

It often happens that persons who do not understand elephants give them credit for performing actions which are suggested to them, and in which they are directed by their trainer or by the mahout on their necks. I think that all who have had to deal with elephants, will agree in saying that their good qualities cannot be exaggerated and that their vices are few, and only occur in exceptional animals. The not uncommon idea that elephants are treacherous and retentive of injury, is a groundless one.

Elephants do not push with their foreheads or the region above their eyes, but with the base of the trunk or snout, about one foot below the eyes. Elephants are poor sighted, and are so intent on being off when thoroughly started, that I have been almost brushed against without being discovered.

The rapidly advancing line of huge heads and cocked ears bobbing up and down as the elephants come rushing on, leveling everything before them, is a trying sight, and at first one requires some nerve-and the reflection they are escaping, not charging-to stand still.

If circumstances ever occur to make a run unavoidable, the pursued hunter should always take down hill and choose the steepest place at hand, as the elephants fear to trust themselves on a rapid 
descent at any great pace; uphill, or on the level, man would be immediately overtaken. When elephants are close at hand, standing in indecision, no one should shout to turn them; a charge by one or more of them is sure to be made if they are suddenly started at this time.

Eight months passed at breaking elephants. I was sick with fever and dysentery and I was glad when we could break camp. Riding on the head of an elephant, I led my catch through the jungle to port. Once again I paid my respects to the Sultan, who told me that I might hunt in Trengganu whenever I pleased. A year before, I should have been wildly delighted at the prospect of having Trengganu open to me under his protection, but now, with my health broken, I did not care much if I never saw the country again.

I arranged for the keeping of the animals until they could be brought by boat to Singapore, and then I caught the first coast steamer south, taking four elephants with me. At Singapore I found that the story of the big capture had been the talk of the city for months. In fact, several days after I arrived, I went to call on my former enemy, Mahommed Ariff, and he took off his turban and bowed. We had many dealings after that, and he always treated me with the greatest respect and honesty.

When I was leading one of the smaller elephants through the street on my way to the animal house 
I had rented in Orchard Road, I was approached by an Arab.

"Tûan man jûal? (Sir, do you wish to sell?)" he asked.

"Of course," I answered. I was sick and tired and I did not want to be bothered.

He persisted. "Tûan, how much?"

"All of them or just one?"

"That one," he answered, pointing to the elephant I was leading.

I thought he was asking just out of curiosity, and so I set a price that I thought would silence him\$3,000 Mexican.

"Tûan, truly will you sell it for that?"

"Yes."

He followed me to the animal house, and I wondered what he had on his mind. As a matter of fact, I would have sold the elephant for $\$ 450$, because it was young and small. At the animal house, he again asked me if I would sell for $\$ 3,000$; then he undid several of the shirts he was wearing and pulled forth an old wallet. He gave me $\$ 500$ to bind the bargain and called a friend of his to act as witness. When he left to get the rest of the money, I went to the stall where I had placed the animal and examined it.

It didn't take me long to discover why the Arab was willing to pay $\$ 3,000$. The little elephant had twenty toes instead of the usual eighteen. Twentytoed elephants are held in veneration throughout 
India, and are keenly sought by all the rajas and maharajas for the prosperity they are supposed to bring. They are guarded more carefully and quartered even more sumptuously than the white elephants of Siam, and the price they will bring is determined almost entirely by the amount the rajas can gather together. My little twenty-toed elephant was a faultless specimen. He was about five years old and stood four and a half feet high. His head was perfectly shaped; his back was straight and absolutely even with the top of his head.

I was naturally disgusted to think that I had let such a bargain slip out of my hands, and, when the Arab returned, I blamed him for cheating me when I was sick with the fever. I abused him and his ancestors and gave a great show of indignation. He begged me to take the money and give him the elephant; I refused the money and told him to take the elephant out of my sight.

"I have put a curse on him," I said. "He will be dead within twenty-four hours."

At this he burst into tears, begging me to remove the curse. He said that he was a poor man and that the elephant's death would ruin him. Finally we reached a compromise. He would pay me an extra $\$ 500$, and I would arrange transportation to India for the elephant. Then, if the sale proved profitable, he was to return to Singapore and pay me an additional $\$ 500$. He swore by Allah and the Prophet that he would keep his word. So I re- 
moved the curse and took his money and he departed happily. A month later he returned and paid me the \$500. He had sold the elephant to the Maharaja of Mysore for I0,000 rupees. The Arab later bought four large elephants from me.

During my nineteen years in the Malay Archipelago I captured hundreds of elephants, but none of the herds was so large as my first catch. And, though I always looked carefully at the elephant's feet before I sold him, never again did I lag one with twenty toes.

Of all the animals I have handled in my experience as a collector, I prefer elephants. They are interesting and amusing beasts, and, once broken, they become hard-working and affectionate. They never show any inclination to go back to the jungle, even when used for the purposes of running wild elephants. In Siam all the driving of herds into the traps is done on female elephants, and their presence calms the herd. I have seen the tame elephants press in upon a wild elephant, holding him while he docilely allowed himself to be hobbled.

The hunts in Siam are for tuskers, and the females are for the most part allowed to run free again to breed. The tuskers are used in the teak forests for handling logs. The females bear young about every three years until they reach an age of from seventy to seventy-five years. The period of carrying varies from eighteen months in the case of a female baby to twenty-one months in the case 
of a male. A baby elephant, as I have already written, weighs approximately two hundred pounds at birth and stands thirty-six inches high. It suckles from six to nine months. The breasts of the female are located just back of the fore legs, and the baby runs its trunk up along its mother's side while nursing. Its next food is fruit and the tenderest bamboo shoots. It is very fond of sugar. It grows at the rate of one inch a month up to its third year and attains its full growth, but not maturity, at about twenty-five. The age of an elephant is told largely by the ears; an old animal has ragged ears and sunken cheeks. The height of an elephant is almost exactly twice the distance around its foot.

A herd of elephants is invariably led by the females, perhaps because they are the more alert to catch the least sign of danger. If the herd is put to flight, the males take the lead, breaking through the jungle and making a trail for the females and young. An elephant never goes around things; he either pushes them to one side or goes straight through. He is very sure-footed and, on anything that looks doubtful, he will never step without first putting out a foot and trying it. For that reason, it requires some skill to build a pit-trap that will not attract attention. A pit-trap is practically useless, however, because the elephant is invariably injured in the fall; it allows the capture of the baby, in the case of females, but at the cost of the good, full-grown animal. Wild elephants, grazing in a 
herd, travel rapidly if they are frightened, but usually they saunter along, sleeping during the day and feeding at night. Their food consists chiefly of grasses, bamboo shoots, cocoanuts and the bark of some trees. Lone elephants and outcasts from the herd are dangerous animals and should be killed.

There comes a period, known as "must," when even the most reliable elephant becomes a dangerous animal. Like the Malay he "sees red" and runs âmok. A good elephant keeper can detect the madness several days before it reaches the dangerous stage, and by securing the animal with hobbles, can prevent trouble. In the cheeks of the elephant are two small holes, called "errors," and from these holes oozes a slight secretion. One of the keeper's duties each day is to examine the holes and run a piece of straw into them. If there is an odor of musk about the straw when he pulls it out, it is an indication that the "must" period is coming. Sometimes the keeper fails to make this test, and the elephant runs âmok, killing people and leaving a trail of wreckage behind him.

On one of my visits to Sydney with a consignment of animals for the Zoölogical Gardens, I found the entire crew of elephant keepers busy with the task of trying to control an animal that was in "must." His keeper had failed to make the test, and the elephant had suddenly gone mad. Fortunately he was in his stall at the time. When I ar- 
rived, he had wrecked the stall, and the keepers were afraid that he might get loose. Another stall had been arranged, but they could figure out no way of changing him to it. The men were thoroughly frightened and absolutely refused to risk hobbling him. The director of the Gardens offered me $£$ IOO if I would do it, and, since I had Ali and several of my own men with me, I agreed to try.

With elephant hooks strapped to our wrists, we entered the stall. The elephant stood looking at us, apparently wondering which one he should knock down first. I told Ali to get behind him while I approached from the front.

I went up to him sideways, speaking to him and offering him food. He waited quietly until I was near enough; then, before I could duck, he hit me with his trunk. I felt myself spinning so rapidly that the elephant, my men and the stall were all a blur; and I came up against the wall with a thud. Fortunately, there was a gutter running along the wall, and I dropped into it just as the elephant lunged forward at me. His big head hit the wall and the floor but couldn't get at me. He would not risk his trunk, because he realized that I would jab him with the hook.

Ali and the other men were at his tail, jabbing him and pulling. When he turned for them, I jumped up and began running my hook into his side. It became a game of jabbing and dodging and worrying him to first one side and then the other. I 

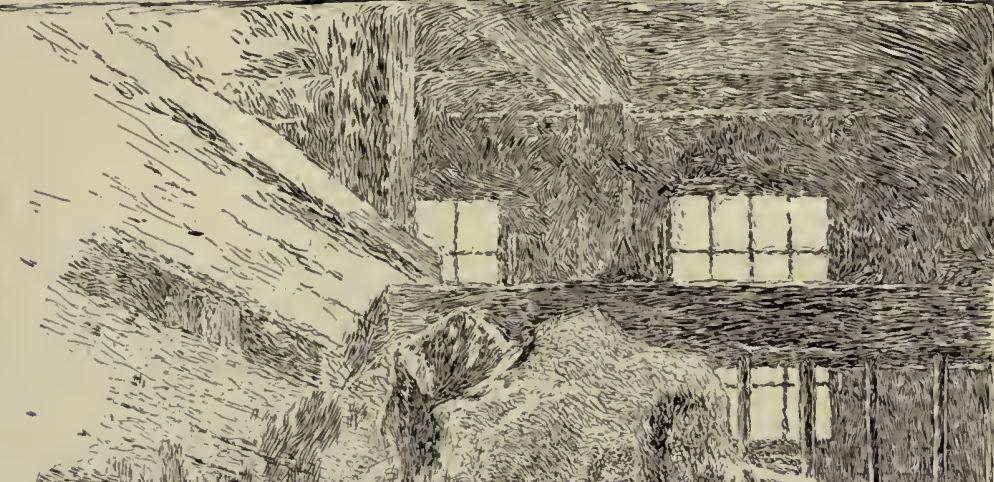

-

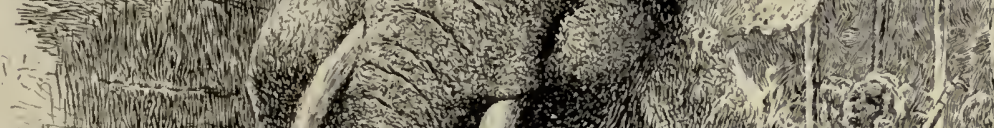

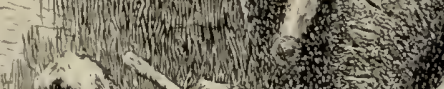

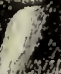
7.

If 1 in

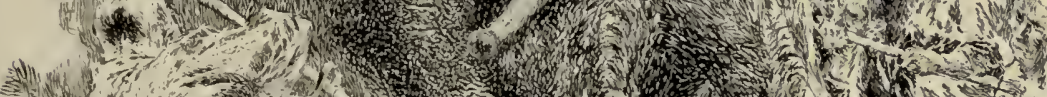

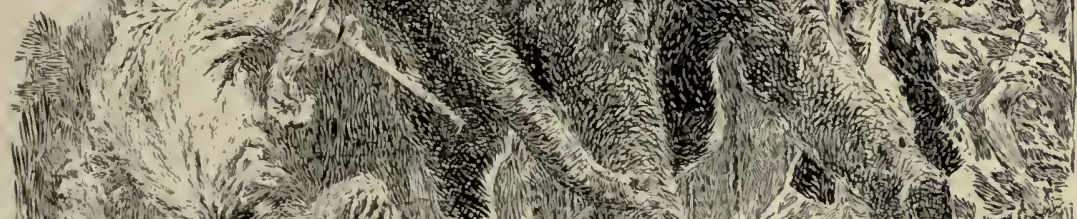

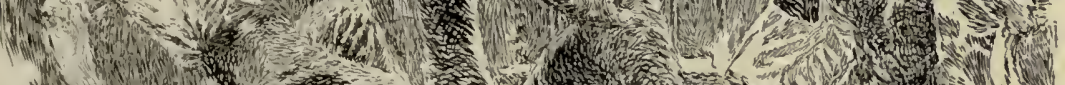

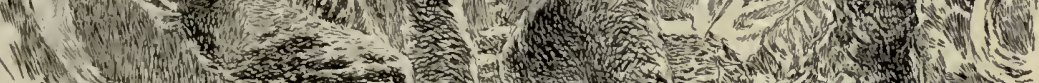

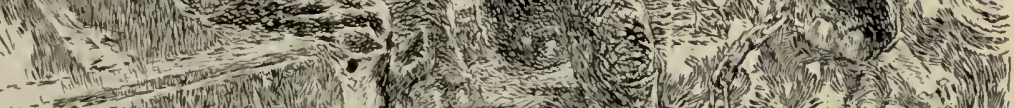

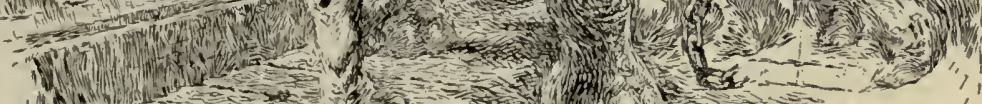
(11 (1) W

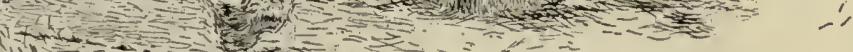

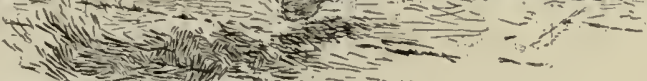

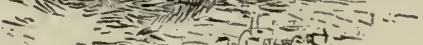
$-2=-10$

"I felt myself spinning so rapidly that the elephant, my men and the stall were all a blur; and I came up against the wall with a thud. Fortunately, there was a gutter running along the wall, and I dropped into it just as the elephant lunged forward at me." 

took care to thrust my hook always in the same spot, tearing a raw wound in his side, while the other men caught him on the legs and on the trunk. We had to work fast to keep away from the big trunk as it cut through the air, and his feet, when he kicked. Each of us was sent sprawling several times before the fight was over.

At last I could see that the elephant was paying more attention to the wound I was making than to anything else we were doing; he favored the hurt side and tried to shield it. Then, with a bellow, he knelt down and dropped on his side to cover the wound.

While I kept him down, Ali arranged the hobbles; then we petted him and allowed him to stand. He got to his feet doubtfully, as if he weren't sure that we were not playing a trick on him-urging him to stand up so that we could jab him again. The wound I had torn in his side was large enough for two fists, and it must have pained him terribly. He was worn out by the fight and he hobbled off to his new stall, much subdued. Several days later he came out of the "must" period, which rarely lasts for more than a week, and became again the docile elephant that took children on his back for a ride.

I went to see him several times before I returned to Singapore, and, when I entered the stall, he edged away from me, protecting his side. Years later, I went to Sydney and entered his stall. He didn't 
recognize me until I put my hand on the scar; then he muttered deep down in his throat and lay down. I petted him and fed him sugar, and he seemed to harbor no resentment against me, but he did remember me in connection with a strenuous and unpleasant afternoon. 


\section{SHIPPING WILD ANIMALS}

$\mathrm{E}^{\text {LEPHAnTS are easily trained and, when they }}$ once get the idea of what is expected of them, they will do it over and over with little variation. A trick or a certain kind of work immediately becomes a habit with them. In fact, they can form habits more rapidly than any other animals I have ever seen.

In Burma there are large lumber mills, and elephants are used for rolling the logs into position for the saws. Pushing with their heads, they run the logs up two inclined skids to the platform. Two elephants do the pushing and a third elephant acts as boss. The boss need not be an especially intelligent animal; he is simply taught that the log must go up the skids in a certain way and that the two pushers must be kept even. In his trunk he carries a few links of anchor chain, which he uses as a whip. If one elephant falls behind, the boss gives him a rap with the chain. When the log is on the platform, the pushers turn and plod back for another. The boss elephant is quite unimpressed by his authority, and the others show no resentment when he swings the chain on them.

When the whistle blows, the elephants know that 
it is time to stop work and eat. It makes no difference if they have a log within a fraction of an inch of the platform; the boss drops his anchor chain and gets out of the way, and the pushers step to one side, letting the log crash down again. Then, without the least expression of interest, they turn for the stalls. Because they obey signals so mechanically, the engineer steps out, when feeding-time comes, and looks up and down the runway to see if an elephant crew has a log on the skids. If so, he waits until it reaches the platform before he pulls the whistle-cord.

The great weight and bulk of elephants sometimes make difficult the problem of handling and especially of shipping them. They are usually hoisted over the side of the ship in slings, but that method takes much time and labor, not to speak of very strong tackle. I did not evolve a new one, however, until the refusal of the captain of one of the British India Steam Navigation Company's boats to take a consignment of elephants for me put my ingenuity to the test.

I was under contract to send fifteen large elephants to Madras, and I had arranged with the company's agent at Singapore for three shipments of five each. The animals were the remainder of the Trengganu herd and I was anxious to see them shipped, for I was still sick with the fever. The doctors had told me that the best thing I could do was to leave the country and recuperate, and any 
delay in disposing of the animals meant a great sacrifice of either money or health.

The first five elephants, together with attendants and food were waiting back of the sheds at Tanjong-Pâgar, the docks at Singapore, to be put aboard. At the last moment the chief officer came with the message that the captain refused to take them.

I went to the captain's cabin and found a stout, red-faced and apparently good-natured Englishman. He was just out of his bath, wearing pajamas and idling about in his cabin until the ship was ready to get under way. I thought it a good time to approach him, and I took care to be quite calm and cool about it, although I was raging inside.

I showed him my receipt and the bill of lading given me by the agent. He replied that the agent was not captain of the ship; he didn't care what agreement the agent had made. So long as he was captain, he'd run his ship to suit himself, and all agents could go to the devil, for all he cared. And, moreover, he'd not carry elephants-not for any one. I explained my position and told him that it would mean a great financial loss to me if I failed on my contract to deliver the elephants.

"Look here, Mayer," he said, "I've handled elephants at Calcutta and I've always had a lot of trouble with them. If I load these elephants, it means that I have to rig up extra gear, and I won't do it." 
"Captain," I replied, "I'll load those elephants without using a foot of rope. I'll put them anywhere you say, and you won't have to rig up a bit of gear. And I'll unload them at Madras the same way. Will you say the word?"

"I don't think you can do it," he answered, "but I'm enough of a sportsman to give you a chance."

That was all I wanted. I got out before he could ask me how I was going to work, for I couldn't have told him.

The elephants were to go in the bow and they had to be taken there through a seven-foot passage from amidships. The smallest of the elephants measured fully seven feet and the largest more than eight. I decided that we might as well try the largest first, and I asked that the electric bulbs be removed from the ceiling.

After some coaxing and prodding, we got the first elephant up the gangplank. The others followed obediently. Then I asked the chief officer to clear the cabins along the passage, for I was afraid that some one might open a door and frighten the elephant. A frightened, stampeded, eight-foot elephant in a seven-foot passage would give Singapore enough excitement to last for a year. The chief officer sent the people from the cabins and locked the doors.

The elephant balked at sight of the passage. I was at his head, talking to him and coaxing him, and two attendants were behind, prodding. We 
made him kneel and then urged him forward. At last we got him into the passage. It was a tight fit. His sides scraped the walls. I gasped at the thought of what would happen if he suddenly became afraid. He would try to stand up, of course, and then wedged in, he would begin to kick and lunge his way out; and the other four, who were close behind him, would do the same. "And then, goodby, steamship," I said to myself. Slowly we made our way forward, with the five elephants hobbling along on their knees. I stayed close to the head of the first, talking to him and petting him. Finally we came to the end of the passage, and I drew the first deep breath in fifteen minutes. I took the venture simply as a matter of course, and I didn't say anything that gave the captain an idea of what my emotions had been in that passage; but Ali looked at me and I looked at Ali, and there was no need of words.

I washed and went to the captain's cabin for breakfast, while the men secured the elephants in their quarters.

The captain said, "Mayer, that was the quickest and slickest thing I've ever seen, but what am I going to do with those animals at Madras?"

I knew that there were no docks at Madras and that all freight was unloaded into lighters, but I answered, "My men will attend to them."

When the ship reached Madras, the attendants opened the doors and simply backed the elephants 
overboard. They hit the water with a great splash and a roar and came up blowing like whales. They were swimming, of course, for elephants swim better than any other land animals I have ever seen. The attendants approached them in rowboats, and, jumping on their backs, rode them to shore. By the time they reached land, they had completely recovered from the excitement of falling overboard.

The captain returned to Singapore, enthusiastic over this new way of handling elephants, and I had the pleasure of shipping my last consignment to Madras on his ship. He advised me never to take an agent's word for what the captain of a ship will or will not do, and after that experience, I always saw the captain first and the agent second.

In collecting and trapping of wild animals one must not think that all animals so caught are fit for zoölogical or show purposes. Such is not the case; often after trailing animals for days and after having trapped them, I found them old, scarred, mangey, with broken tails and in numerous ways unfit, and although I rarely killed, except in selfpreservation, I would kill off all such as were not fit.

All animals I sold and shipped were at the time of embarkment, healthy, sound and in good condition. As I never carried with my outfit any preparation for the curing of skins, I usually allowed the natives to have them, although I often presented good specimens to the Raffles Museum at Singapore that were mounted and catalogued 
as donations from myself. In one exhibit a group of eight orang-outangs, from babies to full grown, and a baby elephant were well mounted and always came in for the particular notice of visitors.

I was having a busy week at my animal house in Singapore, getting a lot of animals recaged and ready for shipment to Melbourne, for Mr. La Souef, Director of the Melbourne Zoological Society, who was then on a visit to Singapore with his wife, when one day a messenger came from the Sultan of Johore, inviting Mr. and Mrs. La Souef and myself to call the following day.

As Singapore is an island of fourteen by sixteen miles, and separated from the main land by the Straits of Johore, the extreme southern point of Asia, or the Malay Peninsula, it really meant but a few hours, sixteen miles by rail to Kranji and by ferry across the Straits about a mile to Johore.

Back of the jail at Johore were built eight large, strong iron cages, in which were kept all tigers, leopards and smaller cat animals that were caught throughout the state of Johore and were sent to the Sultan for him to present as gifts or sell as he saw fit. I eventually had first call on all animals so caught.

On the following day, arriving at Johore, we were met my Dato Muntre, the prime minister, and introduced to Sultan Ibriam, who was at that time a young man and with whom I was very well acquainted. After showing Mr. and Mrs. La Souef through 
his palace and grounds, we came to the cages back of the jail, which contained three tigers, two black and one spotted leopard. The Sultan, pointing to one cage which contained a beautiful specimen of tiger, young, beautifully striped, and a bright golden yellow, said he wished to present that tiger to the Melbourne Society as a gift, and, turning to me said, "Tûan Mayer, you can get him whenever you wish," he knowing I was Mr. La Souef's agent.

Mr. La Souef was delighted and thanked the Sultan in his and the Society's name, promising to put his gift in a prominent place in the Melbourne Garden.

On our return to Singapore, I had quite an argument with Mr. La Souef regarding the flimsy, unsuitable cages he was having made to suit himself, and every time I ventured to point out the inadvisability of certain cages being built under his directions, he would invariably say, "Mr. Mayer, you may be right. I also am right, and I have handled animals longer than you." As the animals were his and he insisted on having his way, I simply carried out his instructions. His idea was to build large, roomy cages from the cheapest of wood (siraih), having a space between the floor and the cross section holding the iron bars, to clean out the cages and to hand in food.

I never would think of shipping an animal in such a cage. First it is too large and roomy, giv- 
ing the animal too much play to break the cage, and as it was weakened by having a space between the floor and the cross piece, unless made of heavy and strong wood. I always caged for shipping animals in small narrow cages or boxes; heavy wood; sides of wood, but bars at each end and no space. When wood or water was to be given them, the food was cut up small enough to be poured between the bars, and a drinking pan nailed to the floor of the cage. When cleaning out the cage on board the steamer, both front and rear covers were taken off and the cage flushed with water, at the same time giving the animal a bath. The bath in some instances, and according to the animal, would be dispensed with, but never with cat animals.

I returned to Johore the following day with a transporting cage, and with $\mathrm{Ali}$ and the assistance of a few of the prisoners from the jail, soon had the tiger safely boxed and on his way in a bullock cart to my animal house in Orchard Road, there to be reçaged in the cage $\mathrm{Mr} \mathrm{La}$ Souef was having built under his directions, by my Chinese carpenter who built all my cages. Taking me aside he said: "Tûan, etn, Orang bon-yer, gee-har sat-tu Jam remow pe-char" (Sir, that man is very foolish, the tiger will break his cage in an hour). I said, "Never mind, make the cage as he wants it, that is his look out."

Well, the cage was made, the tiger moved into it, and a few days later we loaded his shipment on 
board the steamer, ours being the last thing to be put on board. As the steamer was to sail at midnight, we had no trouble in placing the cages on deck, and, as space was limited, I suggested to Mr. La Souef to let me arrange the placing of cages and animals. But no, he would see to that, and told the captain that he would like to have them placed as he wished. They were on the forward deck, in a circle about the hatch, with the smaller animals and deer facing the cages on deck, on the hatch itself. Can you imagine placing deer in crates facing tigers in none too strong boxes?

I bade Mr. La Souef and his wife bon voyage, and wished him success in landing his shipment. Mr. La Souef was a personal friend of the owner of the steamship company, the McAllister line, who was a patron and also a director of the Melbourne Zoölogical Society. As Mr. La Souef had taken the trip with his wife as guests of the owner, Captain Edwards of the vessel used diplomacy, said nothing, and allowed Mr. La Souef to have his way; but before going ashore, I said to Captain Edwards, "watch out, there is going to be trouble before you get to Melbourne." "Never fear," he replied, "Mayer, I'll kill or dump the whole lot over the side if anything starts, friend of the boss or not! I have my other passengers to look to." I said good-bye to him hoping to see him on his return trip, when I would hear the news, if any.

The shipment consisted of the following, not 
counting the tiger, the gift of the Sultan of Johore: Two small orang-outangs, twenty monkeys, one sun bear, one honey bear, two civet cats, one binturong, four crown gora pheasants, one black leopard, one clouded leopard, spotted and looking like an ocelot, one female tiger, two samber deer, two mouse deer, in all fourteen cages and three crates.

At five o'clock the following morning, I was awakened by a hammering at the gate and the calling of "Tûan! Tûan!" Looking out, I saw a native boatman. "What do you want?" I called.

"Tûan, etu re-mow, pe-char sanken, mon lorrie" (Sir, the tiger has broken his cage and wants to run away).

"What tiger? Where," I asked.

He said, the tiger from the steamer.

"Well, what do you want me to do? The steamer left last night. I am through with it."

"Te-dar Tûan" (No, Sir), he said, handing me a letter, "the tiger is in my lighter and is tied to one of the buoys in the harbor." He begged me to get the tiger, as no one was near or on the lighter.

The letter, which was from Mr. La Souef, written before the steamer sailed, stated that the tiger presented by the Sultan of Johore had broken his cage and was in danger of getting clear away, as the captain had had a sling put about the broken cage after the ship's carpenter had nailed a few boards to cover the hole the tiger had made and partly strengthened it, hung the cage over the side 
of the ship, telling Mr. La Souef that if he did not get some kind of a boat or lighter to put the cage in, he would drop tiger, cage and all into the water, and as this happened at about half-past eleven at night, things did not look very bright for Mr. La Souef. He begged and prayed the captain to let the carpenter or himself get nails and boards, but the captain was firm. They finally got the head stevedore of the dock to let him put the cage in a lighter, which they did, and then towed the lighter out in the harbor, everyone leaving it as soon as it was tied to a buoy, and Mr. La Souef then told them to notify me, which they did. There I was, with instructions to get the tiger, recage it and ship by next steamer, eighteen days later.

I asked the boatman where the lighter was. Taking Ali and four natives with ropes, boards, nails, etc., we werit down to the docks, and there out in the harbor tied to buoy was the lighter with a fleet of small boats surrounding it at a good distance. I called a sampan and told the owner of the lighter to follow. As we neared the lighter, we could hear the growling and the tearing of wood, and getting alongside and cautiously climbing up, I looked in.

There was the cage with the tiger's head through a hole that it was trying to make larger. Fortunately the cage had been strengthened by the ship's carpenter, otherwise he would have broken out and escaped before I could have been notified. By that time the docks were lined with people. The story 
had spread that there was a lighter in the harbor, filled with wild animals that had broken out of their cages and were fighting and killing one another and those that could escape would jump into the harbor and make for the shore. Then some one called Police Headquarters and four European officers came down to the dock with repeaters.

Ali and I dropped into the lighter, calling to the natives to pass the boards, nails and hammers, and assuming that there was no danger, we took each an end of a board and carrying it to the top of the cage passed it over until it covered the hole the tiger had his head out of. As Ali and I held the board my men nailed it and then another, so soon we had him fairly well secured; that is, he was in the cage again, snarling, biting and scratching. Calling to the owner of the lighter to come aboard with his men and row his lighter to the docks, we went to work and nailed board after board against and over all weak spots. There was no need to tell the boatmen to hurry; they never rowed faster. Arriving at the docks, and after telling the inspector just what had happened, we got the cage on a bullock cart and soon had the tiger safe at my animal house. Three weeks later I shipped him aboard in a good strong cage, in charge of the captain, but as the steamer was steaming up the Yarra river into Melbourne, the tiger died. An autopsy showed he died of a fractured skull, and later I got the full particulars. 
It seemed that when the tiger first attempted to break out of his cage on board the steamer and the carpenter was ordered to get some boards and cover the hole he had been tearing, as the head showed against the opening the carpenter struck it with his hammer. The deer and smaller animals became terrified, and in their endeavor to escape, the deer's legs got through the slats in the crates; they broke their legs and had to be killed. This I was told later by Captain Edwards, who said it all happened within a few minutes, Mr. La Souef running about like a madman, begging this and that, getting in the way of everybody, but no one paying any attention to him, and what with the excitement among the passengers, the roaring of the tigers, barking of the bears, chatter of monkeys and crying of the smaller cats, and the frantic efforts of the deer to break through the crates, he was only adding to the confusion and disorder, until Captain Edwards ordered the water hose brought into play to quiet the animals. He told the carpenter to get some boards and nail up the opening the tiger had made, then having a sling put about the cage with the tiger snarling and biting and tearing at the opening it had started, but now covered by the planks, swung it over the side of the ship and there it hung. The captain then had the cages taken off the hatch and placed against the side of the steamer, telling Mr. La Souef that if he did not keep quiet he would have 
the whole shipment put over the side and dumped into the harbor.

That was the story Captain Edwards told me on his return trip to Singapore, and he laughed heartily over the way he said Mr. La Souef was hopping about in his pajamas.

My bill against the Society for services, paying for the lighter the tiger was put into from the steamer, labor, recaging, feeding for twenty-one days, and enough food for eighteen to twenty-one days' voyage to Melbourne seemed to Mr. La Souef an overcharge and my bill of $£ 50$ all out of proportion; as the tiger was a gift from the Sultan of Johore and not purchased. I insisted and drew on him for that amount, at the same time resigning as agent for his society, telling him that although he was an older man, he had still to learn the art of caging, recaging and shipping animals, not receiving them, and that had he not insisted on having things done his own way with cheap material, and had left it to me, what happened could not have happened, as barely one-third of his shipment landed alive.

By the time I had disposed of the last of my elephants, I was so sick with the fever that I could not leave my bed. I was dangerously ill and I began to realize that I should be lucky if I escaped with my life.

Mr. Lambert, who had been my friend ever since I landed at Singapore to enter the animal business, engaged passage for me on a steamer bound for 
Europe and took charge of the affairs of my animal house in Orchard Road. When it was time to go to the steamer, my Chinese coolie boy carried me. $\mathrm{He}$ is the only Chinese I have ever seen cry; the tears rolled down his cheeks as he carried me up the gangplank and to my cabin, for he thought that he should never see me again. I rather thought so myself, but I figured that if they didn't drop me into the Red Sea, which is the last resting-place of so many people who have stayed too long in the tropics, I should recover and live to return.

Ali and the coolie waited faithfully for me during the next year, while I traveled in Europe and America, recuperating and gathering new commissions for animals. And, when I came back, they were on the dock to welcome me.

Though my health was much improved by the voyage I did not feel able to resume the active business of collecting, and so I concentrated my efforts upon my animal house and made it the largest place of its kind. I had a monopoly of the business. Mahommed Ariff, who had a large number of native collectors working for him, did much of his dealing through me, and I had no difficulty in disposing of all the animals brought in from the jungles by our various agents. My largest market was Australia, where I could sell the animals f. o. b. Singapore without any of the risk of transportation. Also, I made shipments to Hagenbeck, of Germany, and Cross, of Liverpool. Because of the high 
import duty, I sent comparatively few of my animals to the United States.

John Anderson, who was European adviser to the King of Siam and who had been created a Siamese nobleman, sent for me and offered me a commission that kept me busy for the next five years. The King of Siam was in the habit of making presents of wild animals to foreign rulers, and it became my work to select the animals and supervise all details of shipment. I was sent to interview the Minister of the Interior, H. H. Prince Damerong, who gave me a permit to travel wherever I pleased in Siam and to force labor. In Siam, I directed many hunts, especially for tuskers to be used in the teak forests. The driving was done entirely during the daytime, and on elephants, instead of on foot, as in Trengganu. The fever had left me in bad condition, and so I did not take an active part in the work.

On my trips between Bangkok and Singapore, I stopped off many times at Trengganu to renew my acquaintance with the Sultan and to talk. with the native hunters, who were sending a steady stream of animals to me at Singapore. I was known to the natives throughout the Peninsula as Tuan GâjahSir Elephant-and I was amused to find that the story of the big elephant hunt had grown to incredible proportions. The herd of sixty elephants became larger each time the story was told.

After one exciting incident in the work of shipping animals for the King of Siam, I was allowed 
full authority. We were sending a pair of beautifully matched leopards to the Emperor of Austria, and they had reached Singapore in two large, poorly constructed cages. Mr. Anderson was there, and we disagreed on the advisability of recaging them. I thought that the cages looked weak and I wished to have my Chinese carpenter build two that would be smaller and stronger. Mr. Anderson, however, was impatient to start the leopards on their voyage, and, since he was boss, we loaded the cages on bullock-carts and headed for the docks. In unloading one of the bullock-carts, the natives allowed the case to slide to the ground too heavily; the cage broke, and out went Mr. Leopard like a flash of lightning, heading straight for the Chinese quarter. The Chinese saw him coming, and a panic started. They tumbled over one another in getting out of the way, and two of them were scratched. The leopard was quite as frightened as any of the Chinese. The natives in charge of the bullock-cart came running for me, and I went to the Chinese quarter to find the leopard. He had taken refuge in a house, and I finally discovered him hiding under the stairs, his eyes shining in the darkness. Since it was impossible to get rid of the mob of Chinese and recaging under. the circumstances would have been too dangerous, we had to shoot the animal. We took the other leopard back to Orchard Road and built a new cage.

In 1902 , just before the rainy season, I was rest- 
ing in Singapore after six months of hard work. Just as I had almost decided to go to Europe, I happened to see in an old copy of the New York Clipper an advertisement of a steam merry-go-round. That gave me an idea; there had never been a merry-goround in the Malay Peninsula, and I was confident enough of my judgment of Malay nature to gamble that it would be a success. Mr. Lambert didn't agree with me. "Forget about it," he advised. "Take the steamer and have a good vacation." But I went to the Hongkong and Shanghai Bank and cabled $\$ 2,000$ in gold to the factory at North Tonawanda, New York, with instructions to ship me the merry-go-round on the first boat, via London. It arrived nine weeks later, and it cost me $£$ IIO in freight. The rain was beating down steadily in Singapore, and so I transshipped it to Penang.

A few days later, I was in Penang, driving around in a rickshaw, looking for a good location, while the merry-go-round, still in crates, was coming ashore in sampans. Opposite the Hotel de la Paix I found a good open space, and I routed out of bed the Chinese merchant who owned it. I told him that I should like to rent the lot for a show and that, if he would come to terms with me, I would let him and his family ride free of charge. Now a Chinese likes a show better than anything else on earth, and so we were not long in closing a bargain. I was to pay him a rental of \$I Mexican a day and to have an option of two months on the lot. I had no 
paper on which to write out the agreement, and so, since I didn't want him to change his mind, I paid him \$30 for one month, writing the receipt in my pith helmet. He signed in my hat; then we pasted a stamp in it and canceled the stamp by writing the date across it.

While Ali and my coolie boy were getting the merry-go-round unloaded, I collected a gang of laborers and an engineer. All that day we worked at uncrating the merry-go-round and putting it together. The natives stood around, watching us and speculating as to what this strange new thing could possibly be. The merry-go-round ran on wheels on a track and the horses were connected with eccentrics, which worked them up and down; a good loud organ was connected by a belt with one of the wheels. The merry-go-round carried fiftysix people.

I began business on the Chinese New Year's Day. The merry-go-round was the sensation of Penang. The crowds flocked to see it, and the natives lined up for several hundred yards, each with his dime in his hand, waiting for his turn. We were so busy that I could not even go to the hotel for a meal; the brassy organ of the merry-go-round shrieked from early in the morning until late at night. In two days, I took in $\$ 1,500$ Mexican.

On the third day the merchant from whom I had rented the lot announced that he was going to build a fence around it and charge two cents for the priv- 
ilege of standing and watching the merry-go-round. I told him that I wouldn't allow it; that all of Penang could come and see my show free. I was too busy taking in dimes to think about fences. He went away angry and disappointed. Four days later a lawyer representing him came to see me. He said that the rent had been raised to \$ro a day, and that a dispossess order would be executed unless I paid it. I told the lawyer to wait and I went back to the hotel, to get my pith helmet.

The merchant had forgotten about the receipt. When the lawyer saw it, he told me that the merchant was unpopular with all the Malays and Chinese in Penang because he cheated them, and that they would be delighted if I sued for breach of contract. The result was that, for \$I a day, I got the use of the lot as long as I wanted it.

Within six weeks I had made up the entire cost of the merry-go-round and I was on velvet. The dimes were still rolling in as fast as I could collect them. Finally, when the novelty of my show had worn off and business began to slacken, I shipped to Rangoon, Burma, to collect dimes there. After the merry-go-round had been running two weeks, I was approached by a man who wished to buy me out. I had had all the fun I wanted, and so I sold it to him for 10,000 rupees $-\$ 4,500$ in gold. He was a government official and consequently did not wish to appear in the transaction. The bill of sale was made out in his wife's name, and a man was hired 
to run the merry-go-round for him. I stayed for a week to get the enterprise started; then I went up to the lumber mills to see if the lumbermen needed elephants. When I returned to Singapore, I had a commission for six large elephants.

It was a better vacation than I could have had in Europe. I had made many friends and attended to some animal business and I had $£ 700$ clear profit in my pockets.

At my animal house I found a letter from Mr. La Soeuf, the director of the Perth Zoölogical Gardens, saying that he was anxious to get a rhinoceros and asking what I could do for him. I did not want to go into the jungle again immediately, for I was afraid of a return of the fever, but I replied that I would see what could be done and I sent out word to all my native agents. Both Mr. La Souef and his father, who was director of the gardens at Melbourne, were great friends of mine, and their gardens had been my best market for animals. Quite naturally, I wanted to do everything I could to help them, and so, when word came from an agent in Trengganu that some rhinoceroses had been located there, I packed up my kit and started out.

At Trengganu, the Sultan welcomed me, and I spent several days with him, telling him what was happening in the world and discussing his problems. The problems were largely financial. He owed some money, and, knowing that he had something 
in the treasury, I asked why he did not pay his debts.

He thought for a time and then replied: "Well, I'll tell you. If I pay those people, they will forget about the Sultan of Trengganu. If I don't pay them, they'll never forget me."

The conversation turned to the subject of prisoners. On my way to the palace I had passed the cages where the prisoners were kept. Many of them were starving to death, for, unless their friends or family cared for them, they got no food. "Why don't you feed them?" I asked.

"Why should I?" he replied. "If I feed them, my whole country will want to go to jail."

Finally, after he had satisfied his craving for sociability, he gave me my official permit to go into the interior and to force labor. I started out for the upper end of his state, bordering on Lower Siam. At the mouth of the River Stû, I found my agent; we gathered a crew of ten men and went up the river as far as we could. When the weeds became so thick that we could not force the boats through, we took to the jungle and began cutting our way to the mud-puddle where the rhinoceroses came to wallow.

We took great precautions in approaching the puddle, for once a rhinoceros gets the scent of a hunter, he is off through the jungle as fast as he can go. The hunter, who spots his animal and shoots, has an easy time of it; but the collector, who 
must capture, has a more difficult job. He must work and build his trap at the very spot frequented by the animal and he must do so without exciting suspicion. A rhinoceros seldom charges when he sees a man, and his charge is not dangerous, for he is short-sighted and cannot gauge his direction accurately. Most often he runs, and it is almost impossible, even when the collector can find him again, to chase or lure him back to the trap.

No animals were at the puddle when we arrived, and I had a good opportunity to examine the location. Then we withdrew and I told the men how we should go about making the capture. We made camp, building platforms between the trees for living-quarters, and I detailed some of the men to the work on a rattan net, which measured twenty by fifteen feet, with meshes ten inches square. I felt that we had a good chance of getting a rhinoceros in a net-trap and should save ourselves much time and labor if we could do so. When the net was ready, we put it in position at a likely-looking approach-half on the ground, where the animal would step into it, and half suspended, so that he would catch it with his head and bring it down about him.

Then we turned our attention to making pits. As I have explained before, a heavy animal was sure to injure himself in falling into a square pit such as the natives generally dug, and, of course, an injured animal would have been of no use to me. 
Hence the four pits that we dug around the puddle were made wedge-shaped, instead of square. They were six feet wide at the top and tapered to three feet at the bottom; they were eight feet deep and ten feet long, with the approach tapering down so there would be the least possible chance that the beast would injure himself when he fell.

Over the tops of the pits we built platforms of bamboo poles, and covered them with mud and leaves, taking care to leave no traces of our work. To the building of each pit we gave a whole day of hard labor and we were constantly on the alert for fear one of the rhinoceroses might surprise us. Lookouts were already stationed to catch the sounds of the beasts as they broke through the jungle, coming to their bath.

One morning a native came running with the news that a rhinoceros was trapped. We gathered our tools and hurried off to the puddle. There, grunting and fighting, lay a two-ton rhinoceros, firmly wedged in and helpless. When he saw us, he became furious, squirming in the slime of the pit, pounding with his feet and grunting.

I divided my crew, putting half at building a cage of heavy timbers and the others at digging away the ground in front of the beast. By the time the cage was put together and bound securely with rattan, we had an incline running down to the pit, with two feet of earth walling the rhinoceros in. Then we placed skids on the incline and let the cage 
slide down. A native, who had been sent back to the nearest kampong, or native village, to recruit men and water-buffaloes, had soon returned with a score of other natives, driving six water-buffaloes before them. Then I went through the usual business of holding a meeting and explaining carefully, in the greatest detail, exactly what we were about to do and how we were to do it; what each man was to do and when and how. When they understood perfectly, we set about digging away the wall that separated the rhinoceros from the open end of the cage. With a little more than one foot of earth remaining, we began to prod him. The immense beast pounded his feet on the bottom of the pit, grunting and moving forward as rapidly as he could get foothold. He put his head against the wall and rooted; the wall toppled over and he lurched out of the pit and into the cage. The natives slipped the end-bar into place.

The capture was finished-but not the work. A rhinoceros cannot be broken and driven through the jungle like an elephant; he must be hauled every foot of the way. With the six water-buffaloes straining and every native giving a hand, we pulled the cage up the incline and mounted it on the runners. It took a week of steady cutting to clear the way, so that we could drag the cage to the Trengganu River. There we built a heavy raft and floated the cage down to port. Another two weeks 


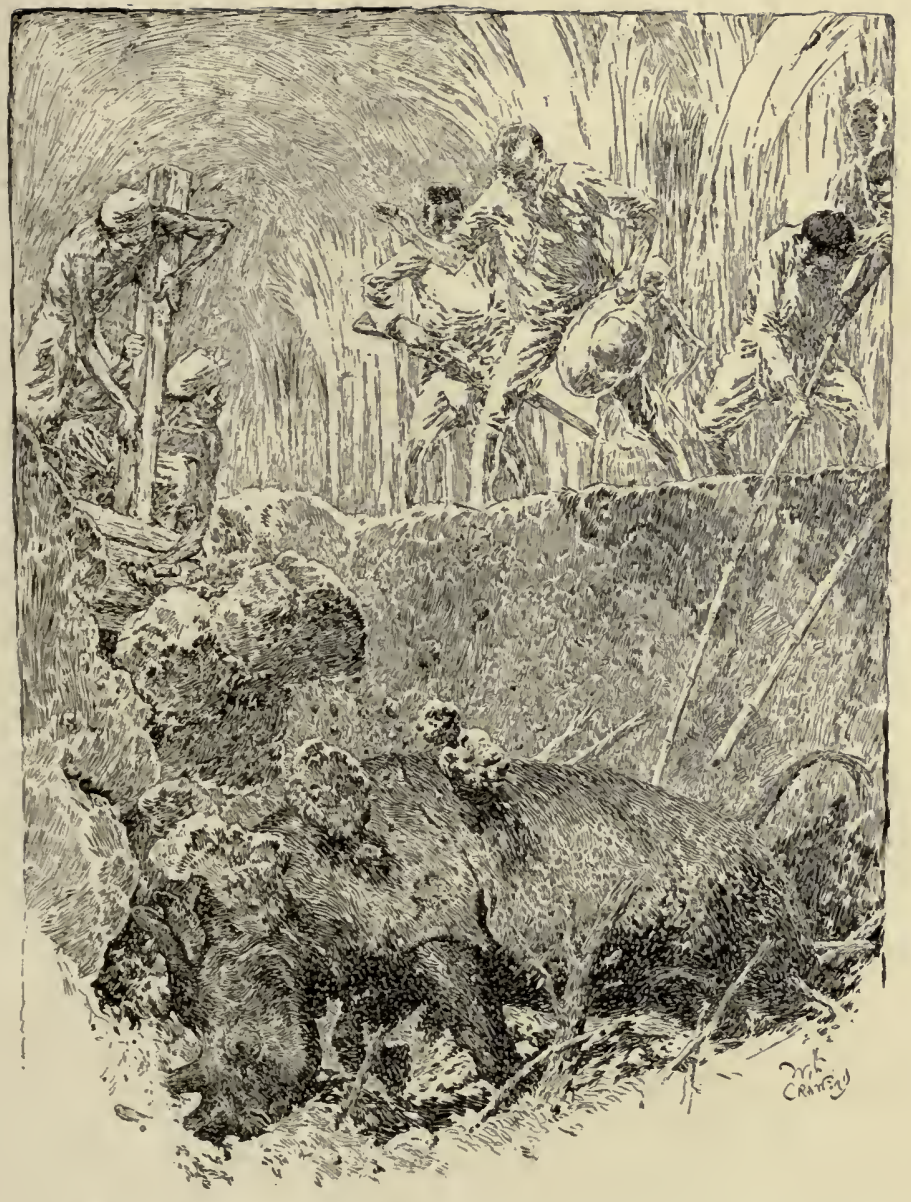

"We began to prod the rhinoceros. . . . He put his head against the wall and rooted; the wall toppled over and he lurched out of the pit and into the cage." 

passed before we could ship the beast to Singapore, for transshipment to Perth.

I received for the animal $£ 200$, which was about one quarter of its value. But it was as much as the Perth Zoölogical Gardens could afford to pay, and I was glad to be able to put so fine a specimen into the hands of Mr. La Souef.

One day when I was busy in my animal house, Ali came to me with the message that three natives from Pontianak, Borneo, were outside. They had something important to tell me, Ali said. When they came in, I found that I knew one of them; he was an animal trader from whom I had bought some birds and monkeys. The other two were headmen from the interior of Borneo.

The headmen had gone to the trader with the story of two large orang-outangs that were terrorizing their villages, and the trader was bringing them to me for advice. We sat down in the shade and discussed the situation. The orang-outangs had run off with a young girl and had recently killed one of the men. The natives had tried repeatedly to kill them, but without success, and now they were afraid to venture into the jungle.

For several years I had had a standing order from the Antwerp Zoölogical Gardens for a good specimen of orang-outang, and I had planned to go, just as soon as my health permitted, into Borneo, to see what I could find. Orang-outangs command unlimited prices because they are so hard to cap- 
ture and, once captured, so difficult to deliver. On account of homesickness and sensitiveness to climatic changes, they die quickly in captivity. A caged orang-outang loses his spirit immediately; he sits brooding over his capture and often refuses all food. On one occasion I shipped eighteen small and medium-sized orang-outangs to San Francisco, hoping to land two or three alive, but they all died before reaching port. If I had been able to deliver a good specimen in the United States, I could have sold it for $\$ 5,000$.

But here were two full-grown beasts, already located, and waiting for me to try my hand at capturing them. I was greatly interested in the story the two headmen had to tell, and I spent the entire afternoon in listening to them and asking them all manner of questions. They described the country where the orang-outangs made their home, and promised as many men as I needed.

I impressed them with the fact that I was not anxious to make the trip, and I made them promise, as a first consideration, that they would use all their power to prevent the natives from killing the animals if I captured them. I feared that the resentment of the natives against the orang-outangs might lead them to kill the animals for revenge, even after I had them safely caged. They agreed to do as I requested and once again begged me to return with them. I told them to come back the next day and talk with me again. I had already 
made up my mind, but it is always well to let a native think that one has not quite decided.

When I went to see the Dutch Consul-General and explained the situation, he issued passports for me, and, accompanied by the two headmen, the trader, Ali and my coolie boy, I took the next steamer to Pontianak. At Pontianak, I presented my credentials to the Dutch Resident. He was pleased to hear that I was going after the orangoutangs and he offered to let me have as many native officials as I wished to take along. I thanked him and declined his offer, explaining that I really did not know as yet just what I should need, or how long I should be up-country. As a matter of fact, I did not want his native officials because I knew that the jungle people have no love for them, and I wanted to have my expedition entirely clear of everything that looked official.

We stayed there for several days, getting supplies together. The trader remained with the party at my request, because he was known by both the coast and the jungle people. From a Chinese he rented a houseboat that I could keep as long as I had need of it. The Borneo houseboats are twenty to twenty-five feet long and five feet wide; they have a bamboo shed, which makes a fairly comfortable room, and are rowed or paddled by six men. With a mattress spread on the floor and mosquitonetting hung about, I could take the trip up the river easily. Omar, one of the headmen, stayed 
with me in my boat, while Mahommed Munshee, the other headman, went ahead with some of the stores.

On the way up the river we came to the station of Dr. Van Erman, the Dutch medical officer who was in charge of the outlying districts. He insisted that I stay with him for two days at least, and I was glad to do so, for he was the last white man I should see before we tackled the orang-outangs. I was anxious to have the benefit of his knowledge of the natives and the country, and also I found it reassuring, under the circumstances, to have the friendship of a medical man. Later, I became his enforced guest and I have always been thankful for his care.

We arrived at Nanaoh-Pinoh, which was Mahommed Munshee's village, two days late. I stayed at Munshee's house while the men prepared boats for the trip up the Melarir River to the spot where the orang-outangs were. 


\section{V \\ THE SEA TRAGEDY OF THE JUNGLE FOLK}

$\mathrm{I}^{\mathrm{T}}$ seemed to me, as I waited in Mahommed Mun1 shee's village, that it might be a good plan to establish a reputation among the natives as a worker of wonders. Fame as a magician is easily acquire among these people and is of inestimable value in handling them. For the task that lay before us, I needed all their courage and confidence, and I had a feeling that they were accepting me with some doubt. That would never do, for, unless I had them under perfect control when the hunt reached its most exciting point, all our efforts might be wasted. They showed proper awe of the express rifle that Ali exhibited so proudly, and they took fitting note of my stores, but still they regarded me simply as a white man who might, or might not, be able to do the things he said he was going to do. They were respectful and hospitable, but the more I saw of them, the more I realized the importance of doing some spectacular thing that would distinguish me in their minds and send tales of my magic traveling through the wilderness of jungle. It is astounding, by the way, how rapidly 
news travels in the jungle. Many times, in breaking through virgin country, I have found that the news of my coming had preceded me and that the natives knew all about me and were waiting for me. The only explanation I could ever get was simply, "Tûan, we heard."

A good opportunity to impress the natives presented itself one day when I was preparing to take a plunge in the river. Munshee stopped me, saying: "Take care, sir. There are crocodiles in the river." He told me that many natives had lost their lives recently and that men had had their arms snapped off while they were paddling boats.

I took his advice and went to the house where my supplies were stored. Presently I returned with a stick of dynamite and a fuse. Gathering the natives around me, I explained to them that they were to line the banks of the river and prepare to come out in their boats when I gave the signal. They were entirely mystified, for they had never heard of dynamite.

Going up-stream, I prepared the charge and then drifted down, dropping it over. Wide-eyed and puzzled, they watched the smoking fuse disappear into the water. Then came a muffled explosion, which made them jump; the water trembled, shaking the boats and frightening them; fish came to the surface. I signaled and the scramble to gather the fish began.

Ali was standing near me, ready to put the rifle 
into my hands, and I strained my eyes, looking for crocodiles. Suddenly a woman pointed to the opposite bank and screamed, "Buâia (crocodile)!"

I yelled to Munshee to take his men down-stream and keep them quiet and on the alert; then I directed my boat above the spot where the woman had pointed. I dropped another stick of dynamite overboard. A few seconds later, the belly of a crocodile appeared on the surface, its feet and tail moved feebly. It was stunned by the explosion-mâbok (drunk), as the natives say

I took my gun and put two bullets into its belly. Before it could sink, Ali grabbed its tail; then we made for the shore. The natives gathered about, wildly excited, and Mahommed Munshee was the proudest man in the village. He had vouched for my abilities and I had proved my possession of the powers that he claimed for me. It was hobat-an (magic).

The crocodile measured fifteen feet, four inches, and was twenty-five years old. The natives could tell its age by counting the pebbles in its pouch.

I decided to stop at Munshee's a few days longer, to have the men gather rattan to make the nets, and also to talk with the natives about orangoutangs and plan all the details of the capture. Omar, the other headman, went on up to his village, taking with him as much of our store of provisions as he could carry. I was willing enough to have him spread the crocodile story among the 
natives and I knew that the tale would not suffer in the telling.

Omar was to determine, if possible, the exact location of the orang-outangs and to make arrangements, such as engaging recruits for the hunt, in advance of my arrival. I planned to have a general council of all the men who were to take part in the work. Such a council would have a double advantage: in the first place, it would give me the benefit of their experience, and secondly, it would make them feel that I depended upon them.

It took us four days to gather as much rattan as we could carry in our boats; then, with thirty men, we started up the river. I found at each village that Omar had done more than justice to the crocodile story and that he had taken with him a select crew of men. As in Trengganu, the natives felt that this was to be the great sporting event of the year, and they were anxious to take part. Their keen interest in the adventure made it possible for us to choose the strongest and best of them, together with a few older men, who knew the jungle.

Our boatmen swung on their paddles steadily, pushing the boats against the current. Solid banks of foliage lined the sides of the stream, and, in places, the branches touched overhead, making a thick canopy that shaded us. In the sun, the heat was blistering.

When we arrived at Omar's kampong, the entire 
population was on the banks to welcome us. Omar came forward and announced that he had recruited seventy men-Malays and Dyaks-for the hunt and that he would vouch for all of them. That made a crew of a hundred, counting the thirty who came with me, and we examined one another curiously. I was the first white man that most of them had seen.

Leaving instructions that the council was to be called for the next morning, I went to the house that Omar had prepared for me. Afi and the Chinese boy accompanied me with my personal equipment, and I sat talking with Omar while I waited for my bed to be prepared, so that I could get my afternoon nap. The men loitered outside the house apparently waiting for something. I knew what they wanted-more magic. At last a deputation came with the request. Would the white man perform magic such as he had performed at the village of Mahommed Munshee?

Crocodiles were less plentiful so far up the river, and I was rather afraid that they might be disappointed if I did not at least equal the former exhibition. The story, as I have remarked before, had grown wonderfully in traveling up-country. But they were determined to see the "drunken fish," and I decided that, before beginning work, I should do well to give them some sort of amusement.

With the two headmen-they were delighted to 
show such familiarity with this new sport-assisting me, I stationed the natives on the banks with their boats and then I went up-stream with the dynamite. There was breathless silence as they saw me strike a match and touch it to the fuse. When the explosion came, they gave a shout and darted out in their boats to gather in the fish. After the excitement had subsided, and all the fish had been compared for size and weight, I dropped another stick. The men enjoyed the sport immensely, and we made a hilarious afternoon of it. The most sober person in the village was my coolie boy, who, as he went quietly about his business of arranging my living quarters, muttered, "Sěmûa gîla (All crazy)."

Ali, who had become a good shot, showed the villagers my express rifle, and demonstrated what an explosive bullet could do to the trunks of trees. The men were fascinated by that power of destruction, and they passed their fingers reverently over the barrel and listened to Ali's stories while he cleaned it. Ali had traveled all over the Far East with me and he gave marvelous interpretations of what he had seen. He could hold an audience of natives spellbound for hours and, incidentally, he was an excellent publicity man for me. In his whole-hearted, childish, Malay fashion, he accepted me as the greatest man in the world and he was never contented unless others did so too. He was in great measure responsible for the success 
of my expeditions, for he removed many an obstacle -sometimes without my knowledge-and worked constantly to keep up the enthusiasm of the men.

I wanted the council to be a formal affair, and so I had Omar sound the call by striking on a hollow log. The older men took their places first, squatting in a semi-circle; then the younger men squatted behind them. The women and children loitered on the outskirts at a respectful distance. All of them were chewing betel-nut.

From the house, I watched the council assemble, but I did not go out until Omar came for me. Then, with Omar and Munshee walking beside me, I left the house, dressed in native costume-Chinese trousers, sârong and jacket. The chattering ceased as I approached, and all eyes were centered on me. Every one was visibly impressed by the fact that I was wearing the clothes of a native, and that they were of the finest quality, and entitled me to much consideration.

The importance of staging such an expeditionall the "magic," the talk, the council and the costume- was not to be underrated. As I have explained before, the natives are extremely impressionable; if they like a man and believe in him, they will do anything he asks, and if they do not believe in him, they will run wild at the moment when he needs them most. The orang-outang hunt was the most important and difficult thing of its kind I had ever attempted; it required the greatest technical 
proficiency, because there were numerous chances of failure through little miscalculations. Elephant driving is, after all, largely a matter of simple strategy combined with endurance; and capturing leopards is about on a par with setting mouse-traps when compared with getting full-grown orangoutangs into cages.

I squatted before the council and talked long and earnestly about the work that lay before us. I told the villagers that I had left important business in Singapore at the request of their headmen, to come and help them; that I had hesitated about making the trip and had been persuaded only by the promises of Omar and Mahommed Munshee that every assistance would be given me. I explained that I had the permission of the Resident-General and that he had offered me men, but that I had refused, because I knew I could depend on the men of this kampong-they knew everything that was to be known about the jungle, and the whole world knew that they were brave and cool-headed. I impressed upon them that such work was not to be taken as play, and that it was a dangerous enterprise. The natives nodded sagely. "You must be guided by what I say and do," I told them, "for I have made plans. If you do as I tell you to do, we shall be successful."

Then I called upon the men who had been sent out to locate the orang-outangs. They had found them about two hours' distance from the village; 
they described the location and told how it could be reached. A general discussion followed. I gave each man a chance to express his ideas. They all wanted to talk-preferably all at the same timeand the council dragged on for hours. With the assistance of Omar, I kept the debate orderly, and we listened to all sorts of opinions.

For the most part, they felt that it would be necessary to kill the animals. That, of course, was the last thing in the world that I wanted. It would mean that the expedition was wasted effort: there are few live orang-outangs in zoölogical gardens, but many stuffed ones in museums. I did not agree with the idea that we should have to kill the animals but I did not entirely disagree. We compromised by reaching the decision that, if they must be killed, I should do the work and no man should try to kill them without my consent. The natives had seen what one bullet from my rifle would do to a tree, and they were convinced that an orang-outang would stand a poor chance.

The council broke up and work began. I had Omar set some of his men to making strong nets of twisted rattan. He drew plans for the two cages and had other men gather the limbs of trees for them. The cages were just large enough to hold the animals and small enough to keep them from getting any leverage on the bars. After the skeletons of the cages were built, they were bound tightly with rattan ropes so that, even if the bars were 
broken, the orang-outangs would be in a network.

The strength of a full-grown orang-outang is enormous. I have seen one bend a one-inch steel bar as though it were made of rubber. If he can brace himself properly, with plenty of room to exert his entire strength, he can bend almost anything; but between bending a bar and breaking a rope by pulling, there is a great deal of difference. A rattan rope will hold him, though a simple menagerie cage may not give him anv more trouble than a paper hoop.

The strength of the orang-outang, or "wild man," as the name means in Malay, is largely in his arms. The arms of a mias-the breed that we were after-measure ten feet or more from tip to tip. The mias type, which is next in size to the gorilla, is somewhat larger than the ordinary breed. It is distinguished by a darker color and by folds of skin at each side of the face. Its body, from shoulders to hips, is about the size of a man's. It has short, undeveloped legs, long fingers and thumbs that are mere stubs.

An orang-outang never travels on the ground when he can swing from tree to tree, since there are very few open spaces in the jungle, he seldom reaches the ground except when he goes down to get something. He can swing incredible distances, hurtling through the air and catching branches with perfect accuracy.

Orang-outangs usually live in colonies number- 
ing from forty to sixty, and the largest and most powerful is chief. They make their homes on platforms by breaking off limbs and putting them crisscross. In mating season the male and female live together, but the couples separate after the young are born. The mother takes care of them and the father goes off about his business.

As they do in the case of most dangerous animals, the native collectors hunt orang-outangs by killing the mother and taking the young. The weapon they most often use, except when they have guns, is the blow-pipe, which, in the hands of an expert, is not to be despised. It is a long, slender tube, measuring from six to eight feet, made from a single joint of a rare bamboo. The tube is allowed to dry and harden and is wrapped tightly with rattan. The darts, which are about the size of a steel knitting-needle, are made from the midribs of palmleaves, and at one end there is a small conical butt, which fits tightly into the bore of the pipe. A small nick is made in the shaft of the dart just below the point, and the end is coated with a deadly poison made from the sap of the upas-tree and another species of the genus $I p o$. When the dart strikes, the end breaks off and remains in the wound; the poison acts rapidly, first paralyzing, then killing the victim. In warfare, also, the natives poison $k r i s$ and spear, and the wound is invariably fatal.

Fighting a full-grown orang-outang with weapons so primitive is extremely hazardous work, and 
the natives avoid it except when a beast becomes a menace to the village. An orang-outang in battle is ferocious. If it is treed and afraid to come down, it goes into a paroxysm of fury. It will bite its arms, tearing the flesh away and inflicting frightful wounds. If there are two of the animals, they bite and hug each other. An orang-outang that has been struck by an arrow can follow the natives in the trees or on the ground while the poison is taking effect. The only refuge from the frenzied creature is the smoke of a fire, and, when it is sufficiently enraged, even that will not stop it. The best chance lies in keeping it so harried that it does not know whom to attack; once it decides on a particular native, the native is as good as dead. When the poison begins to work, after an animal has been wounded, the natives end the fight with knives. The possibility of an orang-outang attack is a danger that all the men must be prepared to face, and the duty of engaging in an orang-outang hunt is no less important than that of making war. It was but normal, therefore, that, as soon as I had convinced the villagers of my trustworthiness, I should have their hearty support.

After putting the men to work on the nets and cages, I selected a crew of twenty-five to accompany me while I went out to get the lay of the land. I warned the men against doing anything that might frighten the animals unnecessarily and explained that we should do no hunting for smaller game until 
we had attended to the two big orang-outangs. With the guides leading, we started into the dense jungle, and, after several hours of slow, tortuous traveling, we came to the tree where the animals lived. I could see, far up, the platform they had built.

Fortunately the orang-outangs were not there, and we were able to inspect the location at our leisure. I stationed the men at one side, telling them to wait for us, and then Omar and Munshee and I circled the tree. The surrounding jungle was as thick as any I have ever seen; the trees were so close that their branches mingled and they were woven togther with creepers, vines and rattan. It was not possible to go forward a step without cutting the way. The tree in which the orang-outangs lived was the largest in the vicinity. Nearly an hour passed before I decided upon the course we would pursue. Squatting with Omar and Munshee, I explained how we would cut away the trees, so as to leave in isolation the one in which the animals had their platform; then, how we would cut that tree and tumble them into the net.

We went back to the place where the men were waiting, and I put them to work at cutting the mass of creepers that bound the trees together. The jungle was so dense that it would have been impossible to fell the trees without first cutting the network woven between them; for it would have held the trees upright even though they were cut at the base. 
Without tearing the creepers to the ground, we cut back as far as sixty feet on all sides. I estimated that the trees beyond would be well out of swinging distance for the orangs. At the point where I planned to have the big tree drop, I had an additional thirty feet cut. Then, when the creepers were all simply hanging, we began work on the trees.

First-rate native jungle men use their parangs with astounding rapidity and accuracy. I doubt if there are any finer woodsmen in the world. Their greatest fault is that they like to stop working in order to talk. Omar, Munshee and I, knowing this weakness for conversation, circled through the jungle constantly, urging our men on. Partly as a result of this watchfulness, perhaps, I have never seen natives do a piece of work more neatly and rapidly. It was vitally important, of course, that we finish before the big fellows came swinging back home.

The trees were cut so that they remained standing. We were trying to achieve something like a flimsy structure built of cards or dominoes, which one push will send toppling. At a signal, every tree in the circle I had mapped out was to fall, those at the center, first, and the others in order, until the one in which the orang-outangs had their platform was isolated. It was a nice problem in jungle-craft to cut the trees so that they would bear the weight of animals swinging in the branches, and yet be so weak that they would all fall-and in the proper 
directions-when we started them by pulling on the ropes. I allowed myself to be guided entirely by the judgment of the natives; they appreciated my confidence and took care to see that the work was done accurately.

The hacking of the parangs and the conversation attracted hundreds of jungle animals, including many of the smaller orang-outangs. We did not molest them, and they grew bolder, until we had a large, chattering, screaming audience watching us work.

Long before the two big brutes came back to their home, we were on our way to Omar's kampong, with the first stage of the work completed. The jungle as we left it did not appear greatly different from the way it looked when we arrived. I knew that the orang-outangs would realize that some one had been there, and yet I was fairly certain that the absence of human beings would reassure them. And, too, they would have several days to accustom themselves to whatever changes they noticed.

At the kampong, I called the men together again, this time for an informal council. I told them that I had considered carefully everything they had said the day before, and that, after inspecting the location, I had come to the conclusion that we could easily capture the animals. It would be simply a matter of rapid work and of each man's thoroughly understanding his job. Drawing a circle on the 
ground and planting a stick in the middle, I explained what we were to do and how we were to do it. Then I told them how we had cut the creepers and prepared the trees.

During the next four days we avoided the location as much as possible. Crews of men, bearing bundles of dry grass and bushes, approached within five hundred feet, dropped their bundles and returned to the village. The grass and bushes were to be used for the fire I planned to build at the base of the tree, once the orang-outangs were isolated there. We took care never to go near when the big fellows were at home, and the other jungle creatures grew less and less perturbed each time we appeared.

I remained at the kampong, supervising the making of the nets and cages. The entire population helped us, and I put some of the people to work at making smaller cages and rigging snares for other animals. Finally, when the nets and cages were ready and the material for the fire gathered and in place, I began drilling the men in their parts. Thirty men were detailed to the work of pulling down the trees in the circle; ten men to clearing the space where the big tree was to fall; and ten men to handling each side of the big net. It was upon the last-named crew that the success of the attack rested, for any mistake or delay in manipulating the net would mean that the animals would escape-even probably with disastrous results. 
Omar and Munshee helped me select the men from the number of those who had previously demonstrated their courage and resourcefulness in the face of danger. I had a long pole put up near the village, and we rehearsed the capture innumerable times: the pole would fall, and the men would cast the net and secure it over the bunch of grass tied to the top to represent the orang-outangs. We repeated that performance for several days, and I always stood by with my rifle in my hands as if I were ready to put an explosive bullet into the bundle of grass, if it tried to escape.

When they had played the part so many times that there seemed to be no chance of a blunder, we had a full rehearsal. As the pole fell, this time, the other men closed in, beating with the clubs, pounding tom-toms and yelling. I wanted them to make just as much noise as possible when the orangs came down; for noise paralyzes animals with fright and makes them easier to handle.

On the eighth night at Omar's village, I called all the men together and announced that we would start next morning before daybreak. Once again I made them promise that they would not kill the beasts without my permission, and I, in turn, promised them that I would shoot if there was the least danger. Long before daybreak the village was astir. All those who were to take no part in the hunt were ordered to stay behind, and they stood silently watching us while the men shouldered the 
nets and ropes and filed into the jungle blackness.

By the time it was light, each man was at his post, waiting for me to fire my pistol as a signal. We could see the two orang-outangs sleeping on their platform.

The men who were to give the trees the final cut and send them toppling over stole forward silently. Ali was beside me, carrying my rifle; Omar and Munshee were stationed near, one at each side. I waited, scarcely daring to breathe, for them to signal that their men were ready. Ali was intently watching the orangs, to warn me if they stirred.

Omar moved first; then Munshee. I gave a quick glance around and fired my pistol. Instantly the tumult started; the men yelled and beat upon tomtoms and trees. The orang-outangs leaped up bewildered and scrambled about their platform. Through the noise I could hear the men at work with their parangs; then came the crashing of trees. The jungle seemed to fold up, and the big tree stood alone. The orangs screamed and hugged each other. Men rushed forward with the bundles of dry grass and started the fire; others came with wet leaves to make a smudge. One of the orangs started, as if to come down, and I reached for my rifle; but when the smoke struck him, he went back to the platform, screaming and tearing the tree. Then, as the smoke became more dense, the two animals climbed higher and sat on the topmost limb, arms 
and legs wrapped around each other, completely terrified.

The natives danced and yelled. Through the clouds of smoke that drifted over us, I could see their black bodies flashing, arms waving, and lips, stained crimson with betel-nut, wide open. The din was terrific. For several minutes I just stood there, unable to move.

The orang-outangs, high up in the tree, were huddled together, swaying back and forth. Omar came with the message that the space was cleared for the tree to fall; I ordered the net carried to position and sent the two headmen to place the natives at their posts.

Dense clouds of smoke rolled up from the smudges, enveloping the tree completely and hiding the orang-outangs, who perched aloft, screaming and coughing. I could get occasional glimpses of them, as they sat there, hugging each other.

The big rattan nets were in place, with the men holding them ready to cast when the tree came down. Other men, armed with sharp-pointed poles, stood behind, to pin the beasts down if the nets did not fall in the proper position. They were so excited that I spent several minutes in casually walking about, talking with them and calming them. Ali trudged a few feet behind me, carrying my express rifle.

We cleared away the litter of tree trunks and creepers from the spot where the big tree was to 
fall, so that there might be nothing underfoot to interfere with rapid work; then I gave the signal for the tom-toms. The racket began again and the crew of men detailed to cutting the tree ran through the smoke barrier, waving their parangs and shouting. I stood outside, near the net, watching the orangs and keeping the men at their stations. Omar was with me, and Munshee was with the men who were doing the cutting. We could hear the big knives hacking into the tree.

A messenger from Munshee came with the word that the tree was ready to drop. I gave a hasty glance around me, told the men to be on the alert and sent him back with instructions to let the tree fall. Once again through the din of tom-toms and shouts we could hear chopping; the tree swayed for a moment, the orang-outangs screamed with terror and the men with the nets crouched, ready to spring. Slowly the tree toppled and came down, gathering speed as it fell, exactly in the spot we had marked. When it struck, the entire jungle seemed to be in upheaval.

The orang-outangs abruptly stopped their outcry. As they hit the ground, they were paralyzed with fright. A net went sailing over them. In an instant they came to their senses and began fighting. With long, black, powerful arms they lashed at the rattan; they leaped and struggled, biting the ropes and tearing great gashes in their bodies. They screamed and chattered furiously. One of them 
reached out and grabbed a native by the throat, whipping him through the air and breaking his neck. The native struck the ground several yards away, blood pouring from his nose and mouth.

I yelled to the men to cast the second net and secure it to the trees. The orangs kept up a constant battle, lashing and heaving under the ropes that pressed them to the ground. Their arms and legs became entangled in the meshes of the nets, and they wasted their strength in wrenching and squirming, while we fastened them down. The natives, crazy with excitement, pressed in, tumbling over one another.

Our material had been put to the greatest test and would hold the animals, I knew, for they could not again equal the struggle of the first few minutes. So, because I wanted them to have room to become thoroughly tangled in the nets, I ordered the ropes slackened a trifle.

Just then, while I was standing near the nets, superintending the work of making them fast, a huge paw shot out and grabbed my ankle. I was jerked off the ground and, as I fell, my hands caught the limb of a tree. I clung to it with all my strength, feeling my fingers weaken and slip while the brute pulled. The joints at my hip and knee pained me for an instant; then my leg became numb. The men stood terrified and I could not yell at them! I felt myself growing dizzy and I simply wondered why some one did not do something. 
Then Omar grabbed a club and pounded the orang's arm; the pulling stopped, and I realized that I was being dragged away from the nets. For several minutes I was too groggy to know what was happening, but the idea that the natives might kill the orang-outangs while I was disabled made me sit up. They were standing there, looking first at me and then at the animals, wondering what to do. I told them I was all right and I began feeling my leg. It was not broken, but it had been so badly wrenched that I could not stand on it.

While I sat on the ground directing the work, the men gathered the outside meshes of the nets and ran a rope through them. Then, as the other ropes were loosened, they pulled the noose close, and the two brutes were in a sack. For the first time, I had an opportunity to examine our catch; they were the two biggest orang-outangs ever captured in Borneo.

Gradually they exhausted themselves and gave up the struggle. They peered out through the meshes, snarling at the men who came near them and sometimes shooting out a long arm with the fingers opening and closing. The natives squatted about in a circle, watching the animals and laughing.

When the men had rested, I had them build two litters of boughs-one for the dead man and the other for me. Then we strung the net on three long poles, to be carried by twelve men, and started 


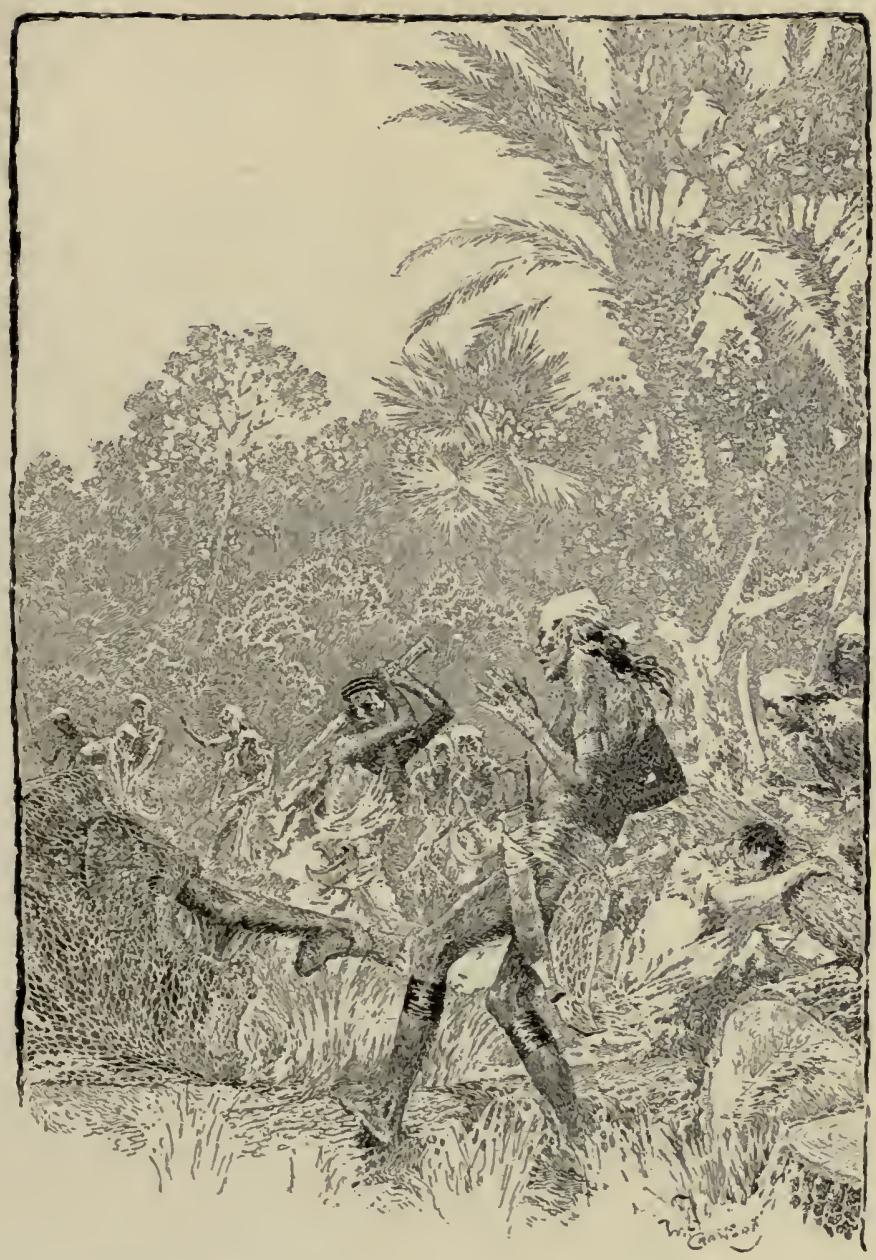

"A huge paw shot out and grabbed my ankle. I was jerked off the ground, and, as I fell, my hands caught the limb of a tree. . . The brute pulled. I felt myself growing dizzy. . . Then Omar grabbed a club and pounded the Orang's arm." 

back to the village. Messengers went on ahead to tell the people of the kampong of our success. I headed the procession; then came the orang-outangs with natives dancing around them and beating tomtoms; then the dead man. It was necessary to stop often to change the crews that were carrying the litters and animals-they weighed over five hundred pounds-and the entire population of Omar's kampong came out to meet us in the jungle before we had covered half the distance. My coolie boy, who had remained at the village, was ahead of them all. He was one of the fastest rickshaw men I have ever seen, and his old training came in handy that day. He wanted to carry me in his arms back to the village, but I told him to run back and put some water on to boil for me.

I left Omar and Munshee in charge of the orangs and had my men hurry ahead with me, for my leg was paining me intensely and I could feel the fever coming on. I had many things to do before I could afford to be sick, and I did not want to lose any time. For one thing, I realized that it would be impossible to get the animals into separate cages and that it would be necessary to build a larger cage before we could take them from the nets. It would be too dangerous to leave them in the nets overnight, for they might chew their way out.

At the village I found that my boy had laid out my medicine kit. I soaked my leg in hot water and massaged it; then we painted it with iodine and 
bandaged it tight. By the time the procession arrived, I was ready to give Omar and Munshee orders about the new cage.

While the women prepared the feast of chicken, rice and sugar-cakes, the men went into the jungle again and cut logs eight feet long and from six to eight inches in diameter. These they drove two feet into the ground, placing them not more than three inches apart, so as to form a cage eight feet long and three feet wide. Then they bound them together tightly with rattan ropes, and made and lashed down a strong roof of logs. One end of the cage was left open for the animals to enter.

Propped up on my litter, I directed the work; then I was carried while I made a careful inspection of it. When the cage was ready, the orangoutangs were brought up to the open end, the poles were drawn out and the slip-knot of the outer net was loosened. By using poles and working at a respectful distance, the men forced into the cage the single net containing the animals; then they drove the end-bars into the ground and lashed them. Finally, by working between the bars, they loosened the slip-knot of the net and left the orang-outangs free to untangle themselves.

By the time the job was finished, I was exhausted by the fever, and my leg was paining me unbearably. I thanked the men for their good work and was carried back to Omar's house. The people were disappointed that I could not take part in the 
great celebration they were preparing, and deputations arrived at the house to ask if they could do anything for me. In a hundred different ways they showed their concern for me and their kindness, and I know that they would have dispensed gladly with their merrymaking if I had intimated that the noise might keep me awake. Sleep was, of course, out of the question, but not because of the noise; my leg was puffed and swollen, and the fever was growing worse. Outside, I could hear the people celebrating. The ceremonies began with the funeral of the man that had been killed and they lasted until daybreak.

In the morning I sent for Munshee and told him that it would be necessary for me to go down the river to Sintang, where Dr. Van Erman lived. He selected four of his fastest boatmen and sent them off to the doctor with the message that I was coming. Their orders were that they might stop at Nanaoh-Pinoh to eat, but that they were not to rest until the message was delivered. Just as soon as they were out of the way, Munshee turned to preparing a boat for me; an awning made of palmleaves was put over the center and a bed arranged.

I left Omar in charge of the orang-outangs, with Ali to assist him. Ali objected to being left behind, but I explained to him that he could be of greatest service to me by staying. He was to see that the orang-outangs were fed and watered and to have the natives trap other animals for me. I instructed 
Omar to build a shed over the cage and to place a fence around it, so that none of the natives could venture too close.

When my boat was ready, all the people of the kampong were on hand to bid me good-by and wish me a speedy recovery. Munshee steered and six men paddled. Another boat followed with my supplies. I went down the river, thinking that I had never found a kinder, more hospitable people than these, who are known throughout the world as savages and head-hunters.

My fever grew worse and worse and I became delirious. I did not know until later that Munshee urged the men on, hour after hour, until we overtook the messenger boat. The last thing that I remember of the trip was that everything became a blur. The men who were paddling, the river with $\checkmark$ its green banks, Munshee, the awning over my head and the coolie boy all whirled around and grew indistinct. I was unconscious when we reached Sintang.

Two days later I awoke in Dr. Van Erman's house and was unable for some time to realize where I was and why I was there. The doctor came in and talked with me for a few minutes. He said that I would be well in two weeks and that my leg was not badly damaged. Then I drifted off to sleep again.

The next day I felt stronger, and the doctor repeated some of the tales the natives were telling 
about the capture of the orang-outangs and the death of the crocodile. The stories had improved with age, and so I told him what had actually happened.

"Mahommed Munshee has been waiting here for you to get well," said the doctor. "I think he'd like to see you-if you don't mind."

Munshee came in, beaming with delight. Taking my hand and pressing it to his forehead, he told me that only one chosen by "God and Prophet" could recover from the fever and the sickness caused by the paw of an orang-outang. All of the villagers, he said, had been making offerings to the different deities for my recovery, and the people would be happy to hear that Tûan was well again. I told him that I would return with him to Omar's kampong within two weeks, and he left, promising to come for me.

The days at Dr. Van Erman's house passed quickly and pleasantly. I found him a thoroughly fine man, as well as a fine doctor, and I enjoyed his companionship. Under his care I rapidly threw off the fever, and my leg healed so that I could get about with little difficulty. The ankle had been dislocated by the grip of the orang-outang's paw, and the tendons badly strained.

By the time Mahommed Munshee came for me, I was quite ready to go up the river. I had seen enough of the country to know that the jungles were full of animals, and I wanted to capture as many 
as possible before starting back for Singapore. Munshee said that the orang-outangs were in good health and that Omar's men, working with Ali, had made many captures. Dr. Van Erman cashed a draft for me, so that I should have silver money to distribute to the natives who had helped me, and I started up the river, promising to stop on my way down so that the doctor could see the animals.

At Munshee's request, I stopped overnight in his village. The people gave me a royal welcome and we had a fine celebration. The news of my coming went ahead of us, and Omar and Ali came down the river, meeting us two hours' distance below the kampong. They gave me an enthusiastic reception and I was touched by their affection. We rowed on up the river and, when we reached Omar's village, I found that the people had been busy for days, preparing the festivities in honor of my return.

After greeting the people, I went directly to the cage of the orang-outangs. They showed little fight, and I was encouraged to find that they were not too despondent. I did not want to risk transporting them until they had become thoroughly accustomed to captivity-or at least as much accustomed to it as is possible for orang-outangs. For homesickness grips them just as it grips human beings, and they become pitiable objects. If they refuse to eat, it is scarcely worth while to spend time and money in transporting them, for seasick- 
ness and the excitement of traveling will kill them. I had been lucky enough to find my captives eating quietly and taking life calmly.

The celebration lasted until dawn, but I excused myself early and went to bed. Omar explained to his people that I would become ill again unless I rested, and they escorted me to the house with all the ceremonious attention that they would have shown to royalty. I did not appreciate at the time quite how near I was to being a royal person in their eyes; but I found out later that Ali, during my absence, had been absolutely shameless in the tales he told about me. I habitually dined with sultans and rajas; I was an exorcist, renowned the world over; I feared no hantu (ghost) and, in addition, to all that, I was a master of hobatan (magic), who, by using his powers, could capture elephants as if they were monkeys. But, apart from Ali's stories, the people liked me because I had engineered the capture of the beasts that had been terrorizing them. And I liked them better than any other people I had met in all my travels.

Before beginning the work of capturing other animals, I turned my attention to preparing the transportation cages. These were three feet wide, three feet high and five and a half feet long-just large enough to hold the orangs, without giving them any chance to wrench at the bars. They sat clutching each other while we placed the transportation cages at each end of the big cage. Occasionally 
they snarled at us and reached out between the bars. Natives armed with sharpened poles held them back. Then, by poking and prodding, we separated them and ran bars through the center of the big cage. These operations excited the beasts so greatly that we left off work for the day. The next morning we went to the cage again and cut away the endbars so that the animals could enter their transportation cages. These gave them more room, and I stationed an extra guard over them with instructions to call me immediately if they began to tear at the bars. Ali spent practically all of his time there, talking to them and feeding them. Gradually they became accustomed to him, and, although they were far from accepting him as a friend, they did know him and realize that he was not there to hurt or annoy them. All others, except the headmen and myself, were kept away from the cages.

Food was always placed in the transportation cages, and, since the animals were deprived of each other's company, they became accustomed to spending their time in them. That, of course, was exactly what I wanted, and the prospects looked more encouraging each day.

We spent the next two weeks in trapping and snaring, and I kept the men of the kampong busy all the time, either at collecting the animals or at building cages for them. I was fortunate enough to get one proboscis monkey. It is a rare, longnosed species, difficult to capture. My standing 
orders from zoölogical gardens all over the world always included one of these creatures, but this was the only one I ever caught. We found him hopelessly tangled in a net we had put up near a watering place. He was a fine specimen, two feet high, with long arms, legs and tail. and a nose that measured two inches.

Netting animals in the way in which we caught this monkey is one of the easiest and best modes of collecting. The size of the net and of the meshes will depend entirely upon what one hopes to capture. Our nets varied from eight feet square to fifteen feet long by ten feet wide. The meshes measured from two to four inches. The net is placed at a spot where animals are sure to pass; it is suspended across the trail and held in place by light bamboo poles. Leaves and grass are scattered over it until it cannot be distinguished from the ground. When an animal steps into it, the net falls and he begins to struggle instead of quietly working his way out. Within a minute he has himself so tangled in the meshes that it is sometimes necessary to cut the net to get him out. One great advantage connected with this method of trapping is that the animal is never injured; he simply wears himself out and then, exhausted, stays in the net until some one comes along to release him. A cat animal, for example, comes running into a net; its feet catch and it goes tumbling, rolling over and over, roaring and pawing. In a few seconds it 
becomes so tangled that it cannot move an inch. Its cries bring the men who have been posted as lookouts, and they carry it back to the kampong on poles.

Contrary to the general idea, cat animals, such as tigers and leopards, are the easiest to catch in traps as well as nets. The work is as simple as baiting a rat-trap and it requires little sagacity. A box-trap with a spring-door will make a catch time after time, with no more trouble than transferring the animal to a transportation cage and rebaiting the trap with a chicken or a small goat. It is wise to allow a fairly long runway between door and bait so that the captive will not be injured when the door springs shut. After recovering from the surprise of finding itself trapped, the animal eats the bait, which supplies it with food until the natives come along on their regular tours of inspection. It is just routine work, involving but little excitement.

Among the animals we captured while working from Omar's kampong were three gibbons, or wahwahs. These are also known as flying gibbons, because they make such long leaps from tree to tree. They are a tailless breed of monkey, rather rare and extremely difficult to catch. Once captured, they become affectionate pets and they command a good price for that reason. They have soft, downy, light brown, silver-gray or yellow hair, black faces and large, round, expressive eyes.

The work of trapping and snaring went along 
steadily during the ten days I spent with Omar. By the time the orang-outangs were ready to travel, we had three gibbons, four baby orang-outangs, one proboscis-monkey, ten black monkeys, eighteen long-tailed monkeys, twenty-two pig-tailed monkeys, three pythons, which averaged eight feet in length, two sambur deer, one sun-bear, three wildcats, four civet-cats, four porcupines, one ant-eater and two armadillos.

We slipped the bars over the open ends of the cages in which the big fellows were to travel, and lashed them securely with rattan ropes. Since the boats at the kampong were too small, I had two large rafts made of bamboo and I placed all the cages on them.

When everything was ready, we boarded the boats and rafts and started down the river. The people lined the banks, shouting and wishing us a safe journey; others followed us in boats. At each village, the natives swarmed out to see the animals and wish us luck. I can still hear them calling: "Tûan, bîla bâlik? Salâm-at jalân! (Sir, when will you come back? Safe journey!)"

We stopped at Mahommed Munshee's village, and then at Sintang. I found that Dr. Van Erman had gone down to Pontianak. Another swarm of natives met us when we arrived there, and I had to station my men around the rafts to keep them from coming aboard.

Leaving Ali in charge of the animals, I went 
ashore and found that a steamer was sailing for Singapore the next morning. I made arrangements for shipping, and then went to the Resident's house to pay my respects. Dr. Van Erman was there and, after luncheon, I took the Resident and the doctor out to see my catch. The Resident was profuse in his congratulations and he confirmed my belief that the orang-outangs were the largest ever captured in Borneo.

Omar and Munshee assisted in the work of loading the crates on the steamer, because they felt that their obligation to me did not end until we had the animals clear of Borneo. I felt, of course, that I was under obligation to them for all the fine work they and their people had done for me, and I wanted them to accept some money for their services. They refused at first but finally they gave in. From their point of view, they had made sufficient profit, merely in prestige, both with their own people and with the Resident. I made them my agents in their districts and took them with me to the offices of the steamship company while I arranged to have any animals they brought to Pontianak shipped to me at Singapore. When we sailed the next day, they were in their boats alongside, waving and yelling.

There was great excitement in Singapore when the story of the orang-outangs got about. Hordes of people came to see them unloaded. I called upon the police to keep the crowd back, for I was afraid 
the excitement might be too much for the beasts.

At my animal house, I put them in a quiet spot and left Ali in charge with strict orders against letting too many people come to see them. Then I went to the cable office and sent to the Antwerp Zoölogical Gardens news of the capture.

There was no question in my mind as to what the answer to my cablegram would be, and, before it arrived, I made all the arrangements for shipping. Antwerp offered $\$ 10,000$ each for the animals delivered. I knew that I could get offers of $\$ 25,000$ or more in the United States, but that the orangs would not be able to stand the voyage. I sent another message to Antwerp, saying that I was sailing and requesting that arrangements be made for shipping by rail from Marseilles.

A few days later, the cages were swung aboard and we started eastward. Ali accompanied me to care for the animals.

From the moment the steamer headed out to sea, the orang-outangs began to fail. They became deathly seasick, especially the female, and refused food. Ali and I were with them constantly, tempting their appetites with choice bits of food and doing everything possible to make them comfortable. The male grew better but the female lost strength rapidly. Finally she slumped down to the floor of the cage, unable to sit up; she paid no attention to us when we reached into the cage and touched her.

One morning she curled up on the floor, buried 
her face in her arms and died. Through her death I lost a great deal of money, but I could not help feeling relieved. She had been so abjectly miserable and she had seemed so human in her suffering! I have often wondered if the male had any idea that she was dead. He ceased to improve in health and he became morose. Many days of anxiety followed; every minute I expected the message that the poor fellow was dying.

The ship's carpenter built a vat, and we "pickled" the body of the female in salt water. I knew that some natural history museum would be glad to have such a specimen for mounting. We steamed into the harbor at Marseilles with the male still alive, and I thought that there was an even chance of getting him to Antwerp if the people there had followed my instructions and arranged transportation. An agent met me at the dock. Everything was prepared for us, and we lost no time in getting the beast to the train.

When we reached Antwerp, I felt like standing on the platform and whooping. My job was finished.

The men from the Gardens took charge and rushed the orang-outang out to the cage that had been built to receive him. We ran the transportation cage up to the door and cut away the bars. The orang-outang came out slowly, like a tired and sick old man. He was not interested in his new surroundings and he pushed away the food that we 
put before him. Veterinarians could do nothing for him. Ten days later he died.

Ali and I remained in Antwerp for several weeks. It was Ali's first trip to Europe, and not a very enjoyable one. He was bewildered and puzzled; he could not understand such a country. Only once did he venture out of the hotel without me, and then he did not go out of sight. He slept in my room on the floor-he would have nothing to do with a bed-and he would touch no food that was not vouched for by me.

When we boarded the boat that was to take us back to the Far East, Ali's face brightened. He had had a wonderful experience, but he said: "Oh, tûan, I am happy to go home: I would not live here." 


\section{VI}

\section{"KILLING A MAN-EATER"}

$\mathrm{B}^{\mathrm{EFORE}}$ describing my experience with a maneating tiger, I want to tell something of their habits and the usual methods of hunting them.

There are three classes of tiger, the game killer, the cattle killer and the man-eater.

The game killer confines himself to heavy jungle amongst the hills, where he keeps to the feeding-grounds and resorts of game; he is a great killer of deer and wild pigs; he shuns the haunts of man and wanders in the jungle at all hours.

They are lighter and more active than the cattle killer. Doubtless the reason is that they have to travel farther for their food.

The terror inspired throughout a district by a man-eating tiger is extreme and the natives are only safe in numbers. The rapidity and certainty of its movements form the chief element of the terror it causes; it is generally an old tiger or tigress, or one that has been wounded or otherwise hurt, and has been unable to procure its food in its usual way.

Cattle-killing tigers frequent jungle close to villages and seize a victim amongst cattle where they graze, or pick up a stray animal about the villages at night. 
The largest tigers are found amongst the habitual cattle killers. When a tiger becomes old and fat he usually settles down in some locality where beef and water are plentiful, and here he lives on amicable terms with the villages, killing a cow or bullock about once in four or five days.

A full grown, large tiger would have no chance in a fair fight with a bull-bison; the latter's brawny throat, with its hide one and a half inches thick, would afford him a difficult hold, even could he attain it, and no wrench could dislocate the bison's powerful neck, while the tiger would be crushed out of all recognition if once caught between the ground and the bison's massive forehead or forelegs.

I have never witnessed a tiger actually seize its prey, but it has been described to me by natives who have seen them many times while tending cattle. The general method is for the tiger to slink up under cover of bushes or long grass ahead of the cattle and to make a rush at the first cow or bullock that comes within five or six yards. The tiger does not "spring" upon his prey in the manner usually represented, but clutching the bullock's forequarters with his paws, one being generally over the shoulder, he seizes the throat in his jaws from underneath and turns it upwards and over, sometimes, springing to the far side in doing so to throw the bullock over and give the wrench which dislocates its neck.

The popular belief that a tiger can kill his prey 
by a stroke is erroneous. I have never seen anything to support this belief nor is it held by natives. I have seen several cattle severely lacerated which had escaped from tigers, where had a heavy blow accompanied the strokes of the paws, bones must have been broken.

There is no foundation for the belief in tigers sucking the blood of their victims; the jugular vein is seldom if ever injured; it is by the fracturing of the vertibræ, not by blood-letting, that the tiger's prey is deprived of life. In eating, the tiger invariably commences at the hindquarters and the exact spot where the first mouthful will be taken can be told with certainty.

The flesh of one or both thighs, and sometimes the flanks, or about fifty or sixty pounds of meat is eaten the first night.

Tigers seldom lie up far from their kill if the cover be thick and quiet; they eat whenever inclined either by day or night till the carcass is finished; this is usually on the third day; but of course, this depends upon the size of the animal killed. After or during a meal the tiger drinks largely, often walking belly deep into the water.

Tigers' power of enduring hunger and thirst is very great. Once we surrounded with nets a tiger, tigress and a leopard. We shot the leopard the first day, but the enclosed thicket was so dense that we could not get the tigers to show, but on the fifth day we wounded them both. After this, as nothing 
would make them break cover, I sent for elephants and killed them still full of vigor on the tenth day. The circle in which they were enclosed was about seventy yards in diameter, and the heat of the fires kept up night and day was considerable, yet they existed without a drop of water for ten days, suffering from wounds half the time. A tiger can go much longer than this without serious inconvenience. One of the most powerful elements in the tiger's attack is his voice. If the attack be commenced very near, the startling, coughing roar is almost paralyzing to the coolest, but if the tiger has to come on from any distance, he rarely does more than grunt, and the hunter's attention is concentrated on the beast itself, so the demonstration passes unnoticed.

The power of the tiger's voice at close quarters may be understood by anyone who has had an opportunity of seeing a newly caged tiger; it is almost impossible to watch the charge against the bars without flinching, if standing within a yard or so of them, but if seen at twenty yards distance it is nothing.

The tigress does not breed oftener than once in two years. They do not breed at any fixed season. Cubs have been taken in March, May and October.

A tigress feeds her cubs when very young with half-digested flesh which she disgorges on her return from hunting or kill. Carrying meat to any distance would be an unnatural proceeding, and the 
half-digested flesh is probably better adapted to the requirements of young cubs.

When only six weeks old the cubs move from place to place with their mother, but are left at home while she hunts, though she leads them to feast if near when she kills.

Watching for the return from a kill, or at a pool where they are known to drink, is a method of hunting chiefly practiced by natives. Poison pitfalls and traps are generally brought into play when dealing with a man-eater. There is perhaps no method of shooting tigers so seldom successful as watching for their return to feed on animals they have killed. For my part, I confess to a great liking for the silent and solitary watch, which kind of shooting requires the utmost vigilance and patience.

In a shady, green-screened platform in some fine tree, watching at the cool of evening, when jungle sounds alone break the stillness and birds and animals seldom seen at other times steal forth and can be watched at leisure, an intense excitement is kept alive by the possibility of the tiger's appearance at any moment. Those without experience at this game do well to pause, but one who knows the beast he has to deal with may kill many dangerous animals on foot without accident or even serious adventure. Almost every accident that occurs is directly traceable to ignorance or carelessness; the hunter is a tyro or over-venturesome, or due precautions are not observed when following a wounded beast 
on foot and moving about where he does not think the animal can possibly be, he is seized.

Tiger shooting on foot can never, of course, be safe sport; risks must be run, but if properly conducted, dangerous game shooting on foot is not the mad amusement usually supposed.

It makes all the difference in the world whether the animal to be attacked is wounded or not, and whether any tiger should be attacked on foot or left alone depends greatly on the nature of the jungle in which he is found.

In the grass plains and thick undergrowth in parts of the Malay Peninsula I have seen tigers that could only be shot at from the elevation of an elephant's back. None but the utterly ignorant would think of following a wounded tiger in the long grass or close cover where it has every advantage, and the hunter may be seized before he has time to use his rifle. In such cover the tiger rarely makes any demonstration, seeking only to avoid observation, but when almost stumbled upon he attacks like lightning.

Under no temptation should a hunter's last shot be fired at a retreating beast.

The really best time for tiger hunting in the Malay Peninsula is in the height of the hot season, July and August, when the water supply is at its lowest ebb. The tigers being very impatient of thirst, seek the lowest valley where much of the 
game he preys upon has gathered and where the village cattle are regularly watered.

It is quite useless to devote much time in hunting the hill or game killing tiger that preys upon game alone; they are so scattered over a large tract of jungle and so active and wary that it is only by accident that they are ever brought to bay.

The average size of a full-grown tiger is from eight and a half to nine feet from nose to tip of tail and weight from two hundred and seventy-five to three hundred and twenty-five pounds.

One day an old friend, Tungku S'leman, a petty rajah from Kelantan, then under the Siamese Protectorate but now under the British, called on me and invited me to go back with him to his district to trap or kill tigers, and he assured me I would be able to get some fine tiger cubs. I was in fact very anxious to secure a few good specimens of young tigers, but as his district was far inland, near the boundary line of a small state called "Rawang," I did not think it worth my while to go, for it would involve a lot of time, and knowing the Malays and their ways so well, it might mean that I would have to beat about the country on a wild goose chase. A Malay will always exaggerate, no matter on what subject, and, as stated elsewhere in my articles, they finally believe what they are telling. They will never do today what can be put off until tomorrow - "Nou-tee Bess-so" (wait tomorrow) is one of the principal words in their vocabulary. 
As the Tung-ku's district was difficult to reach, the Kelantan river branching miles from the nearest point, and elephants being the only means of travel, I told him that if I decided to go back with him he would have to furnish the elephants and all the men I might need. I also pointed out to him the difficulty in transporting animals and cages to the coast, and that the cost in time to me would probably be greater than the trip and animals were worth. It was my policy not to show any interest.

I could see that the Tungku was anxious to have me return with him to his district, as it was tiger infested, and his people were leaving on that account. He agreed to do everything in his power as to men, elephants and transportation to the coast. I told him I was very busy but that I would think it over, and to come back in a few days when I would give him a definite answer.

As nearly all my animals had been shipped from my house in Orchard Road, I decided to take the trip with Tungku S'leman and go in for not only tigers but whatever it was possible to get. I was keen on securing a good specimen of rhinoceros, and tapir, so made my preparations for a lengthy stay in his district, and for getting whatever animals I could, large or small. When on the following day the Tungku came to see me and I told him I would go back with him, he seemed a happy man. I advised him to send his chief follower on ahead so that he could have the elephants meet 
us at the end of our trip down the Kelantan river, to take us inland, as that would save a lot of time and unnecessary waiting for them to come down for us. He assured me the elephants were there as they would remain until he returned. So the following week we started up the coast in a small vessel, and arriving at Koto Bharn, we went up by boat to the capital, Kelantan, and the next day after paying my respects to the Sultan, we started up the Kelantan river to where the river turned further south. Here at a kampong we found the four elephants of Tungku S'leman. We stopped four days at this kampong, getting everything packed that would not be used or wanted until we reached the Tungku's village, which meant a four days' journey through jungle.

Taking six men, including the headman, I started on a tour of inspection of that district for the best location to set up our traps, dig pits, and spread nets for smaller game, as the headman informed me that deer, wild pigs and tapir were numerous, but very shy. On our return to the kampong, I had a trap made and set up for the catching of tigers and leopards, and explained how the nets were to be made of rattan, both large and small mesh, and how to set them amongst the trees. I was particular to impress upon the headman that he was to remove all signs of the jungle being disturbed and if possible have a goat tied to the windward while setting up the large trap. 
I did the same at the two other kampongs before we reached Tungku S'lamen's village, where I was received with interest by the natives, as I was one of the very few white people they had ever seen, and as the runners had hurried on ahead as we were getting close to his village, they were all out to see Mân Gâgah (Sir Elephant). After resting for a few days and hearing whatever news there was regarding the man-eater that was terrorizing the district, I thought it best to try and round him up by elephants.

As they are cowardly, as well as cunning, they are most difficult to stalk, and as their movements are so uncertain it is very difficult to locate them, it was essential that the men who were to work with me could be depended upon at the right moment. I assured them that in numbers they were safe from the tiger, and that by showing a bold front the tiger would be more afraid of them than they of it. The last time it had been reported had been about ten days before, and nothing could be done for the time being, so I started the men making traps, snares and nets. These I intended to set up within a certain area, while with others I started out on a tour of inspection with the elephants to visit all the water holes and drinking pools in the surrounding district. There I intended to have pits dug and to mark the best places for setting the nets; the traps I intended to set up later, depending more on the nets, as I had already had traps set up in the kampongs 
on our way to the Tungku's village. I spent a whole week in working out different areas for snaring by nets.

I had nets made of twisted rattan in sizes of twenty by fifteen feet with meshes six inches, other nets ten by eight and five by five feet with meshes according to what the net was best adapted for.

The older men who could not follow the hunt, I had put to work making transporting or rough string cages and crates, for monkeys as well as tigers.

My plan was to work each section or area and catch by either net or pit whatever we could. Everything was in readiness to start at daybreak the following morning, when a native came running into the kampong, crying as he ran, "Re-mow, Sa-tan" (Devil Tiger). The man was about to collapse with fright and exhaustion from running. I calmed him so he could tell his story, which was that while he, his wife and daughter were gathering some faggots not one hundred yards from his hut, the tiger suddenly sprang from the thicket and striking his daughter down, carried her off in the jungle. After leaving his wife in the hut, he ran to the Tungku's kampong to inform the Tungku what had happened.

As it was too late in the afternoon to do anything I told Tungku S'lamen to send out the alarm for all the available men; the alarm is sounded by the striking of a hollow log, which can be heard for. 
miles in the stillness of the jungle, and all natives hearing the booming sound know its meaning. I advised Tungku to send five or six men back with the messenger and for them to stay with him until we came the next morning. The hunt was on, and all preparations were made at once for our early start, as the men began to flock in from the outlying kampong. They were to stay at the Tungku's kampong that night to be ready to start at daybreak after eating their breakfast. There was intense excitement throughout the whole night, very little sleep for anyone, for, as I told the men, they would not return until we had killed the tiger. A few of the natives, especially the headmen, had flintlock, muzzle-loading rifles. To these I handed out extra powder and slugs; they were really good marksmen and men who could be depended on at the right moment.

We started at daybreak. The men having eaten, everyone was anxious and eager to be off, now that the hunt was to be conducted not alone by a white man, but in numbers. There were fifty natives; the Tungku and two of his headmen with their flintlock rifles rode on the first elephant, while Ali and myself followed behind on the second, the third with stores bringing up the rear, for I had no idea when we would get back. Although the Tungku assured me the elephants were well broken, I did not place any reliance on them. Riding on an elephant and jogging along peacefully is one thing, 
and tiger hunting on the back of one is quite another. As I have mentioned elsewhere, they are excessively timid both in their wild and domestic state, and to become a well-trained, tiger-hunting elephant, one so broken must have plenty of courage and experience. It is simply madness to attempt to use an elephant that has never been broken and tried out, as they will always bolt. Then again, if one never had a gun fired from its back, the effect is rather startling to his riders. It is a terrible thing to be bolted with while on an elephant's back in the jungle. I intended to take no chances while mounted as far as shooting was concerned, depending on cornering the tiger, if possible, and if the ground were favorable, start on foot.

Besides my 50-I Io express, I had a Holland double-barrel 450 and a Fox No. I2 smooth bore shotgun. Ali had his spears, but was to use either the express or double-barrel Holland if we came up with the tiger. The other men carrying spears, parangs and tom-toms made up the party. Arriving at the place where the girl had been seized, two men who were experienced trackers took up the trail, which was quite fresh and plain and could be easily followed. Presently we came upon the remains of the poor victim. Very little was left-only the head and upper part of her body. We stopped only long enough to bury the remains. The tracks were not over an hour old, and as the jungle was sparse, it would give no cover 
to the tiger. After crossing a small stream, his track led toward a rocky hill less than two miles distant, coming suddenly into a clearing with tall grass.

I shouted to the men to spread out, keep quiet, and move slowly within a few feet of each other. As the grass was still heavy with dew, we could see where the tiger had passed through to the right into the thicker jungle. We had perhaps traveled about one hour, the tracks becoming difficult to follow on account of heavy undergrowth, when we were startled by the screaming and chattering of monkeys. We knew then the tiger was not far ahead, and at the same time the elephant that the Tungku was on, spreading his ears and raising his trunk, uttered a shrill, brassy trumpet, expressing his fear. I called to the Tungku to take the elephant back, as he would be worse than useless. He was quickly turned about and driven behind, the Tungku coming up with me, the two headmen joining the men on foot. The elephant I was on showed no sign of uneasiness; the mahout or driver spoke sharply to him, calling back to me that he could handle him as that was not the first time he had been used in smelling tiger. Still I was loath to risk firing a gun from his back.

We followed the trail of the chattering monkeys, when suddenly they ceased, as we came to a very heavy patch with thick undergrowth, excellent cover for the tiger, into which he had evidently 
gone. The patch itself was not more than seventy yards in diameter. I called to the men to stretch out and surround the place, and make as much noise as possible, keeping close together.

As soon as the patch was surrounded, I told the Tungku to send the two elephants, the one he had been on and the other one carrying stores, back to his kampong for more men, and the men as they came on were to cut and load up the elephants with all the dry wood they could; also each man was to carry some wood and as many of the long nets as had been made. These I intended to spread out at the back and as much around the sides as possible, making doubly sure he should not escape. I told the Tungku we would not leave the spot until the tiger had been killed. I had a platform built with "kaj-ongs" forming the roof. This was very soon finished, and late in the afternoon the elephants returned with more foodstuffs, wood and forty men. Each man had gathered a good bundle of dried wood, which wood I had passed around, as I intended to form a circle of fire and keep the tiger within the circle. I then had the fires started and they were kept up the whole night, but in the morning the fires that were in front of the platform were allowed to die out, and after the men had taken turns eating, I ordered them to close in about twenty-five feet, throwing the fire before them. In this way I kept narrowing the circle every few hours while we on the platform kept a keen lookout. 
On the second day one of the headmen on the left side of the circle fired a shot at what he said was the tiger. Instantly there was a great commotion and the men started shouting and making a great noise. We were keenly on the alert, as the platform faced the only spot of the circle that was open and free from fire, and hoped the tiger would break cover. Suddenly Ali, touching me, quietly said, as he raised his gun to his shoulder, "Tuemblock-on-po-ko" (behind the tree). Telling him to cover the left side, I covered the right side of the tree the tiger was crouching behind, and told Ali to shoot as close to the tree as he could without hitting it. He fired, and almost instantly I let go at a streak of yellow and black; it disappeared at once. The yelling by this time was enough to drown the grunt or roar of the tiger; there was no way at the time to know if we had succeeded in hitting it, so completing the fire circle in front of the platform, we lay down to sleep as best we could. What little wind there was, was in our direction, and kept us pretty free from being eaten alive by mosquitoes.

On the morning of the fourth day the tiger had not broken cover and as the circle had now narrowed to about fifty yards, the heat was intense, for the fires were kept going day and night. Still the tiger would not break cover. I was determined to go into the circle then with the elephant, as the nets 
were well put up at the back, outside of the fire, and that allowed more men to strengthen the sides. I was taking no chances of escape. I had two headmen get up on the elephant I had come on, and told the driver to back a short distance, as I wanted the headmen to shoot off their guns from the elephant's back, in order to watch the effect on the elephant. I told them to each fire his gun off on opposite sides but not at the same instant. Well, he never moved, and when those muzzle-loading flintlocks go off they certainly kick and make a startling noise. After that test I was satisfied to take the chance and told the Tungku that Ali and myself were going in after the tiger, and that he and his two headmen must keep a sharp lookout from the platform and have their guns trained on the opening. The mahout was a plucky fellow and felt very proud, assuring me he could handle his elephant.

I passed the word for all the men to be on the lookout and allow the fire on the right side to die out, to keep together, and those of the headmen who had guns should shoot if the tiger tried to break through. As soon as the fires had died down, I told the driver to go ahead and keep to the right side. When on an elephant in fair ground, the object should be to get the tiger to charge instead of letting him sneak away, for the hunt is then ended in a short and exciting encounter, but if once let away it may be hours before he is found again, if he ever is at all. 
Coming opposite the tree where we had shot at the tiger, and under a patch of heavy undergrowth, against a large boulder, we both saw it. Seeing the elephant it gave a coughing roar, and as it did I let go, catching it fair in the eye. Ali had his spear poised ready to throw, but the man-eater. slumped down and to make sure I put another explosive bullet in its side as it lay. I called to the Tungku we had got it. I will not try, for I could not adequately describe the scene which followed when the men knew their foe had been killed; shouting, yelling, dancing, they went wild. Runners started off at once racing back to the kampong to tell the news and have the women make ready a feast. The return to the kampong was like a royal procession. The Tungku and I on the elephant led the way, the men carrying the dead tiger, singing and laughing, calling the dead animal all manner of names. There was great feasting that night; it was made hideous with the singing and beating of tom-toms, and, although dead tired from lack of rest, sleep was impossible. In the morning the Tungku did a most astonishing thing; nothing of the kind had ever been known to the oldest subject; he set free five of his debt slaves.

On examination I found that the first time we fired at her, while behind the trees, as she leapt back from the shot Ali had fired, I had caught her in the flank, smashing the hind leg, and with all her suf- 
fering, thirst and heat, she never betrayed her cover or uttered a sound.

She measured eight and three-quarters feet from tip of nose to tip of tail and weighed about two hundred and ninety pounds. She was in milk, but though we searched, we never found her cubs. 


\section{VII}

\section{UP A TREE IN THE JUNGLE}

$\mathrm{F}^{\mathrm{OR}}$ fully a week after the killing of the maneating tiger, I devoted all my time seeing to the making of rough transportation cages, crates of all sizes, and small nets. One morning I told the Tung$\mathrm{ku}$ of a plan I had to get some large nets made in a hurry. "Te-dor, bully tûan" (Cannot be done, sir), said he, shaking his head. I then explained to him how I intended to work it. Clapping his hands to his sides he went into a fit of laughter, and was as pleased as a child, saying: "By tûan by (Good, sir, good)." I have stated before that getting work out of a Malay was an art that can only be attained by close intercourse and complete confidence on the part of the native and by making work seem play or a game. To stage the affair in the best light I had the Tungku give orders for a general assembly of the men of the kampong, saying that the Tûan had a game he wanted the men to enter into, and when they were all assembled, I told them I was going to offer prizes to the men picked out and worked as crews, that made the best and most nets in four days,one day for the cutting and washing the rattan, one 
day for the splitting and twisting the rattan into rope, and two days for net-making, the net-making to start on the third day at six o'clock in the morning until four o'clock in the afternoon and no work to be done on the nets until the next morning, when they started again at six o'clock and worked until four. The nets were to be made ten by eight with six-inch mesh, there would be four men to a crew, and three crews would go in for the prizes. Those who wanted to enter were to step forward and the Tungku would pick them out-no old men or boys. They were to start the next morning, the prizes were five dollars (Mexican) to each man of the crew that made the best and most nets, three dollars each to the next crew and two dollars each to the last. As soon as the Tungku had picked them out, each crew should choose the space they wanted to work in and set their poles and stakes for the twisting of the rattan and the making of the nets. This I told them to do as it saved them a lot of time, trouble and confusion, for then each crew would know the space it was to work in so as not to interfere and get in one another's way. The race was not to begin until the next morning at six o'clock, when they were to line up at the Tungku's house and at the word "go" start for the jungle and cut rattan.

Believe me, I started something! If there is one thing a Malay loves, it is a game or race of any kind, pitting themselves against one another; any- 
thing that has a flavor of sport that can be gambled on.

Every man was eager, and the Tungku, looking them over, picked out the men, and as each man was chosen, the men, women and children howled with delight, clapping hands, passing all manner of jokes and banter. When the men were picked out the Tungku formed them in crews; they were a pretty proud lot. Again warning them that they could not start making the nets until the second day, and that after they started in the morning to cut the rattan, if they were caught taking help from any of their friends, they would be thrown out of the race, he told them to get busy and lay out their poles and stakes. The Tungku shaking his head and laughing, said: "Tûan bow-gar poro-day seaopper pe-care, e-to ( $\mathrm{Sir}$, you are very clever, who would think of that)."

In the meantime the men and their friends got to work staking out and putting up cross-sections and poles for the twisting of rattan and the making of the nets. Everyone in the kampong was laughing and talking over it. It was going to be great sport and plenty of fun; each had their favorites and were already making wagers on them. This was not work! This was play, sport, a game, rivalry, having an audience, for the whole kampong and those from the outlying districts would be there; men, women and children cheering and edging them on, not alone for the prizes but the prestige it would 
give to be known as the best and fastest net-makers in the whole of Kelantan. The tiger hunt was off, and the net-making and round-up was on.

At daybreak the following morning, the whole kampong gathered at the Tungku's, and, after eating the breakfast of rice and dried fish, started off for the jungle to cut, collect and wash the rattan.

One who has never seen rattan in its natural state would be quite deceived by its appearance; it is not the smooth, shining, pointed cane one sees in the market; it grows as a vine, sometimes one hundred feet and over, up and down trees or along the ground, twisting in and out; it is covered by an outer shell or skin, and at each joint a circle of thorns an inch in length. The outer skin and thorns are scraped away, washed and cut in lengths of sixteen feet, one hundred lengths to a bundle, and the rattan is ready for the market. They grow in various thickness. The Malacca cane is the thickest grown.

Everybody went down to the stream where they would strip the thorns and peel off the outer skin, wash, split and cut in lengths; the crews kept cuting like mad. I do not believe there ever was so much rattan cut, stripped, washed and cut in lengths in the state of Kelantan, or in any other state, in one day as those twelve men did.

On the morning of the third day, the whole district was in holiday attire and all on edge to see and encourage their friends to be the first. The rat- 
$\tan$ was all laid out in two piles in cut lengths of twelve and ten feet and seventy-two pegs or bamboo stakes were driven into the ground. I myself had measured off the ground and stakes for length and width of nets. Twenty each, stakes for top and bottom, and sixteen stakes each for width.

The first day was pretty nearly a tie, although one crew had started on another net and had got one-quarter of it finished when a halt was called for the day. Nine nets on the following day, the crew that had one-quarter of a net finished the day before finishing four nets by four o'clock; the other two were practically tied, and as such I gave them credit; they had three and a half nets finished, and each of the crew received second prize money, three dollars each. There was great satisfaction, although the first crew with their five dollars each were strutting around and talking big. After finishing the half-made nets, I had twenty-one ten by eight rattan nets. Great work in four days; had I gone any other way about getting them, it would have taken twice as long. Even with the money prizes, they cost me on an average of only two dollars (Mexican) or one dollar each.

The third day after the net-making contest, taking fifteen men and loading their nets, large and small, on an elephant, we started off for a half day's journey from the kampong to set up the nets on the ground and in the trees, also to dig pits at the waterholes. We had been moving on slowly, the first 
elephant carrying the nets, breaking a trail for about three hours, when we heard the screaming and chattering of monkeys. The natives first thought the cry was "re-mow" (tiger); the men on the first elephant halted just at reaching a break in the jungle; they called back, all excited: "Tûan, Bar-be. Ari-men kombing, be-prong (Sir, a fight between a pig and a leopard)." By the time I arrived alongside the other elephant at the clearing both elephants were becoming restive, but were being calmed down by their drivers.

I came upon a sight I shall never forget, a fullgrown leopard and a Baba-rusa (wild boar) in a deadly combat. I was fascinated by the sight; no noise would have disturbed them, for what with the snarling, screaming, grunting of the two, and the screaming of the monkeys, it was difficult for me to even make the men I was talking to hear. The fight must have been going on for some time before we got there. The pig's jaws dripped with blood and foam, his beady red eyes following each move of the leopard, his flanks and back covered with blood from the clawing and biting it had suffered, but still strong, nimble and full of fight; the leopard's side and neck gashed open and blood streaming from the wounds. One can hardly credit the quickness of a wild boar; they are lightning fast on their feet; their big head and thick hide are a match for any tiger in a fair fight, let alone a leopard, and although a leopard is very quick, the boar with its 
wicked tusks matched him in all his moves and springs. It made no difference which way the leopard would spring, it was always met by a ripping of the tusks. It was an ideal place for an encounter of this kind; a clear, open space, neither having an advantage, the ground baked hard. It gave a firm foothold to the boar as it allowed it to turn and meet the rushes and springs of the leopard, and as the leopard would spring the boar would dart forward, throwing up its head at the same time, the tusks ripping whatever they came in contact with. The object of the leopard was to get a firm hold on the back of the boar, while the boar, unmindful of biting and clawing, was bent on getting the leopard down and disemboweling him. The men became as excited as the monkeys in the trees, and it was difficult to distinguish which were making the more noise or were the more excited. I am positive we looked upon the fight ten minutes, and I cannot judge how long they were at it before we came upon them; they were both becoming weaker from the loss of blood.

As we watched them with bated breath, the leopard kept circling around, crouching for a spring, while the boar, never taking its small red eyes from the leopard, with head lowered, was watching and ready to meet the next move. Almost too quick for the eye to follow, the leopard sprang at the boar like lightning, the boar jumped forward and aside and, in a flash, turned and as the leopard 
struck the ground, before it could recover, was upon it, striking it with its head and throwing it on its side. Standing on its adversary, with its front feet holding it down and unmindful of the snarling, biting and clawing, with a squealing grunt, the boar lowered his head and with one ripping thrust disemboweled the leopard.

It was done quicker than the eye could follow. The leopard lay where it was; it attempted to rise, but the boar, jumping and stamping upon it, it fell back, gave one or two spasmodic efforts to rise and turned over dead. The boar still standing over it, squealing, its head rolling from side to side, its hind feet sagged and, giving a squealing grunt, fell over the leopard, dead. It was truly a battle royal. I was thrilled. I could not move. It was the most thrilling sight I think I ever witnessed. My admiration for the boar was great; had he not died, and had been able to move off, I would have made no attempt to either stop or kill him. It was a magnificent fight, with the boar on his feet last.

We buried the dead fighters and went on our way. Coming to a small stream, I decided to make camp. We built platforms in trees for sleeping and as a cache for stores, cutting down the surrounding trees and leaving a small clearing. The next day I had the men cut saplings and rattan to make rough transportation cages. I wanted everything handy so a cage could be made in a few moments. The natives could not at first under- 
stand why I went to all the trouble of having all the wood ready for cages and nothing to put in them. Their idea was to get the animals first and then cage them. I pointed out that an animal in a net was sure to injure itself in its struggle to escape and the sooner it was in a cage and free from the nets, the safer it. would be, for if they were injured in any way, they were useless. We stayed four days at this camp, arranging the nets and digging a few pits after caching stores in the trees. Before starting on the first drive I explained to the Tungku what I considered the most difficult problem of the expedition, namely a clear road to the river and to the coast, as all cages would have to be drawn to the river on runners or sleds, and the jungle paths would have to be cleared of fallen trees and undergrowth. I told him he had better send four or five men to clear and widen the path to the next kampong and the headman there to do the same on to the next, and so on to the river, the headman at the river to gather bamboo and logs for making of rafts. For the drive itself and the work pertaining to it, fifty men would answer. We would be away from the kampong about one week and at the farthest one half day's journey. Should occasion arise, I would send back for bullocks to bring in the cages. Everything being arranged to my satisfaction as to the transportation, we started off the next morning and arrived at the clearing where the leopard and boar had battled, and started 
the drive at that point. The Tungku and I rode on, the elephant in the center, twenty-five men on each side and an elephant at each end, headmen with their muzzle loaders on the elephants.

At the striking of a tom-tom we all started to move toward the camp. The men were told to make as much noise as they wished and believe me it was a noisy crowd. They went at it heart and soul, not only on account of the incentive of clearing out of their district a lot of destructive animals, but the killing of the man-eating tiger and the netmaking contest, the way I had gone about things in general had inspired them all with the utmost confidence. They believed that no possible harm could come to them while with me, and my slightest wish was carried out. The drive itself is not dangerous as you are fairly safe in numbers.

With the men shouting, and cutting the undergrowth, and the two elephants at each end breaking through, there was enough noise to startle and drive any animal before it. Our work in extracting whatever we caught and the putting together of cages, would not allow those animals caught in nets much chance to bite through or injure themselves as we could handle the most violent ones first.

In handling and taking from the nets the smaller animals a thick bamboo was used hollowed throughout, about five or six feet long, with a length of stout rattan, the end doubled together and run through the bamboo, leaving a loop at one end 
which could be slipped over the head of the animal through the mesh, and drawn taut against the end of the bamboo and held by two natives. Although they would wiggle and twist and squirm, they were helpless, and as the net would be unfurled, another loop held by two other natives would then be slipped over its head and as the other loop was allowed to come free from the bamboo, they would take the animal which was now clear of the net and drop it in the rough cage. With the bars fastened and the animal safe, it was ready to be sent on to the nearest kampong.

This method of course could only be used with the smaller animals. The larger cat animals that were caught in the nets, two leopards and one clouded tiger were so entangled that we put nets and all in the rough cages and then from between the bars, cut enough of the mesh in the net for the animals to free themselves. The larger deer gave us a lot of trouble on account of getting their horns and feet entangled through the meshes and most had to be killed. These we fed to the cat animals, after we had taken our fill. One tapir and calf we got in nets, the other two in pits. The wild boars gave us the most trouble. Whereas the tapirs were timid, the boars were very vicious and could only be put in cages by the same method I used with leopards. With the tigers and leopards caught in set traps, a transportation cage is set close to one end of the trap with two bars raised. 
A chicken or bait of some kind is placed within the cage, then a couple of bars of the trap are loosened and drawn out. If the animal refuses to enter the cage he is prodded with poles until he does, the bars are then slipped into their place and the animal is secured. There is really no danger or excitement in trapping and caging of tigers, or any animal caught in a trap of that kind.

In all I stayed with the Tungku nine weeks and the round-up of animals caught by net and pit, included ninety-two different varieties, not including three tigers, two spotted and one black leopardforty-three cages and sixteen crates. This only includes those specimens in good condition. I do not count the animals that were killed off on account of not being fit to show for zoölogical purposes.

It was my good fortune during my stay with the Tungku to witness a bull fight. Under a covered shed on a raised platform the Sultan with his Court and guests sat, while the natives, five and six deep, either sat on the ground or stood forming a circle of about seventy yards in which the bulls fight.

The bulls belonged to a local breed. They are small in size, but sturdy, well built, very quick in movements, have a small hump on their necks, and short sharp horns. They are trained for fighting from early youth and out in the ring about the age of three, but are at their best at four or five years old. Bulls of as nearly as possible the same 
size and weight are generally matched to fight, and when once the bulls have been let go, the fight continues till one turns tail and leaves the field.

Each bull has three or four men who encourage it to greater efforts and when the fight is over lead it away.

Sometimes one of the bulls declines to fight altogether and rushes away the moment he is faced by his adversary. The victor then performs a strange sort of war dance alone, whirling round and round, tossing his head, bellowing and snorting and finally dashing off in pursuit of the enemy, demoralizing and scattering the crowd of spectators who fall over each other in their efforts to get out of his dangerous path.

Usually there is a fight more or less prolonged and when at last one bull gives way and runs for the field, he is followed, caught and brought back again to face his adversary. If he fights again, well and good, but the second bout rarely lasts any time and the beaten bull again saves himself by flight. That settles the matter as far as backers are concerned and the bets are paid. It very seldom happens that a bull is killed or even seriously injured. As soon as the bulls arrive on the ground, they are inspected at close quarters by the backers, while the setters-on give the last touches to their champion. They take the cover from the points of their horns, squeeze and rub a lemon on their nose and tongue, and tickle their back and sides. 
The bets are made and deposited with the stakeholder. The choice of position is decided by the drawing of one or two blades of grass held in the umpire's hand. The owner who draws the short blade takes the upstream position for his bull, while the other bull faces him from downstream. The setters-on then bring their respective bulls closely up to have a good look at each other, slowly pass about ten yards apart, and then bring them face to face. The leading ropes are suddenly cast off and the bulls dash at each other with fury and meet head on with a resounding thud. In a second their horns are interlocked, each trying by every ruse and device to drive the other back on his haunches or throw him over by main force. A moment later the horns are disengaged to find a new and a better purchase, and first one and then the other will gain a slight advantage and both bulls move this way and that from the center to the sides. The people of the East are seldom supposed to give way to demonstrations expressing emotion, but while a bull fight is on the Malays yell themselves hoarse with shouts of encouragement and approval, while the setters-on half mad with excitement simply dance around the bulls.

The varying tide of the battle carried the bulls to the center of the circle, and the novice which at first contented himself with simply resisting the attacks of his antagonist now made his great effort, pressing irresistibly forward, and bringing 
his great weight so to bear, that at last his adversary was forced back a few inches. Another effort and another, then gathering himself together, he rushed the other back and the latter's hind legs giving way under the pressure, he was thrown on his side and the other was upon him, butting unmercifully with his short, sharp-pointed horns. The old bull was beaten, but gathering himself together he recovered his legs and disappeared amidst a scene of the wildest excitement; men shouting themselves hoarse and otherwise expressing their delight. The excitement did not last more than a few minutes, then everybody quietly discussed what was held to be a great fight. It lasted about twenty minutes. The beaten bull was brought back again but as he declined to face his late adversary, he was led away, the bets were paid, and every one settled down again to wait for the next fight.

On my return from the round-up, for several years I did not venture into the jungle for more than a day or two at a time. My fever and dysentery had become chronic. I realized that I had too often disregarded the warning of the doctors and that, if I had another bad attack of illness, far away from medical attention, I should have to leave the country or might possibly die before I got way. My animal business in Singapore had grown so large that it gave me plenty to do, and I left to my agents the work of collecting. Through my house in Orchard Road passed a 
steady stream of animals, destined for zoölogical gardens all over the world.

Most of the animals went to the various Australian gardens for which I acted as agent. They allowed me to make my shipments f. o. b. Singapore, relieving me of the risks of transportation. In return, I gave them first call on all of my best specimens. When their needs had been supplied I had my choice between shipping to Hagenbeck's agent at Calcutta, shipping to Europe, and selling to the crews of boats that called at Singapore. The offcers and men bought many animals, sharing the cost and eventually sharing the profits if the animals lived to reach Europe. Ariff, by crooked dealing and passing off sickly animals, had almost ruined this business, but it revived rapidly when the word spread that I could be depended upon. Ariff and I had many stormy sessions before I convinced him that my way was the better, and he finally came to handle a large part of the boat trade for me, doing the work of soliciting orders and making deliveries on commission.

I made very few sales directly to America. The trouble and risk of the long voyage were too great, and also there was a twenty-five per cent duty to be paid when the animals were landed. The gamble was large, and, even when the deliveries were safely made, there was little profit. Some of my animals reached America through Hagenbeck, who kept them until they were acclimated and then 
shipped them across the Atlantic. The acclimatization and breeding of animals in captivity is a business in itself.

Hagenbeck approached me several times with the proposition to become his exclusive agent in the Far East, but I preferred to have my own business and sell independently. Both he and Cross of Liverpool kept me busy with orders; and, with the orders from Australia, I found that I had a greater demand that I could meet. Almost every boat that came to Singapore from the districts where animals were captured brought specimens, and I was continually pressing my agents to send more. I traveled constantly throughout the Archipelago, urging the natives to work faster and keeping in touch with the source of my supply. As I have said before, I made few excursions into the jungle, and then only when it was impossible for my agents, who were generally headmen, to leave their kampongs and come to the coast.

Trengganu, with its jungles full of animals, was my favorite territory. I had the valuable privilege of being practically the only white man who could enter that country. In it I passed so much of my time that I finally had a house built there for me. My presence speeded the work of capturing, though I took no part in it except to talk with the headmen when they came to the coast. The Sultan gave me unlimited power in handling the natives, and 
no native who worked for me ever had cause to complain.

Nor had the Sultan himself; for I often found ways of helping him when the treasury was at low ebb. He looked to me to bring him news of the outside world and to interpret the news for him in terms that were understandable. Several hours of each day I spent at the palace, in discussing the affairs of the country with the Sultan and his Prime Minister, Mahommed Yusuf. Yusuf was a tunku běsar (big prince) and was formerly the Sultan of Lingga. He was driven from his country by the Dutch and had sought refuge with his brother, the Sultan of Trengganu. There he lived as an object lesson of what might happen if Europeans were allowed to come into the country.

It was inevitable that Trengganu should eventually be taken over by the British, but the Sultan fought the idea at every turn. He could see in such a possibility nothing but ruin for himself, and he was determined to hold out as long as he lived. In our long talks we discussed every phase of his situation, and I pointed out to him that other sultans had prospered under the British. He was interested in that fact and asked for more information. Finally, it was arranged that Sir Frank Swettenham, who was governor-general of the Straits Settlements, should make a visit to Trengganu. That was the entering wedge. A few years later, an agreement was reached by which the country be- 
came a British protectorate and the Sultan, a prosperous, though nominal, ruler; and the development of this virgin territory began.

As a reward for the advice and assistance I gave him, the Sultan, before Trengganu passed out of his control, made me a present of five different concessions of land, with all mineral and surface rights. Though the concessions, which totaled nine hundred square miles, were rich in tin, the Sultan advised me to let the tin stay where it was and plant rubber. I could see that I had reached the beginning of the end of my career as an animal dealer!

On my return to Singapore after one of my visits to Trengganu, I found a letter from Mr: La Souef, of Melbourne, asking me if I would make a special effort to get a rhinoceros for his zoölogical gardens. He had made the same request the year before, and I had had a standing order with my agents in Trengganu, but nothing had come of it. There was constant good-natured rivalry between $\mathrm{Mr}$. La Souef and his son, who was director of the gardens at Perth, and, as I had provided the son with a rhinoceros, I wanted to do as much for the father. I wrote to him, saying that I should communicate with my agents and that, if they had nothing to report, I would go out myself and see what I could find for him. Accordingly, I sent Ali to Trengganu with the message, telling him to wait there until I arrived.

There seemed to be so little chance that the na- 
tives would capture a good specimen that, after attending to the business at the animal house, I gathered my kit and started northward. At Trengganu I found Ali and some of the headmen waiting for me. Just as I had expected, they had nothing to report. One of them said that he thought I could find a rhinoceros near Rawang.

"Why do you think so?"

"Than," he replied, "there are traces."

"But why haven't your men been digging pits and capturing it?"

He made some reply to the effect that his men were busy planting rice, and I let the matter drop, for I saw that he was unwilling to talk. After the headman had left the house, I questioned Ali. While waiting for me, Ali had drawn the headman out on the subject. It seemed that the natives of the headman's kampong were reluctant to go out hunting the rhinoceros because they had seen the tracks, not only of the beast they were after, but also of beasts they wanted to avoid-a pair of seladangs.

I could understand, then, why they were not anxious to go out rhinoceros hunting, armed with nothing but their knives and muzzle-loading guns; for the seladang is, to my mind, the most dangerous animal on earth. It is the largest and fiercest of all wild cattle; its sense of smell and its vision are keen, and it charges with terrific speed. Except for one baby seladang that died before it reached 
a menagerie, not one has ever been captured alive. A number have been killed and mounted and are to be found in museums.

In meeting seladangs a hunter needs all his skill and courage. They eharge without an instant's warning, breaking through the jungle at incredible speed. Unlike most animals, they do not try to protect themselves by defensive methods, holding the charge until they are cornered; they are instantly on the defensive. The hunter becomes just as much hunted as his quarry; each tries to attack by surprise. It is vitally important in running down seladangs for the hunter to keep his feet clear of vines and creepers, so that he can be free to jump; and also to keep his eye on a tree, which will provide refuge in case he needs it. The only possible way for a hunter to escape the direct charge of a seladang is to fall flat and let it run over him; its neck is so short that, when he is prostrate, it cannot reach him with its horns. Then, if the hoofs have not knocked him unconscious or broken his bones, he can jump up, before the seladang can check itself, and run for a tree. For the man once caught on the beast's horns, there is no escape; it tosses a victim time after time and then tramples him.

I had never met a seladang-and I must admit that I was not especially anxious to meet one-but I had no doubt of my ability to handle it if the emergency arose, and so I determined to go to Rawang 
for the rhinoceros. I had confidence in my express rifle and $I$ knew that the natives would not refuse to accompany me. It would be useless to force them, of course, for they would be constantly on the verge of a panic. I sent Ali to talk with the headman and bring him to my house.

That afternoon a large part of the village across the river from my house burned to the ground. While I was sitting on my veranda, waiting for Ali to return with the headman, I saw smoke arising from one of the houses in the Chinese section. A moment later, flames appeared, the alarm was given and the village was in an uproar. The flames leaped from house to house, running down the principal street, where all the godowns were located. I went across the river to watch the excitement and see what I could do to help. The natives were wild: rushing about, falling over one another and going crazy. I stood at one side, quite out of the way, for a native in such a condition is a dangerous person; the least word may send him âmok and start him slashing with his kris. Not one native thought about the safety of his women and children. On the contrary, he pushed women and children out of the way and walked on them in the excitement of rescuing the one possession that a Malay values-his kris. Men dashed into burning houses and emerged triumphantly, scorched but waving their krises over their heads.

One of the tunkus managed to organize in the 
midst of the turmoil, what passed as a water-chain. The natives grabbed buckets and ran to the river, returning at full speed, waving their buckets and getting in one another's way. I doubt if a single bucket reached the fire with more than a cupful of water in it. It was so funny that I had to hide where no one could see me laughing. I heard later that the old Sultan laughed until he was weak.

He feared only that the wind might change and bring the fire on his palace; and he sent Mahommed Yusuf to find me and ask my advice. Yusuf and I decided that, if the wind showed any signs of changing, it would be best to tear down some of the village, to make a protecting strip. I went back across the river to my house for dynamite to aid in the work of demolition. However, the wind did not change, and, in exactly a hundred minutes after I saw the first smoke, the fire had run its course.

In that time, a hundred and twenty-five houses had burned to the ground, but no lives had been lost. And so it was not a serious calamity, since house-building in that section of the country is a simple matter. The Malays thought it a great joke that the stores that were destroyed belonged to the Chinese; for the Chinese were always cheating them. By the time evening came, it was as if the fire had been arranged to give the population an exciting and amusing holiday.

That night, Ali, after indulging in some eloquence on the subject of my express rifle, brought 
the headman to me. Until late, we three sat on the veranda of my house, talking about the rhinoceros hunt and the chances of encountering a seladang. At last the headman said that he would think about the matter and give me his answer the next day.

I spent the morning with the Sultan, who was still laughing about the water-chain at the fire, and I returned to my house early in the afternoon. The headman and Ali were waiting for me. It was decided without further delay that we should go to Rawang to capture the rhinoceros.

The natives at the headman's kampong were not over-anxious to take part in the hunt, and we spent several days there, waiting for them to make up their minds. It was useless to urge them, and to force them, as I had the power to do, would have been out of the question. It was a matter of waiting and working up their enthusiasm. Ali talked with them, cleaning my rifle and telling them about the "magic" I had performed. Then, after they showed signs of being properly impressed, I took my gun and began shooting explosive bullets into the trunks of trees. They stood about, wide-eyed, watching the bullets tear great holes in the trees. One evening, two days after our arrival at the kampong, the headman came with the word that his men had decided that they would like to go rhinoceros-hunting with me. "But I can take only ten," I replied. "I want you to come and I will let you select nine others-your best men." Now that 
the desire to go rhinoceros-hunting was alive in the village, I knew that the selection of nine men would make rivalry keen, and that those who were selected would be proud to go.

Shortly after dawn the next morning we left the kampong and struck out toward the spot where the rhinoceros had been located. We kept up a good pace during the day, following the trails through the jungle and cutting our path. Three days later we came upon signs of the rhinoceros and began tracking the spoor.

At sundown, as we were approaching an opening where we intended to make camp, we heard a crash in the jungle. "Seladangs!" screamed the Malays.

The men dropped everything and jumped for the trees just as two seladangs came charging down upon us. Ali, who was carrying my rifle and who had become separated from me when the men rushed for the trees, started toward me. Gauging the distance, I saw that he could not make it and I yelled to him to save himself. I jumped backward and made for a tree; then, as I pulled myself up, I. saw the bull seladang catch Ali on his horns and toss him. I dropped to the ground again, horrified; I wanted to get my rifle and I forgot about the other animal.

The cow seladang charged, and I barely had time to get behind the tree. Unconsciously I had drawn my parang, and, as the great chocolate- 
colored beast plunged past me, I slashed. The blade hamstrung her, and she plunged, bellowing, into the jungle. Then the bull, instead of catching Ali's body on his horns, allowed it to fall to the ground and turned toward me. I swung up into the branches of the tree, just out of his reach, and slashed downward as he charged. I failed to hit him and I narrowly escaped falling.

We could hear the cow bellowing furiously and dragging herself away through the jungle. She did not return. The bull charged back again and stood beneath me, pawing the ground and bellowing. Then he turned and attacked Ali's body, trampling upon it, time after time, until every bone was broken.

Each time the bull returned to the tree, I fired downward at him with my revolver, but I might just as well have used a pop-gun-the little bullets had no effect. One dynamite cartridge would have ended him, but my rifle lay on the ground five yards away. Night came on, but the seladang did not leave. I remained poised throughout the night, waiting for a chance to jump down and run for the rifle. Our thirst became terrible, and there was little consolation in the thought that the seladang was probably quite as thirsty as we were. But there was some chance that he would leave us for a few moments to find water, and I needed only a moment to get the rifle and climb back into my tree. 
Ants and mosquitoes swarmed over us. Trying to find some protection against them, we wrapped our hands and faces in sârongs. But we were as helpless against insects as against seladangs.

Morning came and wore away to noon, and still the beast stayed by his post. Then the fever began to hit me and my head throbbed. I propped myself up against the trunk of the tree, saving all my strength until the moment when I should need it most.

Ali's body was unrecognizable; he had been gored repeatedly in the tossing and now he was simply a mass of torn, trampled flesh. The beast returned to it again and again to sniff and paw, and the sight made me weak and ill.

The ten natives were scattered through the trees near me and we talked back and forth. They, of course, depended upon me and my "magic" to save them, and I, with the fever burning more fiercely every minute, realized that something must be done immediately. My thirst was becoming unendurable and my strength was leaving me rapidly. I called to the men to join me in my tree, and they swung from limb to limb until we were together. The seladang took up his position beneath us, bellowing and pawing.

I counted the arms in the party; we had, besides our parangs, four spears and three krises. With the parangs we cut stout branches; then we tore our sârongs into strips and bound the krises to 
the poles. As was usual in the Archipelago, especially in the inland districts, the spears and krises were poisoned, and our only hope of victory lay in that fact. I knew that the poison would kill a man in a few minutes and I had seen smaller animals die of it, but I did not know what effect it would have on so large and powerful a brute as a seladang.

Next we gathered leaves and stuffed a sack, made from a sârong, full of them, and tied it with a string, so that we could dangle it in front of the beast. Then three of us armed with the krises took positions so that we should be above the seladang when he charged, and we lowered the sack. He snorted and drew back; then he put his strength into his legs and lunged forward. I drove downward with my kris, tearing a wound in his back near the hump; he whirled and charged again, and this time one of the natives blinded him in one eye.

He withdrew a few yards, snorting, bellowing and pawing. He turned again on the body of poor $\mathrm{Ali}$, as if to vent his anger on it. Presently we lured him back with the bundle of leaves, and he charged again. I scored another cut near his hump.

This charging and jabbing went on for fully an hour, and we seemed no nearer success than when we started. It was impossible to get in a deathstroke, and the poison apparently was having no effect upon him. In any event, I thought, we were winding him, and, if we could last out another 


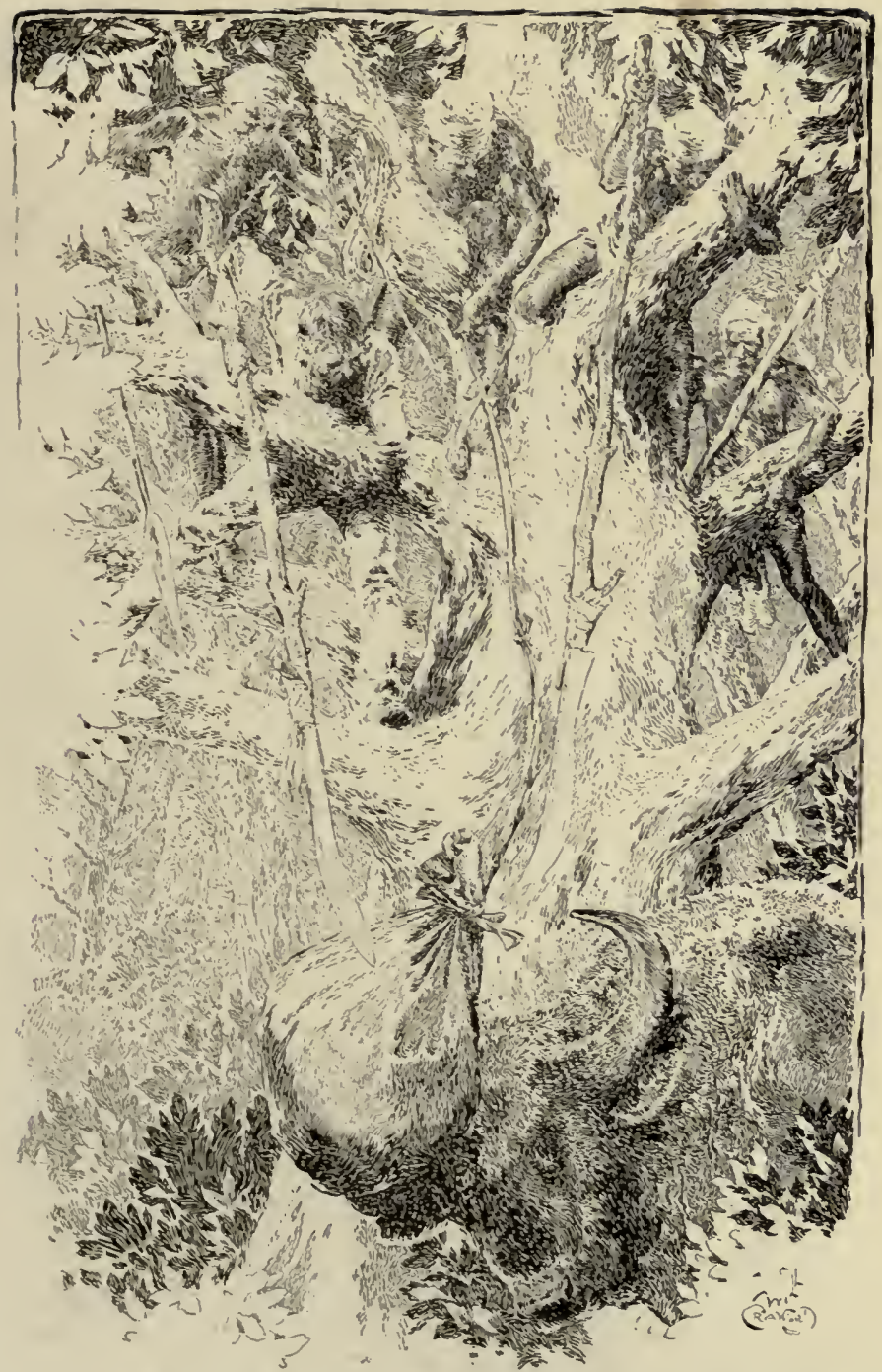

"Then three of us armed with krises took positions so that we should be above the seladang when he charged, and we lowered the sack. He snorted and drew back." 

night, he would have to seek water. But there was another danger-one of the natives, crazed by thirst and excitement, might run âmok there in the tree. I planned, if we were forced to remain in the tree through the night, to take charge, diplomatically, of the krises and spears. I regretted having spent all the ammunition for my revolver on that useless fusillade the day before.

The game resolved itself into an attempt to pierce the seladang's sound eye; we lured him back, time after time, but could not drive a kris to the mark. Evening was approaching, and I thought the battle was over for the day. The seladang stood near by, ignoring, for the moment, the sack we were dangling. Blood was flowing from a dozen wounds. When he took a step forward, we cried out in surprise. He was weakening! He almost tottered away, as if he had forgotten about us.

Even though he had routed us completely, treed us and kept us treed and killed my good friend and assistant, Ali, I felt sorry for the beast, as I sat there watching him. He had put up a magnificent fight, and, half dead, he would muster his remaining strength and charge us again if we dared set foot on the ground. It was his victory until the moment he died.

His head drooped lower; then he went down on his fore knees, bellowing weakly. Presently his hind quarters slumped down, and blood began to flow from his mouth. 
I dropped from the tree and walked forward cautiously to the spot where my rifle had fallen; then, armed, I stood watching him in the throes of death. None of the Malays had followed me, and, when I told them to come down, they refused. Finally, to convince them that there was no danger, I put a 50-I IO explosive bullet behind the beast's shoulder.

We dug a grave for Ali and buried him; then we gathered our material and started back for the kampong. My fever was so bad that the medicine in my kit did me little good; for hours at a time, I was unconscious and had to be carried. At the kampong, I rested for several days, gathering strength to make the trip to the coast.

When I went to see the Sultan at Trengganu, before taking the boat to Singapore, he regarded me severely and said: "Tûan, why have I given you big concessions in land? Is it because I want you to go out and kill yourself in capturing animals?" He seemed satisfied when I told him that my days as an animal capturer were over, and that, after a trip home, I should return to Trengganu, to make my fortune in more peaceful ways.

At Singapore, I saw my doctor, who looked me over and told me that any more escapades in the jungle would be the last of me. He ordered me to leave the country at once and I took passage on a steamer sailing the next week.

Then I hurried off to Palembang, where I had 
spent my first months among the Malays. It was Ali's home, and I was in duty bound to take his $\mathrm{kris}$ back for him. The old hadji received me affectionately and heard the story of his nephew's death.

"He died bravely, tûan?" he asked.

"Yes, and in the faith."

The hadji nodded; that was what he wanted to know-whether or not Ali died a good Mahommedan.

"On what day did he die, tûan?"

I could not remember what day it was, but I knew what the old man hoped and I answered, "Friday."

That meant that Ali was certain of Paradise.

I said good-by to the hadji and went back to Singapore to catch my boat. The fever was still racking my body, but, when I saw the Red Sea behind us once more, I knew that luck had been with me. 






\section{University of California}

SOUTHERN REGIONAL LIBRARY FACILITY 305 De Neve Drive - Parking Lot 17 - Box 951388

LOS ANGELES, CALIFORNIA 90095-1388

Return this material to the library from which it was borrowed. 
